\title{
2019
}

Universitas

Muhammadiyah Sidoarjo

Santi Rahma Dewi, SE, M.Ak 


\section{BUKU AJAR \\ AKUNTANSI BIAYA}

Penulis :

Santi Rahma Dewi, SE., M.Ak

ISBN :

\section{Editor :}

Santi Rahma Dewi, SE, M.Ak

Design Sampul dan Tata Letak :

Mochamad Nashrullah, S.Pd

Penerbit :

UMSIDA Press

Redaksi :

Universitas Muhammadiyah Sidoarjo

Jl. Mojopahit No 666B

Sidoarjo, JawaTImur

Cetakan pertama, Agustus 2019 
(C) Hak cipta dilindungi undang-undang

Dilarang memperbanyak karyatulis ini dengan suatu apapun tanpa ijin tertulis dari penerbit.

\section{KATA PENGANTAR}

Puji syukur atas berkat rahmat dan hidayah yang telah dilimpahkan oleh Allah SWT, sehingga penulis dapat menyelesaikan Buku Ajar Akuntansi Biaya ini dengan baik. Akuntansi biaya merupakan sistem informasi yang hasilnya berfungsi sebagai penyedia informasi khususnya informasi mengenai biaya yang dapat membantu pihak manajemen dalam melakukan perencanaan, pengendalian serta pengambilan keputusan.

Dalam upaya memberikan pemahaman yang lebih baik atas akuntansi biaya, buku ini memberikan bahasan yang cukup luas sehingga dapat memberikan penjelasan terkait ruang lingkup akuntansi biaya. Untuk mendukung capaian pemahaman yang mendalam dalam buku ini juga menyajikan soal-soal latihan agar dapat memberikan ilustrasi yang memadai.

Akuntansi Biaya secara garis besar terdiri dari konsep dasar akuntansi biaya, peranan akuntansi biaya, sistem perhitungan biaya. Dalam sistem perhitungan biaya dibagi menjadi dua kelompok, yaitu sistem biaya berdasarkan pesanan dan sistem biaya berdasarkan proses.Dalam pokok bahasan akhir disajikan mengenai jenis-jenis biaya serta metode perhitungannya, yaitu biaya bahan, biaya tenaga kerja, biaya overhead pabrik.

Dengan terbitnya buku ajar ini, penulis mengucapkan banyak terima kasih kepada semua pihak. Khususnya mahasiswa, rekan sejawat, seluruh civitas akademika Universitas Muhammadiyah 
Sidoarjo, dan pihak-pihak lain yang telah membantu hingga terbitnya buku ini. Dan semoga buku ajar ini dapat bermanfaat. Aamiin.

Sidoarjo, 2 Juli 2019

Penulis 


\section{DAFTAR ISI}

KATA PENGANTAR

DAFTAR ISI

BAB 1 KONSEP DASAR DAN PERANAN AKUNTANSI BIAYA..............1

Peran Akuntansi Biaya.......................................................

Definisi Akuntansi Biaya..................................................4

Pemilihan Berbagai Alternatif...........................................6

Soal...............................................................................

BAB 2 KONSEP BIAYA DAN SISTEM INFORMASI AKUNTANSI BIAYA.8

Objek Biaya Tetap........................................................ 8

Penelusuran Biaya ke Objek Biaya.....................................9

Sistem Informasi Akuntansi Biaya....................................

Klasifikasi Biaya..................................................................

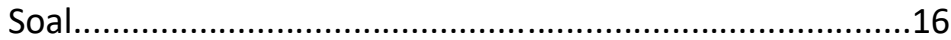

BAB 3 PERILAKU BIAYA..................................................18

Klasifikasi Biaya........................................................18

Metode Tinggi Rendah................................................21

Metode Kuadrat Terkecil.................................................28

Metode Kuadrat Terkecil Untuk Beberapa Variabel

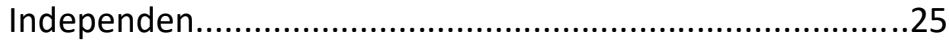

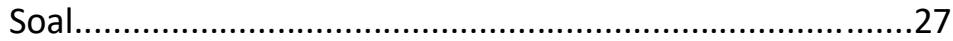

BAB 4 SISTEM PERHITUNGAN AKUMULASI BIAYA........................29

Laporan Hasil Operasi........................................................30

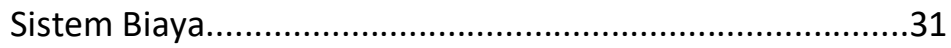

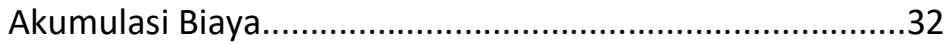

Sistem Perhitungan Biaya Berdasarkan Pesanan.................33

Sistem Perhitungan Biaya Berdasarkan Proses....................34

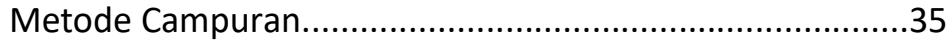

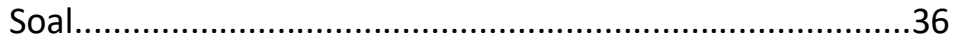


BAB 5 SISTEM PERHITUNGAN BIAYA BERDASARKAN PESANAN.....39

Pengertian dan Karakteristik Biaya Produk Berdasarkan

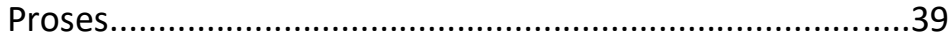

Akuntansi Bahan Baku....................................................41

Akuntansi Tenaga Kerja..................................................44

Akuntansi Biaya Overhead Pabrik........................................46

Akuntansi Barang Jadi dan Produk Dijual...........................49

Sistem Perhitungan Berdasarkan Pesanan Untuk Produk

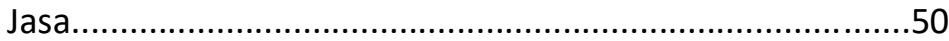

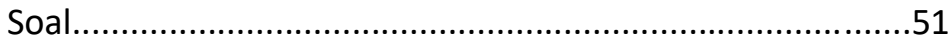

BAB 6 SISTEM PERHITUNGAN BIAYA BERDASARKAN PROSES........53

Akumulasi Biaya Proses.................................................53

Perhitungan Biaya Departemen.......................................54

Aliran Produksi................................................................55

Akuntansi Biaya Bahan Baku, Tenaga Kerja dan

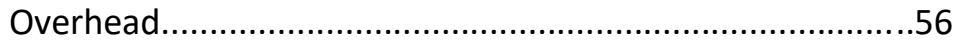

Laporan Biaya Produksi....................................................58

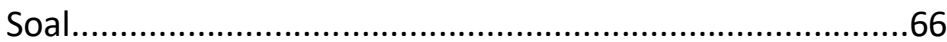

BAB 7 SISTEM PERHITUNGAN ALOKASI BIAYA PRODUK

SAMPINGAN DAN PRODUK GABUNGAN..................................68

Pengertian Produk Sampingan Dan Produk Gabungan........68

Karakteristik Produk Sampingan dan Produk Gabungan......68

Kendala Perhitungan Biaya Produk Sampingan dan Produk

Gabungan

Metode Alokasi Biaya Produksi Bersama ke Produk

Gabungan.....

Analisis Biaya Produksi Bersama untuk Pengambilan Keputusan Manajerial dan Analisis Profitabilitas................74 Soal. . .76

BAB 8 BAHAN BAKU................................................................77

Perolehan dan Penggunaan Bahan Baku...........................77 
Pembelian Bahan Baku....................................................78

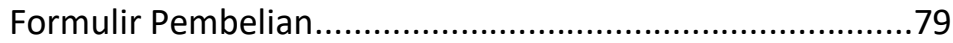

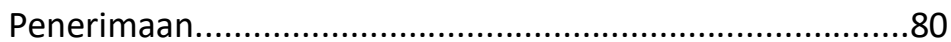

Biaya Perolehan Bahan Baku..........................................82

Penyimpanan dan Penggunaan Bahan Baku........................84

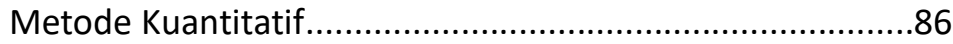

Merencanakan Kebutuhan Bahan Baku............................86

Merencanakan Kebutuhan Bahan Baku..............................86

Menentukan Waktu Pemesanan.......................................87

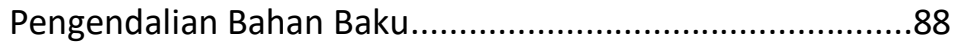

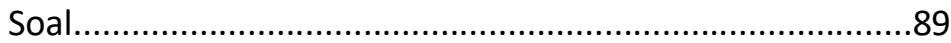

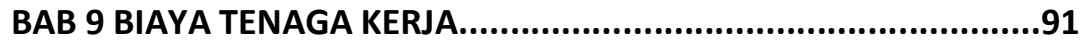

Produktivitas dan Biaya Tenaga Kerja................................91

Perencanaan Produktivitas................................................92

Pengukuran produktivitas................................................92

Dampak Ekonomi dari Penerapan Produktivitas..................93

Peningkatan Produktivitas untuk Manajemen Sumber Daya

Manusia yang lebih Berkembang....................................93

Rencana Pemberian Insentif............................................94

Standar Waktu Teori Kurva Belajar.....................................95

Akuntansi untuk Biaya Tenaga Kerja dan Pengendalian.......96

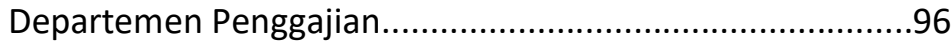

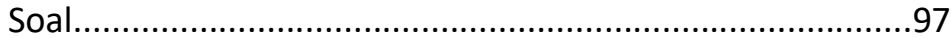

BAB 10 BIAYA OVERHEAD PABRIK : PENENTUAN TARIF

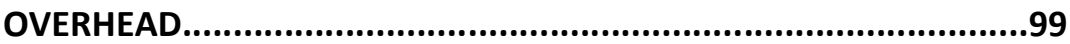

Karakteristik Overhead Pabrik..........................................99

Penggunaan Tarif Biaya Overhead yang Telah Ditentukan Sebelumnya..................................................................100

Faktor-faktor Dalam Pertimbangan Pemilihan Tarif Biaya

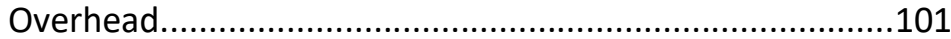

Pemilihan Tingkat Aktivitas...........................................104

Biaya Overhead Dibebankan Terlalu Tinggi atau Terlalu

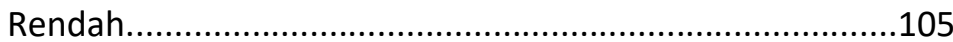

Pembebanan Biaya Overhead.........................................106 


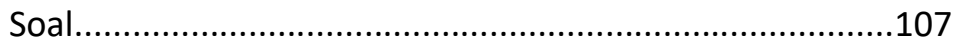

DAFTAR PUSTAKA 


\section{BAB 1}

\section{KONSEP DASAR DAN PERAN AKUNTANSI BIAYA}

Dalam lingkungan akuntansi biaya dapat menguraikan prespektif eksternal dan internal dari sebuah pelaporan dalam suatu organisasi. Dimana dalam sebuah organisasi, akuntansi biaya yang disajikan merupakan bagian dari fungsi manajemen, serta peran dari kontroler. Sedangkan dalam lingkungan eksternal adanya suatu ekspektasi etika, pergerakan sertifikasi serta pengaruh lainnya yang datang dari pihak swasta maupun pemerintah.

Organisasi dalam melaksanakan operasionalnya terdapat pihak manajemen yang mewujudkan tujuan organisasi. Manajemen sendiri terdapat tiga kelompok, yaitu :

1. Manajemen operasi, terdiri dari penyelia.

2. Manajemen tingkat menengah, yaitu manajer divisi, manajemer cabang.

3. Manajemen eksekutif, terdiri dari presiden, wakil presiden yang bertanggung jawab atas pembelian, teknik, manufaktur, pemasaran, keuangan dan akuntansi.

Manajemen dalam operasionalnya terdiri dari banyak aktivitas, dari perencanaan, pelaksanaan, pengendalian serta evaluasi dimana siklus tersebut merupakan aktivitas pengambilan keputusan, memberikan perintah, menetapkan kebijakan, menyediakan tugas dan imbalan serta memperkerjakan orang untuk melaksanakan kebijakan.

Perencanaan yang merupakan konstruksi suatu program operasional secara terperinci, adalah proses dalam merasakan bagaimana adanya kesempatan dan juga ancaman dari pihak eksternal. Dengan perencanaan ini mengidentifikasi karakteristik 
perusahaan, kebijakan dari tujuan utamanya serta penentuan langkah-langkah dalam mewujudkan tujuan perusahaan. Untuk dapat menentukan perencanaan yang baik harus didasarkan atas perencanaan yang efektif dari hasil analisis fakta yang ada serta memerlukan cara berfikir yang imajinatif, dan berorientasi pada masa depan.

Untuk mengidentifikasikan jenis-jenis rencana dalam bisnis, ada tiga. Yang pertama adalah Rencana Strategik yang merupakan rencana yang diformulasikan dan dirumuskan di tingkat manajemen tertinggi karena memerlukan pandangan yang luas dan menyeluruh atas perusahaan dan lingkungannya. Kedua adalah Rencana jangka pendek yang merupakan anggaran, yang disusun dengan terperinci sehingga akan memungkinkan disusunnya laporan keuangan atas kinerja perusahaan dalam periode bulanan, kuartalan dan tahunan. Ketiga adalah Rencana Jangka Panjang yang sering disebut dengan anggaran jangka panjang dengan periode yang cukup panjang antara tiga tahun hingga lima tahun ke depan.

Dengan adanya rencana tersebut maka suatu entitas bisnis akan melaksanakan perencanaan yang telah diformulasikan oleh pihak manajemen. Sebelum adanya pelaksanaan diperlukan adanya Pengorganisasian yang merupakan penetapan kerangka kerja bagaimana aktivitas-aktivitas akan dilakukan. Pengorganisasian ini merupakan sistematika atas beberapa kegiatan yang saling berkaitan dan bergantung. Tujuan pengorganisasian ini adalah penentuan dan pembagian kerja yang efektif yang merupakan hal penting dalam pencapaian tujuan perusahaan.

Pengendalian merupakan usaha manajemen dalam mencapai tujuan dengan melaksanakan monitoring dengan mengumpulkan 
informasi baik finansial maupun aktivitas secara periodik sebagai dasar pengambilan keputusan atas tindakan pengendalian.

Dari siklus perencanaan, pengorganisasian, pelaksanaan hingga pengendalian diperlukan penugasan fungsi-fungsi tersebut kepada banyak orang dalam perusahaan, sehingga aktivitas yang perlu mendapatkan tindakan korektif mudah dikendalikan. Begitu pula dengan laporan yang dihasilkan akan lebih mudah untuk di monitoring. Sehingga dibutuhkan pembagian wewenang dan tanggung jawab untuk mewujudkan akuntabilitas. Wewenang merupakan kekuasaan untuk mengarahkan orang lain agar dapat melakukan maupun tidak melakukan suatu aktivitas, yang mempunyai fungsi sebagai kekuatan dalam menyatukan organisasi. Wewenang ini berasal dari manajemen eksekutif yang mendelegasikan wewenang tersebut ke tingkat yang lebih rendah.Walaupun ada pendelegasian tanggung jawab tetap berada pada manajer. Tanggung jawab adalah hal yang sangat berhubungan dengan wewenang, dimana tanggung jawab merupakan hubungan antara atasan dan bawahan. Akan tetapi pada dasarnya tanggung jawab atasan terhadap hasil kinerja bawahan. Selanjutnya akuntabilitas merupakan salah satu bagian dari tanggung jawab, hasil akuntabilitas perusahaan adalah pelaporan hasil kepada wewenang yang lebih tinggi.

Berdasarkan tanggung jawab dan wewenang yang telah dibentuk dan disusun dalam suatu organisasi maka akan memunculkan urutan tanggung jawab dan wewenang dalam suatu organisasi yang tergambarkan dalam bagan organisasi. Bagan organisasi ini yang menunjukkan wewenang dan tanggung jawab mulai posisi manajemen utama hingga pana lini staf. Pengembangan organisasi yang terorganisir dengan sistem akuntansi biaya dan anggaran yang akan mengarah pada pendekatan akuntansi dan 
pelaporan sebagai akuntansi pertanggung jawaban (responsibility accounting).

Dalam bagan organisasi terdiri dari beberapa fungsi lini, yaitu fungsi sumber daya dan fungsi proses. Dari dua fungsi tersebut merupakan penggabungan dari proses pengorganisasian sehingga akan terdeteksi sistem akuntansi biaya dan menghasilkan laporan akuntansi biaya.

\section{Peran Akuntansi Biaya}

Pada masa lampau akuntansi biaya merupakan metode perhitungan nilai persediaan yang hasilnya dilaporkan dalam neraca dan laporan harga pokok penjualan yang disajikan dalam laporan laba rugi. Dengan keterbatasan ini yang membuat informasi yang dihasilkan oleh akuntansi biaya hanya berupa data biaya produk yang dipergunakan untuk pemenuhan laporan kepada eksternal. Seiring dengan perkembangan di masa sekarang data informasi yang dihasilkan oleh akuntansi biaya tidak hanya dibutuhkan oleh akuntansi keuangan dalam pelaporan keuangan, akan tetapi juga dipakai sebagai dasar manajemen dalam aktivitas perencanaan, pengendalian, perbaikan kualitas dan efisiensi, serta pengambilan keputusan baik yang rutin maupun strategis.

Definisi Akuntansi Biaya adalah mengukur, menganalisis, dan melaporkan informasi keuangan dan non keuangan yang terkait dengan biaya perolehan atau penggunaan sumber daya organisasi. Tugas-tugas dari akuntansi biaya adalah sebagai berikut:

a. Membuat dan melaksanakan rencana dan anggaran untuk operasi dalam kondisi-kondisi kompetitif. 
b. Menetapkan metode perhitungan biaya yang memungkinkan pengendalian aktivitas, mengurangi biaya dan memperbaiki kualitas.

c. Mengendalikan kualitas fisik dari persediaan dan menentukan biaya dari setiap produk dan jasa yang dihaasilkan.

d. Menentukan biaya dan laba perusahaan untuk satu tahun periode akuntansi atau untuk periode lain yang lebih pendek.

e. Memilih di antara dua atau lebih alternatif jangka pendek atau jangka panjang yang dapat mengubah pendapatan atau biaya.

Dari tugas-tugas akuntansi biaya yang ada maka perusahaan dapat merencanakan dan menentukan:

Anggaran merupakan pernyataan yang diperhitungkan dan tertulis dari rencana manajemen. Anggaran ini akan dapat dilaksanakan dengan adanya koordinasi dari pekerja, kebijakan sebagai dasar pelaksanaan tujuan organisasi. Anggaran sangat berperan dalam mempengaruhi perilaku penyediaan data yang dibutuhkan perencanaan dan pengendalian bagi manajemen, didalamnya termasuk menetapkan cita-cita, menginformasikan kepada tiap individu mengenai apa yang harus diberikan untuk pencapaian cita-cita organisasi, memotivasi kinerja sesuai dengan yang diinginkan, evaluasi kinerja, memberikan saran kapan tindakan korektif akan dilakukan.

Pengendalian Biaya merupakan tanggung jawab yang harus diberikan kepada tiap individu yang juga bertanggung jawab untuk menganggarkan dibawah kendali manajemen. Dalam 
membantu mengendalikan biaya, akuntan memerlukan informasi dari proses sebelumnya yang dipergunakan sebagai jumlah biaya yang telah ditetapkan atau yang disebut sebagai biaya standar (standard cost). Selain biaya standar yang dipergunakan sebagai pengendali, terdapat aspek penting lainnya yaitu melakukan identifikasi terhadap aktivitas-aktivitas yang memberikan nilai tambah terhadap suatu produk dan aktivitas-aktivitas yang tidak memberikan nilai tambah (non value added activities). Indentifikasi aktivitas-aktivitas ini akan mampu memberikan informasi bagi efisiensi dan efektifitas operasional perusahaan.

Penetapan Harga yang di telah ditetapkan dalam kebijakan manajemen sebaiknya dapat dipergunakan dalam jangka panjang, sehingga jika perusahaan dalam kondisi yang sulit akan tetap bertahan serta jika ada persaingan harga dari kompetitor dalam suatu waktu dengan produk senilai.

Penentuan Laba dalam setiap periode yang disesuaikan dengan tujuan perusahaan memakai perhitungan akuntansi biaya dengan memperhitungkan biaya output terhadap produk yang dijal dibandingkan dengan biaya-biaya lain dan pendapatan sebagai dasar informasi menghitung laba. Proses penghitungan laba ini sangat berkaitan dengan hasil identifikasi biaya jangka panjang dan jangka pendek, serta biaya tetap dan biaya variabel.

Perhitungan biaya ini dikaitkan dengan biaya manufaktur variabel yang dibebankan kepada unit yang diproduksi selanjutnya dikaitkan dengan nilai pendapatan saat produk tersebut dijual. Terdapat beberapa alternatif perhitungan biaya dengan mengaitkan total biaya tetap disebut dengan perhitungan biaya langsung (direct costing) atau perhitungan 
biaya variabel (variable costing. Kemudian mengaitkan sebagian atau seluruh biaya manufaktur sebagai bagian dari nilai harga pokok penjualan disebut dengan perhitungan biaya absorpsi penuh (full absorption costing).

Pemilihan dari Berbagai Alternatif yang diperlukan perusahaan dalam mengambil keputusan, menggunakan informai dari akuntansi biaya yang mengaitkan pendapatan dan biaya yang berbeda yang dihasilkan oleh tindakan-tindakan alternatif. Dengan adanya informasi ini manajemen dapat membuat keputusan jangka pendek dan jangka panjang saat perusahaan memasuki pangsa pasar baru, pengembangan produk maupun diversifikaasi produk, menghentikan suatu produk maupun departemen, membeli atau membuat sendiri komponen untuk suatu produk, maupun sewa guna usaha peralatan.

Dalam memilih alternatif manajemen mengambil keputusan berdasarkan informasi akuntansi biaya untuk menambah produk baru ataupun menghentikan produk yang telah ada sangatlah penting demi keberhasilan perusahaan dalam berkompetisi. Sehingga informasi biaya sangat penting peranannya dalam mengidentifikasi, mengevaluasi, dan memilih strategi bagi organisasi.

Teknologi manufaktur telah menjadi semkin berembang dewasa ini yang mengakibatkan proses yang bersifat intensif modal, dimana dengan adanya otomatisasi pabrik dan bahkan dengan sistem yang terkomputersasi bahkan dengan mesinmesin yang dikendalikan dengan robot. Penggunaan teknologi 
merupakan solusi yang mahal dan menimbulkan banyak masalah walaupun juga memberikan kentungan lebih besar bagi perusahaan. Teknologi mengubah karakteristik biaya yang menghasilkan contohnya tingkat persediaan yang lebih sedikit, penggunaan tenaga kerja lebih sedikit, sebaliknya dengan biaya tetap yang cukup tinggi. Sehingga membutuhan keterlibatan dan motivasi karyawan dalam langkah pertama pelaksanaan otomatisasi.

\section{Soal Diskusi}

1. Bagaimanakah definisi dari konsep perencanaan dan pengendalian yang saling berhubungan satu dengan lainnya sehingga memberikan kontribusi terhadap kemajuan dalam pencapaian tujuan.

2. Definisikan peran penting anggaran dalam perencanaan biaya.

3. Bagaimanakah penentuan laba yang harus memperhatikan beberapa alternatif dalam penentuan biaya manufaktur?

4. Apakah yang harus diperhatikan dalam pelaksanaan otomatisasi dalam proses di perusahaan. 


\section{BAB 2}

\section{KONSEP BIAYA DAN SISTEM}

\section{INFORMASI AKUNTANSI BIAYA}

Konsep biaya merupakan nilai tukar, pengeluaran, atau pengorbanan yang dilakukan untuk mendapatkan manfaat adalah definisi akuntan. Biaya (cost) seringkali disamakan dengan beban (expense) sehingga perlu dibedakan dimana Biaya (cost) adalah suatu pengorbanan sumber ekonomi yang diukur dalam satuan uang, untuk mendapatkan barang atau jasa yang diharapkan akan memberikan manfaat baik sekarang maupun yang akan datang. Sedangkan beban (expense) adalah suatu pengorbanan sumber ekonomu yang ditujukan untuk memproleh pendapatan pada periode dimana beban itu terjadi atau merupakan bagian dari harga perolehan yang dibebankan dalam rangka memperoleh penghasilan.

Istilah biaya akan lebih spesifik jika digabungkan dengan suatu petunjuk tertentu, seperti biaya langsung, biaya konversi, biaya variabel, biaya tetap, biaya tak langsung, biaya terkendali, biaya bersama, estimasi biaya, biaya standar, dan lain sebagainya. Biaya tersebut akan dicatat dan diakumulasikan pada saat manajemen melakukan pembebanan biaya ke dalam persediaan, penyusunan laporan keuangan, merencanakan dan mengendalikan biaya, menetapkan pilihan dari beberapa alternatif, evaluasi kinerja, membuat rencana dan memilih keputusan strategis. Sehingga dapat disimpulkan bahwa setiap beban adalah biaya akan tetapi tidak setiap biaya adalah beban. 


\section{Objek Biaya}

Objek biaya (cost object) , atau tujuan biaya (cost objective) merupakan suatu item ataupun aktivitas yang biayanya diakumulasikan dan diukur. Aktivitas- aktivitas tersebut adalah produk, Pesanan pelanggan, Proses, Departemen, Divisi, Proyek, Kontrak, Unit Produk, Tujuan Strategis.

Dengan beragamnya kebutuhan dalam menemukan, merencanakan dan mengendalikan biaya, memunculkan konsep dari objek biaya yang merupakan suatu terobosan ide dari bidang akuntansi. Akuntansi biaya bersifat multidimensional. Karena adanya keberagaman kebutuhan dari desain sistem akuntansi biaya dan implementasinya yang perlu disesuaikan dengan kebutuhan yang beragam sesuai dengan kepentingan departemen, letak geografis, fungsinya, dan lain sebagainya menjadi tanggung jawab dari manajemen dalam perencanaan dan pengendalian biaya.

\section{Penelusuran Biaya ke Objek Biaya}

Setelah pemilihan objek biaya, maka kemampuan pengukuran biaya sangat bergantung pada kemampuan untuk menelusuri biaya ke objek biaya. Kemampuan penelusuran objek biaya untuk dapat menentukan seberapa objektif, handal dan bernilainya ukuran biaya yang dihasilkan, dan seberapa pengaruhnya terhadap keyakinan pengambil keputusan dalam memahami dan mengandalkan ukuran biaya tersebut sebagai dasar untuk membuat prediksi dan mengambil keputusan.

Penelurusan biaya ke objek biaya agar lebih mudah adalah dengan memberikan label biaya langsung dan biaya tak langsung, akan tetapi sesungguhnya penelusuran sangat bervariasi tingkatannya. Metode lain penelusuran biaya ke objek biaya adalah 
dengan penelusuran langsung dan penelusuran penggerak. Penelusuran langsungmerupakan suatu proses pengidentifikasian dan pembebanan biaya yang berkaitan secara khusus dan fisik dengan suatu objek. Penelusuran penggerak merupakan proses pengidentifikasian dan pembebanan biaya yang menggunakan penggerak sebagai dasar pembebanan biaya ke objek biaya. Sedangkan penggerak adalah faktor penyebab yang dapat diamati dan menjadi dasar mengukur konsumsi sumber daya objek biaya.

\section{Sistem Informasi Akuntansi Biaya}

Sistem informasi akuntansi biaya akan menghasilkan informasi biaya yang sistematis dan komparatif dengan tujuan untuk :

a. Menetapkan target laba

b. Menetapkan target departemen

c. Mengevaluasi efektifitas rencana

d. Menunjukkan keberhasilan/ kegagalan

e. Mengidentifikasi dan memilih strategi

f. Memutuskan penyesuaian dan perbaikan organisasi

Sistem informasi akuntansi biaya harus terintegrasi dan terkoordinasi untuk menyediakan informasi yang dibutuhkan manajemen, serta mengkomunikasikan dengan segera dalam bentuk yang mudah dipahami oleh setiap pengguna informasi. Data akuntansi yang diakumulasikan dalam berbagai bentuk, metode dan sistem karena sangat beragamnya jenis serta ukuran bisnis.

Sistem informasi akutansi biaya harus dapat mencerminkan pembagian otoritas yang jelas sehingga manajer dapat dimintai pertanggung jawabannya. Sistem tersebut harus didesain untuk 
menyediakan informasi bagi manajemen agar dapat melakukan identifikasi dengan segera atas aktivitas-aktivitas yang memerlukan perhatian. Suatu sistem informasi dikatakan berhasil jika dapat disesuaikan dengan kebutuhan dan memadukan efisiensi antara kesederhanaan dan kecanggihan.

Meskipun demikian hasil dari catatan akuntansi tidak dapat memberikan seluruh informasi yang diperlukan untuk manajemen dalam melaksanakan operasional perusahaan yang efektif. Manajemen harus mendapatkan informasi sesuai dengan kebutuhan untuk mengetahui kegunaan dan keterbatasan informasi yang diterima. Menyesuaikan dengan persyaratan pelaporan yang ditentukan oleh pihak eksternal terdiri dari persyaratan hukum, undang-undang dan kontraktual yang harus dipenuhi oleh sistem yang efektif dalam biaya. Sedangkan kecanggihan sistem ditentukan oleh manajemen berdasarkan nilai yang dihasilkan.

\section{Klasifikasi Biaya}

Klasifikasi biaya sangat penting untuk dilakukan dengan membuat ikhtisar atas data biaya, dan klasifikasi yang paling umum digunakan dan didasarkan pada hubungan antar biaya, seperti berikut ini:
a. Produk
b. Volume produksi
c. Departemen, proses, pusat biaya, ataupun subdivisi dari manufaktur
d. Periode akuntansi
e. Keputusan, tindakan maupun evaluasi. 


\section{Hubungan Biaya dengan Produk}

Pengklasifikasian biaya dan beban dimulai dengan menghubungkan biaya pada tiap tahapan yang berbeda dalam tahapan operasi suatu entitas bisnis. Di setiap proses manufaktur terdapat total biaya yang terdiri dari biaya manufaktur dan biaya komersial.

Biaya manufaktur yang sering juga disebut biaya pabrikasi, biaya pabrik, biaya produksi merupakan jumlah biaya dari tiga elemen yaitu biaya bahan baku langsung, biaya tenaga kerja langsung dan biaya overhead pabrik. Untuk elemen biaya bahan baku langsung dan tenaga kerja langsung merupakan biaya utama (prime cost). Sedangkan tenaga kerja langsung dan overhead pabrik merupakan biaya konversi (conversion cost)

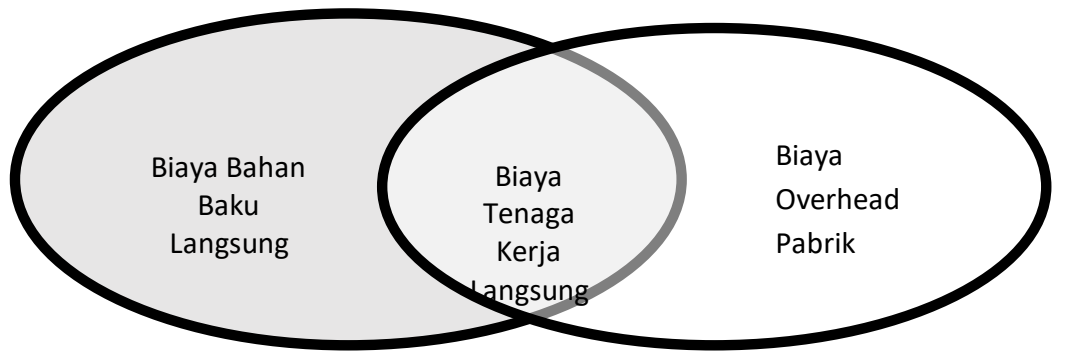

Biaya Utama

Biaya Konversi

Gambar 2.1 Pemisahan Biaya Utama dan Biaya Konversi

Biaya bahan baku langsung adalah semua biaya bahan baku dari produk jadi dan dimasukkan dalam perhitungan biaya produk. Contoh dari bahan baku langsung adalah kain untuk produksi 
pakaian jadi, sedangkan kancing maupun aksesoris lain yang jumlahnya tidak selalu sama dalam setiap produk maka kancing maupun aksesoris lain merupakan bahan baku tidak langsung.

Tenaga kerja langsung yang diperhitungkan dalam akuntansi biaya adalah tenaga kerja yang melakukan proses dan berkenaan langsung dengan produk dengan melakukan konversi bahan baku langsung hingga menjadi produk jadi. Identifikasi tenaga kerja langsung dan tak langsung akan sulit dilakukan untuk perusahaan yang telah melakukan otomatisasi, dimana ada tenaga kerja yang tidak hanya mengerjakan pekerjaan langsung tapi juga pekerjaan tak langsung. Ataupun beberapa tenaga kerja dapat bertukar peran secara bergantian sehingga ada elemen biaya yang sulit dipisahkan.

Dalam biaya konversi hanyalah biaya bahan baku langsung yang benar-benar bisa ditelusuri secara langsung kedalam produk.

Overhead Pabrik yang dapat disebut juga sebagai biaya manufaktur, biaya pabrikasi, beban manufaktur terdiri dari beban yang tidak dapat ditelusuri secara langsung ke dalam produk. Biaya overhead pabrik terdiri dari biaya selain biaya bahan baku langsung dan biaya tenaga kerja langsung.

Beban Komersial adalah biaya yang dikeluarkan oleh perusahaan dalam operasional yang terdiri dari beban administrasi yaitu seluruh biaya yang dikeluarkan untuk melaksanakan seluruh operasional perusahaan. Dan beban pemasaran yang merupakan biaya yang dikeluarkan oleh perusahaan untuk melakukan pemasaran atas produk yang dihasilkan yang mencakup beban promosi, penjualan dan pengiriman. Beban komersial ini akan dimasukkan dalam laporan laba rugi. 
Untuk biaya yang berhubungan dengan volume produksi adalah biaya variabel, biaya tetap dan biaya semi variabel. Dalam melaksanakan proses produksi biaya variabel merupakan biaya yang akan berubah secara proporsional terhadap perubahan aktivitas, dimana semakin tinggi aktivitas maka akan semakin tinggi pula biaya variabel yang dihasilkan. Biaya tetap merupakan biaya yang bersifat konstan secara total dalam rentang yang relevan, dan semakin tinggi aktivitas maka biaya tetap besarannya akan sama dengan syarat tidak melebihi kapasitas maksimum. Dan biaya semivariabel dimana terdiri dari elemen biaya tetap dan biaya variabel yang dalam tiap produksi selalu terdiri dari dua elemen tersebut.

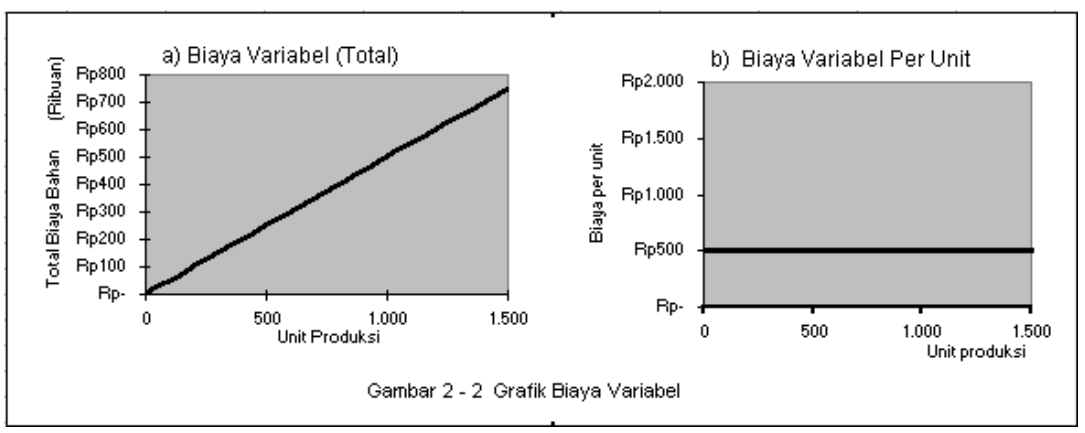

Gambar 2.2 Grafik Biaya Variabel 
a). Biaya Tetap (Total)

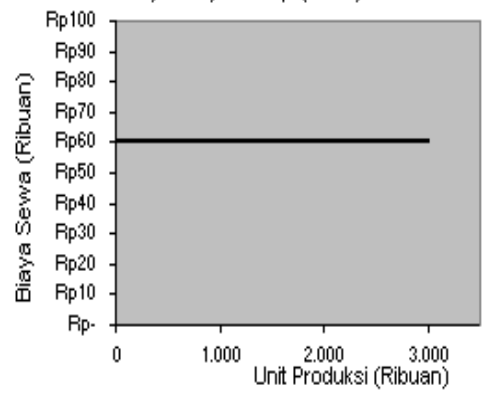

b). Biaya Tetap (Per Unit)

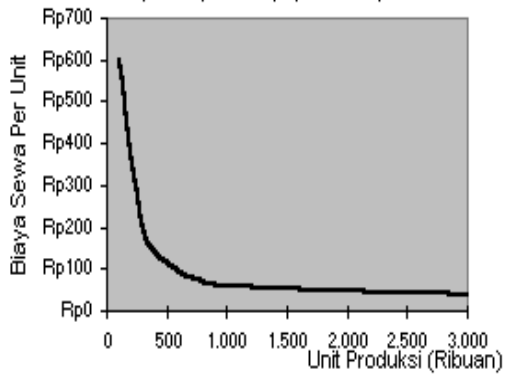

Gambar 2.3 Grafik Biaya Tetap

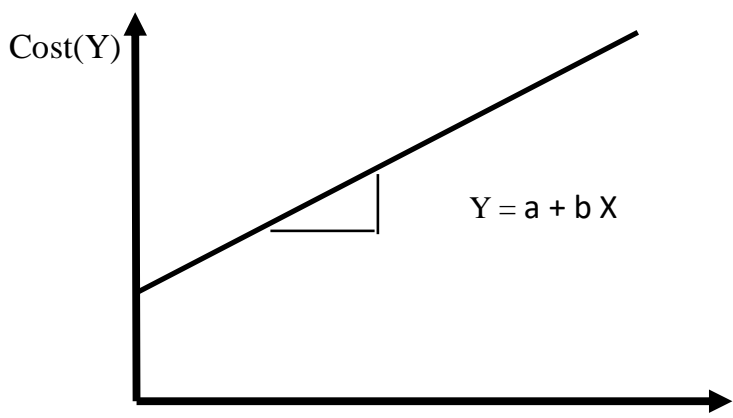

Activity (unit) X

Gambar 2.4 Biaya Semi Variabel

Tujuan pemisahan biaya tetap, biaya variabel dan biaya semi variabel.

a. Perhitungan tarif biaya overhead predeterminasi dan analisis varians.

b. Persiapan anggaran fleksibel dan analisis varians. 
c. Perhitungan biaya langsung dan analisis varians.

d. Analisis titik impas dan analisis biaya volume laba.

e. Analisis biaya diferensial dan komparatif.

f. Analisis memaksimalkan laba dan meminimalkan biaya jangka pendek.

g. Analisis anggaran modal.

h. Analisis Profitabilitas pemasaran berdasarkan daerah, produk dan pelanggan.

Biaya dalam hubungannya dengan keputusan, tindakan dan evaluasi. Dalam penentuan biaya untuk memilih alternatif dari beberapa pilhan harus diperhitung biaya yang berbeda jika suatu alternatif dipilih. Lebih sering disebut sebagai biaya relevan (biaya diferensial). Dengan biaya relevan ini manajemen memperhitungkan, memilih dan menentukan alternatif, tindakan maupun evaluasi untuk perbaikan.

Biaya dalam hubungannya dengan departemen produksi /segmen lain. Dengan terlaksanakannya produksi, maka munculnya departemen produk yang menyajikan seluruh biaya yang berkenaan dengan produksi. Departemen jasa merupakan departemen yang mempunyai fungsi membantu departemen produksi, sehingga muncul biaya departemen jasa yang akan dialokasikan ke dalam departemen produksi untuk selanjutnya diperhitungkan dalam laporan laba rugi.

Selain biaya produksi dan jasa juga terdapat biaya bersama (commen cost) yang merupakan biaya yang dianggarkan untuk produksi beberapa produk sejenis. Biaya gabungan adalah biaya yang digunakan untuk memproduksi beberapa jenis produk dengan perlakuan yang sama. 
Biaya dalam hubungannya dengan Periode Akuntansi. Untuk mengklasifikasikan biaya dengan periode akuntansi, maka biaya diakui sebagai modal belanja (capital expenditure) yaitu belanja yang memberikan manfaat untuk masa-masa mendatang dan akan dilaporkan sebagai aset. Selain diakui sebagai modal belanja juga diakui sebagai belanja pendapatan, dimana belanja tersebut memberikan manfaat untuk periode sekarang dan merupakan beban. Sedangkan aset akan menjadi beban dan hilang ketika dikonsumsi atau bahkan telah hilang manfaat ataupun kegunaannya.

Hubungan Biaya dalam Pengambilan Keputusan, Tindakan, atau Evaluasi. Untuk menentukan pilihan diantara beberapa alternatifalternatif ataupun tindakan-tindakan yang memungkinkan untuk dilakukan, kita harus dapat melakukan identifikasi atas biaya yang ada (merupakan penambahan atau pengurangan pendapatan, biaya maupun adanya penghematan) dan relevan terhadap pilihan-pilihan tersebut. Untuk lebih diperhatikan manajemen bahwa acapkali faktor-faktor yang tidak relevan disalahartikan sebagi faktor yang relevan sehingga akan mempengaruhi keputusan, tindakan maupun evaluasi yang dipilih bukan merupakan alternatif yang terbaik.

Selain disebut biaya relevan, nama lainnya adalah biaya diferensial dan sering pula disebut sebagai biaya marginal maupun biaya inkremental. Jika terjadi hilangnya pendapatan maupun manfaat lain sebagai akibat atas pengambilan suatu keputusan berdasarkan alternatif, maka hal itu disebut sebagai biaya oportunitas dari alternatif yang telah diambil. Dan apabila ada biaya yang telah terjadi akan tetapi tidak relevan terhadap alternatif 
pengambilan keputusan adalah merupakan biaya tenggelam (sunk cost). Dalam keputusan untuk meghilangkan ataupun menggantikan produk maupun departemen dan terdapat biaya yang tidak terpengaruh dengan adanya keputusan tersebut disebut sebagai biaya yang tak dapat dihindarkan. Di lain pihak jika terdapat biaya yang dapat dihindarkan dalam pengambilan keputusan, maka itu disebut sebagai biaya relevan.

\section{Soal Diskusi}

1. Jelaskan bagaimana keterkaitan, persamaan dan karakteristik yang membedakan biaya dan beban.

2. Jelaskan yang dimaksud dengan bahan baku tidak langsung dengan memberikan contohnya.

3. Jelaskan yang dimaksud dengan tenaga kerja tak langsung, dan berikan contohnya.

4. Apakah yang dimaksud dengan departemen jasa? Dan berikan contohnya.

5. Apakah yang dimaksud dengan departemen produksi, bagaimana klasifikasi pembebanan yang diterima dari departemen jasa.

6. Belanja dibagi dalam dua kategori yaitu belanja modal dan belanja umum. Bedakan kedua kategori dan bagaimana perlakuannys ke dalam akun.

7. Bagaimana dampak terhadap neraca dan laporan laba rugi yang telah diketahui saat ini ataupun masa yang akan datang sebagai suatu akibat dari pengklasifikaan yang tidak sesuai.

\section{Soal Perhitungan dan Analisis}


1. PT Manggala produsen sofa bed berbahan busa, untuk setiap unit sofa bed yang diproduksi membutuhkan bahan baku langsung Rp. 500.000,00; biaya tenaga kerja langsung Rp. 200.000,00 dan overhead pabrik Rp. 100.000,00. Sedangkan biaya overhead tetap Rp. 300.000,00.

Diminta:

a. Identifikasikan total biaya manufaktur per unit.

b. Identifikasikan biaya utama tiap unit.

c. Identifikasikan biaya konversi tiap unit.

d. Berapa total biaya manufaktur dalam 1 bulan jika berproduksi sebanyak 100 unit.

2. SunTea Company pada tahun 2015 memiliki penjualan sebesar Rp. 748.000.000,00 dengan rincian biaya variabel sebesar Rp. 375.000.000,00 dan biaya tetap sebesar Rp. 282.000.000,00. Perkiraan untuk tahun 2016 akan terjadi penurunan penjualan sebesar $10 \%$. Hitung perkiraan laba di tahun 2016, dengan biaya tetap tidak akan berubah. 


\section{BAB 3}

\section{PERILAKU BIAYA}

Perubahan biaya sangat bervariasi dalam tiap periode produksinya hal ini tentu saja sangat berkaitan dengan perubahan aktivitasnya. Dan perubahan aktivitas ini menjadi tantangan bagi manajemen karena perusahaan membutuhkan perubahan sesuai dengan kebutuhan. Manajemen memerlukan seluruh informasi agar dapat melakukan perencanaan terhadap aktivitas yang akan dilaksanakan, memperhitungkan biaya yang efektif dan efisien.

\section{Klasifikasi Biaya}

Seperti yang telah dijelaskan dalam Bab sebelumnya bahwa keberhasilan dalam perencanaan dan pengendalian bergantung kepada pengidentifikasian aktivitas dan biaya. Diperlukan identifikasi terhadap biaya yaitu biaya tetap, biaya variabel dan semi variabel.

Biaya tetap didefinisikan sebagai biaya yang secara total tidak akan berubah walaupun aktivitas berubah. Akan tetapi sebenarnya biaya tetap bisa menjadi biaya variabel untuk jangka panjang karena ada beberapa biaya yang akan berubah. Jika diestimasikan bahwa semua aktivitas bisnis akan mengalami penurunan bahkan hingga ke titik nol dan tidak ada prospek terjadi kenaikan, maka perusahaan akan melikuidasi diri dan menghindari semua biaya yang muncul.

Akan tetapi jika diperkirakan aktivitas mengalami kenaikan, biaya tetap akan dinaikan untuk menangani jika terjadi kenaikan volume aktivitas. Sebagai contoh, dalam overhead pabrik dimasukkan item sewa, asuransi, penyusutan, pajak properti dan lain 
sebagainya. Jika diperkirakan terjadi kenaikan aktivitas maka manajemen akan mengusahakan penambahan aset untuk produksi. Penambahan ini dipergunakan untuk menaikkan tingkat pengeluaran atas seluruh item dalam overhead pabrik.

Biaya variabel merupakan biaya yang nilai totalnya akan meningkat dan menurun secara proporsional sesuai dengan peningkatan ataupun penurunan tingkat aktivitas. Yang termasuk biaya variabel antara lain biaya bahan baku langsung, biaya tenaga kerja langsung, biaya bahan penolong, biaya tenaga kerja tak langsung, perlengkapan, dan lain sebagainya. Biaya variabel mudah diidentifikasi karena berhubungan secara langsung dengan perubahan tingkat aktivitas.

Hubungan antara biaya variabel dan tingkat aktivitas seringkali dianggap linier. Akan tetapi secara aktual hubungan aktivitas dengan biaya variabel tidak linier sempurna, hal ini karena adanya perubahan tingkat efisiensi baik meningkat maupun menurun. Bila terjadi perubahan kondisi atau bahkan tingkat aktivitas yang berada diluar rentang yang relevan, maka perlu diperhitungkan biaya variabel yang baru sesuai aktivitas yang ada.

Biaya semivariabel adalah biaya yang menunjukkan karakteristikkarakteristik biaya baik tetap maupun variabel. Sebagai contoh biaya perlengkapan, biaya pemeliharaan, biaya air, biaya listrik, biaya bahan bakar, biaya asuransi, biaya sewa, pajak penghasilan, biaya representasi, biaya perjalanan, dan lain sebagainya.

Terdapat dua alasan munculnya karakteristik semivariabel disebabkan oleh pengeluaran, yaitu: 
1. Adanya pengaturan minimum yang diperlukan atau tingkat kuantitas yang minimu dari perlegkapa maupun jasa dalam persiapan beroperasi.

2. Adanya klasifikasi akuntansi, yang berdasarkan objek pengeluaran maupun fungsi pengeluaran muncul biaya tetap dan biaya variable secara bersamaan.

Pada praktiknya manajemen dalam menentukan pengklasifikasian biaya tetap dan biaya variabel berdasakan pengalaman pribadi dari tiap manajemen. Sehingga lebh sering dengan perilaku pengamatan seperti itu hasil estimasi biaya menjadi tidak dapat diandalkan. Dalam pengamatan biasa terhadap jenis biaya, maka perilaku biaya yang dihasilkan tidak selalu terlihat.

Kemudian, seringkali pihak manajemen berusaha menyederhanakan proses produksi tersebut dengan mengklasifikan setiap biaya seluruhnya sebagai biaya tetap ataupun sebagai biaya variabel dan mengabaikan bahwa terdapat biaya semi variabel didalamnya. Oleh karena itu untuk mengklasifikasikan dan mengestismasikan biaya tetap, biaya variabel dan biaya semivariabel terdapat 2 metode perhitungan yaitu (1) Metode perhitungan tinggi rendah, (2) Metode perhitungan kuadrat terkecil. Metode perhitungan ini tidak hanya untuk mengestimasikan elemen biaya tetap dan biaya variabel akan tetapi dipergunakan untuk menentukan apakah seluruh biaya tetap ataukah seluruh total biaya variabel dalam rentang waktu aktivitas yang relevan.

Perlu diingat penggunaan metode perhitungan yang menghasilkan analisis perilaku biaya akan lebih tepat dibandingkan dengan penilaian manajemen. Analisa yang dihasilkan juga bergantung atas data historis. Jika dalam suatu periode terjadi suatu 
kondisi yang abnormal, maka lebih baik segera elemen yang abnormal untuk dikeluaran dari sampel. Untuk mengilustrasikan kedua metode perhitungan dalam penentuan elemen biaya tetap dan variabel, dipergunakan data dari Manggala Company pada Tabel 3-1 sesuai data historis tahun lalu.

\section{Manggala Company}

\section{Biaya Pemeliharaan dan Data Jam Mesin}

\begin{tabular}{llll}
\hline \multicolumn{1}{c}{ Bulan } & \multicolumn{2}{c}{ Biaya Pemeliharaan } & Jam Mesin \\
\hline Januari & $\mathrm{Rp}$ & $1.500 .000,00$ & 620 \\
Februari & $\mathrm{Rp}$ & $1.450 .000,00$ & 540 \\
Maret & $\mathrm{Rp}$ & $1.440 .000,00$ & 520 \\
April & $\mathrm{Rp}$ & $1.650 .000,00$ & 700 \\
Mei & $\mathrm{Rp}$ & $1.480 .000,00$ & 540 \\
Juni & $\mathrm{Rp}$ & $1.300 .000,00$ & 500 \\
Juli & $\mathrm{Rp}$ & $1.550 .000,00$ & 640 \\
Agustus & $\mathrm{Rp}$ & $1.370 .000,00$ & 510 \\
September & $\mathrm{Rp}$ & $1.460 .000,00$ & 520 \\
Oktober & $\mathrm{Rp}$ & $1.410 .000,00$ & 640 \\
November & $\mathrm{Rp}$ & $1.520 .000,00$ & 510 \\
\hline \hline
\end{tabular}

Tabel 3-1 


\section{Metode Tinggi Rendah (High and Low Points)}

Dalam menggunakan metode tinggi-rendah untuk mengetahui besaran elemen biaya tetap dan elemen biaya variabel dari suatu biaya menggunakan dua titik. Titik dari data yang dipilih berdasarkan periode yang disajikan secara historis merupakan tingkat aktivitas dengan nilai aktivitas tertinggi dan terendah. Dalam periode yang disajikan memiliki jumlah tertinggi dan terendah untuk biaya yang dianalisis, walaupun tidak selalu tersaji dalam setiap periode. Apabila terdapat titik aktivitas dengan jumlah biaya tertinggi dan terendah tidak berada dalam periode yang sama maka nilai yang dipilih adalah aktivitasnya yang merupakan pemicu biaya. Diplih jumlah biaya yang paling tinmggi dan paling rendfah karena dianggap dapat mewakili kondisi dari tingkat aktivitas yang berbeda dengan rentang yang berjauhan. Akan tetapi perlu diperhatikan jika aktivitas dan biaya tersebut dalam periode dengan kondisi yang abnormal yang mengakibatkan data tidak sesuai.

Berdasarkan data yang historis dari Manggala Company, maka penetuan elemen tetap dan elemen variabel, adalah sebagai berikut :

\section{Tingkat}
Biaya
Aktivitas

Tinggi

Rp $1.650 .000,00$

700

Rendah

Rp $\quad 1.300 .000,00$

500

Selisih

Rp $350.000,00$

200 
Tarif biaya variabel: $\mathrm{Rp} 350.000,00 / 200=\mathrm{Rp} 1.750,00$ per jam mesin

Tinggi
Rp $1.650 .000,00$
$\operatorname{Rp} 1.300 .000,00$

Total Biaya

Biaya Variabel

Rp $1.225 .000,00$

$\mathrm{Rp}$

$875.000,00$

Rendah

Biaya Tetap

Rp $425.000,00$

$\mathrm{Rp}$

$425.000,00$

\# Jam mesin $\times$ Rp 1.750,00

Pada data tingkat aktivitas dengan nilai tinggi dan rendah berbeda 200 jam mesin, dan selisih biaya Rp 1.750,00. Terjadi perbedaan aktivitas dan biaya tersebut diasumsikan murni karena adanya perbedaan tingkat aktivitas yang diukur sehingga merupakan selisih variabel. Untuk menghitung tarif variabel adalah dengan membandingkan selisih aktivitas dan biaya. Selisih biaya sebesar Rp 1.750,00 dan selisih aktivitas adalah 200 jam mesin. Diperoleh tarif variabel $\mathrm{Rp} 1.750,00$ per jam mesin.

Total biaya variabel untuk tingkat aktivitas dan tingkat aktivitas tinggi diperoleh dengan mengalikan tarif variabel dengan tingkat aktivitas. Dihasilkan nilai total biaya variabel aktivitas rendah Rp 875.000,00 (Rp 1.750,00 × 500 jam mesin) dan nilai total biaya variabel aktivitas tinggi $R p$ 1.225.000,00 (Rp 1.750,00 x 700 jam mesin). Dari selisih total biaya dengan biaya variabel baik di tingkat aktivitas rendah maupun tingkat aktivitas tinggi diperoleh selisih dengan jumlah yang sama yaitu $\mathrm{Rp} 425.000,00$ yang merupakan biaya tetap. Setelah memperhitungkan biaya tetap dan biaya 
variabel maka telah ndapat diestimasikan total biaya untuk berbagai tingkat aktivitas yang ada.

Metode tinggi rendah merupakan metode yang paling sederhana, namun memiliki keterbatasa dikarenakan hanya mempergunakan dua titik dalam penentuan perilaku biaya. Selain itu mengasumsikan bahwa titik-titik lain berada dalam garis lurus diantara titik tertinggi dan terendah, sehingga hasil akan bias. Oleh karenanya perhitungan perilaku biaya dengan menggunakan metode tinggi rendah menghasilkan informasi yang kurang akurat, jika dibandingkan dengan metode lain.

\section{Metode Kuadrat Terkecil}

Metode kuadrat terkecil yang seringpula disebut sebagai analisis regresi, adalah metode dengan penentuan berdasarkan data yang ada secara matematis garis yang paling sesuai dengan titik sebenarnya. Untuk dapat menampilkan perhitungan seperti di dalam Tabel 3-2, perlu dipersiapkan sesuai langkah-langkah berikut ini:

1. Tentukan rata-rata biaya pemeliharaan $(\bar{y})$, dan rata-rata jam mesin ( $\dot{x})$. Jumlahkan seluruh biaya pemeliharaan di kolom 1 kemudian bagi dengan jumlah observasi. Rata-rata biaya pemeliharaan $(\bar{y})$ adalah Rp 1.455,00 (Rp 17.460,00 $\div 12$ bulan). Jumlahkan seluruh tingkat aktivitas yaitu jam mesin bagi dengan jumlah observasi. Sehingg rata-rata jam mesin (x) adalah 563,3 (6760 $\div 12$ bulan).

2. Setelah mendapatkan rata-rata biaya pemeliharaan dan rata-rata jam mesin di kolom 1 dan kolom 3. Kemudian hitunglah selisih antara biaya rata-rata dibandingkan dengan biaya pemeliharaan aktual bulanannya masukkan di kolom 2, dan hitung selisih jam mesin dengan membandingkan jam 
mesin rata-rata dengan jam aktual tiap bulannya masukkan di kolom 4.

3. Selanjutnya mengkuadratkan setiap angka di kolom $4\left(x_{i}-\dot{x}\right)$ hasilnya masukkan ke kolom $5\left(x_{i}-\dot{x}\right)^{2}$ dan jumlahkan kolom 5. Kalikan setiap angka di kolom $4\left(x_{i}-\dot{x}\right)$ dengan setiap angka di kolom $2\left(\mathrm{y}_{\mathrm{i}}-\overline{\mathrm{y}}\right)$ yang sesuai masukkan ke kolom $6\left(\mathrm{x}_{\mathrm{i}}-\dot{\mathrm{x}}\right)\left(\mathrm{y}_{\mathrm{i}}-\overline{\mathrm{y}}\right)$ kemudian jumlahkan. Dan terakhir kuadratkan tiap angka yang ada dikolom $2\left(y_{i}-\bar{y}\right)$ masukkan ke kolom $7\left(y_{i}-\bar{y}\right)^{2}$ dan jumlahkan.

\begin{tabular}{|c|c|c|c|c|c|c|c|}
\hline & 1 & 2 & 3 & 4 & 5 & 6 & 7 \\
\hline \multirow[b]{2}{*}{ Bulan } & $y_{i}$ & $\left(y_{i}-\bar{y}\right)$ & $x i$ & $\left(x_{i}-\dot{x}\right)$ & $\left(x_{i}-\dot{x}\right)^{2}$ & $\begin{array}{c}\left(x_{i}-\dot{x}\right)\left(y_{i^{-}}\right. \\
\bar{y})\end{array}$ & $\left(y_{i}-\bar{y}\right)^{2}$ \\
\hline & $\begin{array}{c}\text { Biaya } \\
\text { Pemelih } \\
\text { araan }\end{array}$ & $\begin{array}{c}\text { Selisih } \\
\text { dari } \\
\text { rata2 } \\
\text { biaya } \\
\text { Rp } \\
1.422,0 \\
0\end{array}$ & $\begin{array}{c}\text { Jam } \\
\text { Mesin }\end{array}$ & $\begin{array}{c}\text { Selisih } \\
\text { dari } \\
\text { rata2 } \\
\text { biaya } \\
\text { Rp } \\
1.422,0 \\
0\end{array}$ & $\begin{array}{c}4 \\
\text { dikuad } \\
\text { ratkan }\end{array}$ & $4 \times 2$ & $\begin{array}{c}2 \\
\text { dikuad } \\
\text { ratkan }\end{array}$ \\
\hline Januari & 1500 & 45 & 620 & 56,7 & 3211 & 2550 & 2025 \\
\hline Februari & 1450 & -5 & 540 & $-23,3$ & 544,4 & 116,667 & 25 \\
\hline Maret & 1440 & -15 & 520 & $-43,3$ & 1878 & 650 & 225 \\
\hline April & 1650 & 195 & 700 & 136,7 & 18678 & 26650 & 38025 \\
\hline & & & & & & - & \\
\hline Mei & 1480 & 25 & 540 & $-23,3$ & 544,4 & 583,333 & 625 \\
\hline Juni & 1300 & -155 & 500 & $-63,3$ & 4011 & 9816,67 & 24025 \\
\hline Juli & 1550 & 95 & 640 & 76,7 & 5878 & 7283,33 & 9025 \\
\hline
\end{tabular}




\begin{tabular}{lccccccr} 
Agustus & 1370 & -85 & 510 & $-53,3$ & 2844 & 4533,33 & 7225 \\
September & 1460 & 5 & 520 & $-43,3$ & 1878 & 216,667 & 25 \\
Oktober & 1520 & 65 & 640 & 76,7 & 5878 & 4983,33 & 4225 \\
November & 1330 & -125 & 510 & $-53,3$ & 2844 & 6666,67 & 15625 \\
Desember & 1410 & -45 & 520 & $-43,3$ & 1878 & 1950 & 2025 \\
& 17460 & 0 & 6760 & 0 & 50067 & 64400 & 103100 \\
\hline
\end{tabular}

Seluruh perhitungan yang ada dalam tabel 3-2 dipakai untuk memperhitungkan elemen biaya tetap dan variabel. Untuk memperhitungkan tarif biaya pemeliharaan $(b)$ dengan perhitungan sebagai berikut:

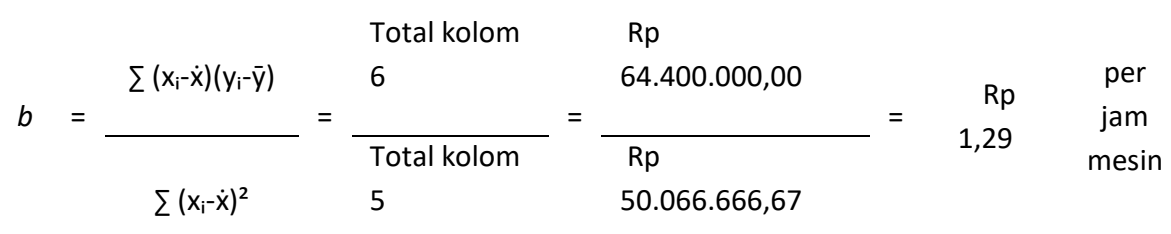

Untuk menghitung biaya tetap yaitu a, menggunakan rumus untuk garis lurus, sebagai berikut :

$$
\begin{aligned}
& \bar{y}=a+b \dot{x} \\
& \operatorname{Rp} 1.335,00=a+(\operatorname{Rp~1,29)}(520) \\
& \operatorname{Rp} 1.335,00=a+\operatorname{Rp} 668,87
\end{aligned}
$$

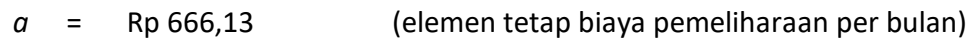


* dalam

ribuan

Dari perhitungan dengan memakai metode yang matematis, ketepatan hasil dari metode kuadrat terkecil akan memberikan tingkat objektivitas yang tinggi dalam analisis untuk pengambilan keputusan. Untuk menggunakan metode kuadrat terkecil haruslah memiliki jumlah data yang cukup besar yang dapat mewakili kondisi normal operasional.

\section{Metode Kuadrat Terkecil untuk Beberapa Variabel Independen}

Dalam perilaku biaya, biaya itu sendiri merupakan variabel dependen dalam pengukuran volume ataupun variabel independen lainnya. Seperti dalam pembahasan Manggala Company perilaku biaya variabel dependen adalah biaya pemeliharaan, dan variabel independen adalah jam mesin. Akan tetapi biaya akan lebih bervariasi karena terdapat lebih dari satu faktor yang mempengaruhi.

Analisis regresi berganda yang merupakan penerapan danperluasan lebih lanjut dari metode kuadrat terkecil, yang memberikan hasil analisis semakin luas untuk memasukkan lebih dari satu variabel independen. Meskipun hubungan biaya tidak dapat lagi diperlihatkan dalam grafik dua dimensi dan perhitungan secara aritmatika menjadi lebih rumit, ketersediaan program komputer secara luas membuat analisis regresi berganda menjadi mungkin dilakukan.

Konsep kuadrat terkecil ketika terdapat dua atau lebioh variabel independen pada dasarnya sama dengan ketika hanya terdapat satu variabel. Asumsi normalitas masih tetap berlaku. 
Namun, dengan adanya regresi berganda muncul kasus dimana distribusi probabilitas gabungan variabel yang diasumsikan terdistribusi secara normal (kadang-kadang disebut sebagai multivariasi normal). Satu asumsi tambahan adalah bahwa variabel independen tidak berkorelasi antara satu dengan yang lainnya, maka variabel-variabel tersebut bersifat kolinear atau kondisi yang disebut multikolinearitas. Ketika tingkat multikolireanitas tinggi, maka hubungan antara satu atau lebih variabel independen dengan variabel independen lainnya menjadi kabur. Adanya multikolinearitas tidak akan mempengaruhi estimasi biaya kecuali bila satu atau lebih variabel independen penting sehingga ukuran aktivitas diabaikan dari model regresi karena kurang memiliki hubungan dengan variabel dependen (biaya). Mengabaikan variabel penting dalam model regresi berganda disebut sebagai kesalahan spesisfikasi dan lebih mengarah kepada masalah dalam menganalisis sumber terjadinya biaya dan bukannya kesalahan dalam mengestimasi biaya.

Jika perilaku biaya dari sekelompok pengeluaran dalam satu atau lebih akun buku besar dideskripsikan, alternatif untuk variabel berganda (dan pertimbangan yang ditimbulkan oleh variabel berganda ketika menggunakan metode kuadrat terkecil) akan menjadi memungkinkan. Yaitu, beban bisa dikelompokkan dan diklasifikasikan dengan rinci sedemikian rupa sehingga beban dari satu kelompok tertentu sebagian besar berhubungan dengan hanya satu variabel independen. Hal ini akan memungkinkan penggunaan metode kuadrat terkecil seperti yang telah diilustrasikan sebelumnya, yaitu analisis regresi sederhana. Jika pendekatan inii tidak mungkin dilakukan ketika lebih dari satu variabel independen masih diperlukan untuk mendeskripsikan perilaku biaya, maka regresi berganda sebaiknya digunakan. 
Oleh karena itu bisnis memiliki sifat yang sangata dinamis, perusahaan sering dihadapkan kepada kebutuhan untuk membuat perubahan-perubahan dalam tingkatan aktivitas serta bauran aktivitas didalam bisnisnya. Bagi pihak manajemen dalam merencanakan aktivitas suatu perusahaan dengan cerdik dan cermat, kemudian mengendalikan biayanya secara efektif, hubungan antara terjadinya biaya dengan perubahan dalam aktivitas harus dapat dipahami secara menyeluruh. Dalam bab ini yang membahas dampak dari perubahan-perubahan dalama aktivitas bisnis terhadap biaya dan pengklasifikasian biaya sebagai biaya tetap, biaya variabel, dan biaya semivariabel dalam hubungannya dengamn aktivitas. Dalam penjelasan diatas menjelaskan dua metode yaitumetode tinggi rendah dan metode kuadrat terkecil, dari informasi yang dihasil, maka metode kuadrat terkecil akan lebih akurat hasil analisisnya. Akan tetapi dalam metode kuadrat terkecil juga sangat bergantung kepada tingkat kolinearitas datanya. Koefisien korelasi sebaiknya digunakan untuk menemukan penentu yang paling akurat. Selain itu kesalahan standar dari estimasi dapat dihitung berdasarkan estimasi kuadrat terkecil dan digunakan untuk mengembangkan interval keyakinan untuk pengendalian biaya. Meskipun pembahasan berpusat pada biaya dan aktivitas produksi.

\section{Soal Diskusi}

1. Jelaskan apa yang menjadi perbedaan antara biaya tetap, biaya variabel dan biaya semivariabel

2. Bagaimana keuntungan dan kerugian apabila menggunakan penilaian manajerial dalam memisahkan biaya tetap dan biaya variabel?

3. Apa keuntungan masingmasing dari dua metode yang berbeda dalam memisahkan komponen tetap dan komponen variabel? 
4. Apa yang dimaksud dengan kesalahan standar dari estimasi.

\section{Soal Latihan}

1. Metode Tinggi Rendah

Pradhana Company ingin memisahkan elemen biaya tetap dan variabel dari biaya listriknya, dimana perusahaan meyakini bahwa biaya yang muncul adalah biaya semivariabel. Data yang disajikan berikut ini adalah data 6 bulan:

\begin{tabular}{lccc}
\multicolumn{1}{c}{ Bulan } & Biaya Perakitan *) & $\begin{array}{c}\text { Jam Tenaga } \\
\text { Kerja Langsung }\end{array}$ \\
& & & \\
\hline Januari & $\mathrm{Rp}$ & 550,00 & 480 \\
Februari & $\mathrm{Rp}$ & 700,00 & 540 \\
Maret & $\mathrm{Rp}$ & 800,00 & 580 \\
April & $\mathrm{Rp}$ & 450,00 & 420 \\
Mei & $\mathrm{Rp}$ & 750,00 & 560 \\
Juni & $\mathrm{Rp}$ & 600,00 & 500 \\
& & & \\
*Dalam ribuan & & &
\end{tabular}

Tentukan biaya tetap dan biaya variabel dengan perhitungan tinggi rendah.

2. Metode Kuadrat Terkecil

Andalas Company berusaha memprediksikan beban perjalanan dinas dan representasi berdasarkan jumlah kunjungan penjualan kepada pelanggan. Selama 50 minggu 
terakhir, Divisi Pemasaran dalam perusahaan tersebut melaporkan bahwa tenaga pemasarannya melakukan kunjungan kepada pelanggan sebanyak 5.500 kunjungan atau rata-rata 110 kunjungan dalam tiap minggunya. Beban perjalanan dinas dan presentasi untuk peride yang sama totalnya sebesar $\mathrm{Rp} 7.500 .000,00$, atau rata-rata $\mathrm{Rp}$ 150.000,00 tiap minggu. Deviasi beban perjalanan dinas dan representasi dari rata-rata dikalikan dengan deviasi kunjungan pemasaran dari rata-rata dan ditotalkan $\left[\Sigma\left(\mathrm{x}_{\mathbf{i}}{ }^{-}\right.\right.$ $\dot{\mathrm{x}})\left(\mathrm{y}_{\mathrm{i}}-\overline{\mathrm{y}}\right)$ ] adalah sebesar 150.000 , dan deviasi kunjungan penjualan rata-rata kemudian dikuadratkan dan ditotalkan $\left[\Sigma\left(\mathrm{x}_{\mathrm{i}}-\dot{\mathrm{x}}\right)^{2}\right]$ adalah sebesar 5.000 


\section{BAB 4}

\section{SISTEM PERHITUNGAN AKUMULASI BIAYA}

Akuntansi biaya memiliki fungsi akuntansi biaya yang menbcakup pencatatan dan pengukuran elemen biaya pada saat sumber daya yang terkait dalam proses produksi. Semua biaya manufaktur, tanpa mempedulikan apakah bersifat tetap atau variabel, dimulai dengan akun barang dalam proses dan persediaan barang jadi. Baik dengan metode asumsi penyerapan penuh (full abdorption cost).

Dalam tiap proses produksi diperlukan pengaturan fisik dari pabrik, kemudian kebutuhan pengambilan keputusan oleh manajer untuk menentukan bagaimana biaya akan diakumulaikan. Dalam akun buku besar biasanya biaya manufaktur yang dimasukkan adalah Bahan Baku, Beban Gaji, Pengendali Overhead, Barang Dalam Proses, Barang Jadi, dan Harga Pokok Penjualan. Akun-akun dalam buku besar ini dipergunakan untuk mengakui dan mengukur aliran biaya, dimuali dari perolehan bahan baku, proses produksi, hingga harga pokok penjualan.

Untuk bagian biaya non manufaktur seperti beban penyusutan dan gaji bagian pemasaran dan administratif, akan mengurangi besaran hasil penjualan dalam laporan laba rugi. Dengan memperhitungkan seluruh biaya yang dikeluarkan baik variabel maupun tetap, maka hal ini mencerminkan metode perhitungan penyerapan penuh. 
Terdapat beberapa transaksi yang ditunjukkan dalam alur proses produksi dari perolehan barang hingga produk jadi, antara lain:

a. Pembelian Bahan Baku

b. Pengakuan biaya tenaga kerja produksi

c. Pengakuan biaya overhead pabrik

d. Penggunaan bahan baku

e. Distribusi beban gaji tenaga kerja

f. Pembebanan estimasi biaya overhead

g. Penyelesaian

h. Penjualan Produk

\section{Laporan Hasil Operasi}

\section{Laporan Laba Rugi}

Laporan laba rugi, dan harga pokok penjualan ditampilkan dalam satu angka. Akan tetapi untuk laporan yang akan dipublikasikan, serta tambahan informasi yang diperlukan untuk kebutuhan internal. Seperti pada tabel 4.1

MANGGALA COMPANY

LAPORAN LABA RUGI

UNTUK PERIODE YANG BERAKHIR 31 JANUARI

\begin{tabular}{|c|c|c|c|}
\hline Penjualan & & $\$$ & 255.000 \\
\hline Diskon penjualan & 13.000 & & \\
\hline Penjualan bersih & & $\$$ & 242.000 \\
\hline HPP & & $\$$ & 191.800 \\
\hline Laba kotor & & $\$$ & 50.200 \\
\hline \multicolumn{2}{|c|}{ Biaya administrasi dan pemasaran } & $\$$ & 35.000 \\
\hline \multicolumn{2}{|l|}{ Laba operasi } & $\$$ & 15.200 \\
\hline
\end{tabular}




\section{Tabel 4-1}

\section{Neraca}

Untuk melengkapi laporan laba rugi perlu ada Neraca yang menunjukkan posisi keuangan perusahaan, karena dengan menunjukkan salah satu laporan saja maka gambaran finansial tidak akan lengkap untuk melihat status dan kemajuan perusahaan. Seperti contoh dalam Tabel 4-2

\section{MANGGALA COMPANY}

NERACA

\section{PER 31 JANUARI}

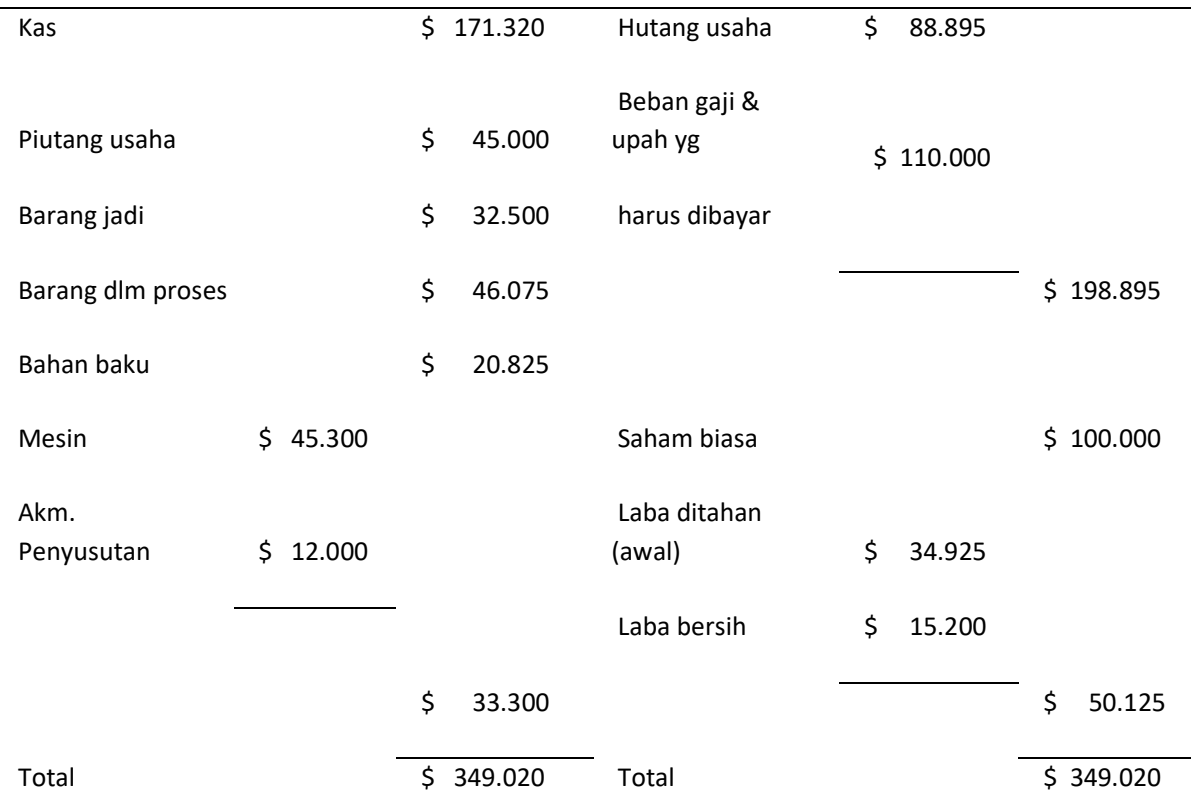

Tabel 4-2 


\section{Laporan Arus Kas}

Saat laporan laba rugi dan neraca disajikan untuk eksternal, maka dalam prinsip akuntansi kedua laporan tersebut yaitu neraca dan laba rugui harus dilengkapi dengan laporan arus kas. Untuk periode singkat yaitu satu bulan laporan arus kas sangat jarang dilakukan.

\section{Sistem Biaya}

Biaya yang dialokasikan dalam unit yang diproduksi dapat berupa biaya aktual atau biaya standar. Dalam sistem biaya aktual atau sistem biaya historis, informasi biaya akan diakumulasikan ketika biaya terjadi, akan tetapi penyajiannya akan ditunda hingg semua operasi dalam periode akuntansik tersebut selesai dilakukan. Sedangkan untuk sistem biaya standar, produk, operasi, dan proses dihitung biayanya berdasarkan jumlah yang telah ditentukan sebelumnya berdasarkan dari sumberdaya yang akan digunakan dan harga yang telkah ditentuklan berdasarkan dari informasi dalam periode sebelumnya. Biaya aktual akan diakumulasikan secara terpisah, varians atau selisih antara biaya aktual dan biaya standar dikumpulkan dalam akun yang terpisah. Seperti yang dijelaskan dalam Bab 2, biaya yang dialokasikan ke unit-unit yang diproduksi bisa mencakup seluruh biaya manufaktur (perhitungan penyerapan biaya penuh atau full absorption costing) atau hanya memperhitungkan biaya variabel (perhitungan biaya langsung atau direct costing atau variable costing).

Terdapat empat jenis sistem biaya yang dapat digunakan untuk mengkonstruksikan dengan mengakui biaya dapat diukur pada jumlah aktual atau jumlah standar, baik dalam perhitungan biaya langsung maupun biaya penyerapan penuh. Klasifikasi sistem biaya 
memiliki beberapa kemungkinan yang kesemuanya berdasarkan terminologi akuntansi biaya. Jika ada pertanyaan elemen apa saja yang dialokasikan ke dalam produksi, maka terdapat tiga kemungkinan, yaitu perhitungan biaya utama, perhitungan biaya variabel, dan perhitungan biaya penyerapan penuh. Akan tetapi jika pertanyaannya adalah bagaimana pengukuran elemen biaya, maka terdapat dua kemungkinan seperti yang telah dibahas sebelumnya yaitu semua biaya dapat diukur pada jumlah historis atau aktual, dan biaya yang diukur pada jumlah yang telah ditentukan sebelumnya atau biaya standar.

\section{Akumulasi Biaya}

Sistem biaya seperti yang telah dibahas sebelumnya dapat dipergunakan dalam perhitungan biaya berdasarkan pesanan (job order costing), dan perhitungan biaya berdasarkan proses (process costing), atau bahkan dengan metode akumulasi biaya lainnya.

Perhitungan biaya berdasarkan pesanan dan berdasarkan proses merupakan dua metode akumulasi biaya yang paling jamak dipergunakan, dan diantara keduanya memiliki beberapa kesamaan. Walaupun tujuan final kedua metode ini adalah biaya dari unit yang diproduksi, akan tetapi memiliki perbedaan mendasar terhadap metode penelusuran biaya. Untuk perhitungan berdasarkan pesanan biaya ditelusuri berdasarkan unit, lot, atau kontrak secara individual. Sehingga setiap kontrakl individual akan memiliki nilai dan penelusuran yang berbeda dengan kontrak lainnya. Sedangkan dalam perhotungan biaya berdasarkan proses, biaya akanditelusuri berdasarkan divisi, departemen, atau operasi dalam suatu produksi. 


\section{Sistem Perhitungan Biaya Berdasarkan Pesanan}

Untuk perhitungan biaya berdasarkan pesanan atau disebut juga job order costing, biaya akan diakumulasikan berdasarkan batch, lot, atau pesanan masing-masing pelanggan. Bahkan metode ini juga bisa dipakai oleh departemen atau pusat biaya yang menghasilkan produk dengan jenis yang heterogen. Dalam perhitungan biaya berdasarkan pesanan membutuhkan cara yang praktis agar dapat mengidentifikasi setiap pesanan yang dihasilkan dan membebankan beberapa elemen biaya ke dalam masing-masing pesanan. Harus memiliki catatan terperinci yang akan menunjukkan biaya dari setiap pesanan dalam akun buku pembantu untuk mendukung akun buku besar barang dalam proses.

Contoh penerapan perhitungan biaya berdasarkan pesanan adalah pekerjaan bengkel, reparasi, pesanan khusus di pabrik, pekerjaan konstruksi, percetakan, dan lain sebagainya.

Pada saat pesanan diproduksi dalam jumlah tertentu maka persediaan dan perhitungan biaya berdasarkan pesanan sangat memungkinkan perhitungan biaya tiap unit. Dan ketika pesanan dikerjakan sesuai dengan spesifikasi pelanggan, maka laba rugi untuk setiap pesanan akan lebih mudah diperhitungkan. Oleh karenanya perhitungan biaya berdasarkan pesanan memberikan peluang lebih bagi manajer untuk melakukan pengendalian biaya dan melakukan evaluasi terhadap profitabilitas terhadap suatu kontrak, produk, atau batch.

Perhitungan biaya berdasarkan pesanan mempunyai syarat yaitu berproduksi jika ada pesanan dan biaya akan diakumulasikan sesuai dengan pesanan yang membutuhkan. Dengan rumus: 


\section{BiayaProduksi}

Hargapokok / unit =

Unit yang dipesan

\section{Sistem Perhitungan Biaya Berdasarkan Proses}

Perhitungan biaya berdasarkan proses (Process Costing) adalah metode mengakumulasikan biaya berdasarkan proses produksi atau berdasarkan departemen.Departemen sendiri bisa menggunakan perhitungan biaya berdasarkan proses maupun perhotungan biaya berdasarkan pesanan. Yang harus dicermati disni adalah, departemen merupakan fokus dalam penelusuran biaya berdasarkan proses. Perhitungan biaya berdasarkan proses dipergunakan pada semua unit yang dikerjakan dalam suatu departemen yang bersifat homogen. Proses perhitungan biaya berdasarkan proses akan mengakumulasikan biaya tersebut dalam jumlah unit yang telah melewati proses dalam periode tertentu, yang hasilnya adalah biaya per unit. Apabila produk dari suatu proses akan menjadi bahan baku dalam proses berikutnya, maka biaya per unit akan diperhitungkan untuk masing-masing proses.

Contoh penggunaan perhitungan biaya berdasarkan proses adalah di pabrik kimia, pabrik minuman, dan lain sebagainya dimana perusahaan berproduksi dalam jumlah besar untuk satu jenis ataupun beberapa jenis produk.

Dalam sistem biaya aktual (historis) yang menggunakan perhitungan biaya berdasarkan proses, maka persediaan yang masih dalam proses akan menimbulkan masalah akuntansi, yaitu perlakuan biaya dari persediaan dalam proses tersebut ke dalam periode akuntansi berikutnya. Sedangkan pada praktiknya asumsi aliran biaya yang paling umum dipergunakan untuk memperhitungkan 
biaya berdasarkan proses adalah metode biaya rata-rata tertimbang(weighted average method), atau meratakan atau mencampur biaya dari persediaan awal yang belum selesai sepenhnya dengan biaya yang terjadi dalam periode ini.

Perhitungan biaya berdasarkan proses mempunyai syarat yaitu berproduksi sesuai dengan rencana yang telah ditentukan, dan biaya diakumulasikan sesuai dengan departemen bagian. Dengan rumus:

\section{BiayaProduksi}

Harga pokok / unit =

Unit Yang Diproduksi

\section{Metode Campuran}

Dalam beberapa perusahaan manufaktur, unit-unit yang berbeda memiliki biaya bahan baku langsung yang berbeda secara signifikas akan tetapi semua unit melalui proses yang sama dalam jumlah besar. Dalam hal ini biaya bahan baku langsung diakumulasikan menggunakan metode perhitungan biaya berdasarkan pesanan, sedangkan biaya konversi diakumulasikan dengan perhitungan biaya berdasarkan proses. Semakin banyak pabrik yang menggunakan metode perhitungan biaya campuran seperti kasus sistem manufaktur fleksibel (flexible manufacturing system-FMS). Semakin banyak pabrik yang beralih dari proses manufaktur yang melibatkan sistem manual maupun otomatisasi ke FMS. FMS merupakan sistem yanterdiri atas kumpulan proses produksi yang terotomatisasi, pergerakan bahan baku yang terotomatisasi dan sistem pengendalian terkomputerisasi yang seluruhnya terintegrasi untuk malukan proses produksi secara efisien atas variasi produk yang sangat fleksibel. Cakupan atas variasi 
produk sangat dibatasi oleh kebutuhan produkuntuk memiliki karakteristik-karakteristik umum tertentu yang memungkinkan pengelompokkan ke dalam suatu kelompok produk dimana pada saat yang bersamaan mempertahankan fleksibilitas yang cukup tinggi.

mempengaruhi banyak faktor yang harus dipertimbangkan oleh manajemen saat mengevaluasi sistem tertentu. Perbandingan dari faktor-faktor yang ada membuat FMS menjadi sistem yang menarik. Walaupun demikian, adopsi dari sistem FMS dan proses modernisasi lainnya akan terus berlanjt dan berkembang. Ap abila semua unit dari semua produk melalui FMS dengan tingkat kecepatan yang sama, maka semua unit akan dibebankan biaya konversi dalam jumlah yang sama, karena lama waktu konversi merupakan ukuran terbaik dari usaha konversi. Namun jika kecepatannya berbeda maka biaya konversi yang dibebankan kepada tiap unit sesuai dengan lamanya waktu proses.

Mengasumsikan fungsi mesin dalam FMS digunakan untuk menguji semua komponen elektronik setiap unit produk. Untuk produk yang paling sederhana yang dibuat oleh FMS hanya memiliki tiga komponen untuk diuji, sedangkan untuk produk dengan tingkat kerumitan tinggi mungkon akan memiliki 20 komponen elektronik untuk diuji. Apabila satu mesin penguji menghabiskan waktu selama tida detik untuk melakukan semua pengujian untuk masing-masing unit maka tanpa memperdulikan jumlah unit yang diuji tiap unit akan mendapatkan waktu yang sama serta memerlukan sumber daya yang sama. Akan tetapi bila jumlah dan biaya bahan baku serta suku cadang bervariasi secara signifikasn dari satu produk ke produk.

Sehingga suatu buku besar perusahaan manufaktur akan berisi akun-akun sama seperti pada akun-akun buku besar jenis 
perusahaan lainnya dengan penambahan akun biaya. Pada saat transaksi dicatat, biaya manufaktur akan mengalir akun-akun secara paralel dengan aliran sumber daya melalui proses produksi. Sistem akuntansi biaya akan berbeda dalam elemen-elemen biaya yang dimasukkan dalam biaya produk dan bagaimana elemen-elemen biaya tersebut dilakukan pengukuran. Dengan menyesuaikan aturan pelaoran eksternal mengharuskan menerapkan biaya penyerapan penuh aktual. Dan untuk mengakumulasikan biaya secara jamak digunakan sistem perhitungan biaya berdasarkan pesanan, sistem perhitungan biaya berdasarkan proses dan campuran antara keduanya.

\section{Soal Diskusi}

1. Apa saja lima komponen dari bagian harga pokok penjualan dalam laporan laba rugi?

2. Apabila sebuah perusahaan menggunakan perhitungan biaya berdasarkan pesanan dengan penyerapan biaya penuih aktual, maka atribut-atribut apa saja yang terdapat dalam sistem akuntansi biaya?

3. Bedakan metode perhitungan biaya berdasarkan pesanan dan metode perhitungan biaya berdasarkan proses.

4. Berikan contoh bidang industri apa saja yang menggunakan sistem perhitungan biaya berdasarkan pesanan.

5. Apa keunggulan sistem manufaktur flexibel?

\section{Soal Perhitungan dan Analisa}

1. Amman Company mengumpulkan informasi berkaitan dengan operasinya di bulan Mei 2016 (dalam ribuan rupiah). Berikut data biayanya: 
Barang dalam proses, saldo awal

Barang jadi, saldo akhir 900

Bahan baku langsung yang digunakan $\quad 3000$

Tenaga kerja langsung 600

Barang dalam proses, saldo akhir 2100

Overhead pabrik 800

Barang jadi, saldo awal 340

Hitunglah harga pokok penjualan Amman Company pada akhir Mei 2016.

2. Anarghya Manufacturing selama bulan Juni memiliki transaksi sebagai berikut (dalam ribuan):

a. Bahan baku dibeli Rp 40.000,--

b. Bahan baku dimasukkan dalam produksi Rp 33.000,dan untuk bahan penolong Rp 2.000,--

c. Total beban gaji sebesar $\mathrm{Rp} 40.000$,-

d. Pembayaran beban gaji.

e. Dari total beban gaji Rp 32.000,- merupakan biaya tenaga kerja langsung dan $\mathrm{Rp}$ 8.000,- merupakan tenaga kerja tidak langsung.

f. Biaya overhead sebesar Rp 22.000,-

g. Overhead lain-lain sebesar Rp 2.100,- untuk penyusutan, asuransi $\mathrm{Rp} 780,-$, pajak properti $\mathrm{Rp}$ 1.250,--.

h. Total overhead pabrik dibebankan ke perkiraan barang dalam proses.

i. Prosuk selesai dan ditransfer ke gudang Rp 92.000,--

j. Penjualan secara kredit sebesar Rp 80.000,-. Harga pokok penjualan sebesar $75 \%$ dari harga jual.

Diminta:

1. Jurnal untuk setiap transaksi yang muncul. 
2. Masukkan dalam buku besar.

3. Buat laporan laba rugi. 


\section{BAB 5}

\section{SISTEM PERHITUNGAN BIAYA BERDASARKAN PESANAN}

Telah dijelaskan secara singkat di dalam Bab 4 mengenai metode perhitungan biaya berdasarkan pesanan dan metode perhitungan biaya berdasarkan proses. Didalam bab ini akan menjelaskan metode perhitungan berdasarkan pesanan, serta mengupas tentang akumulasi biaya yang merupakan tujuan dari metode perhitungan biaya berdasarkan pesanan maupun metode perhitungan biaya berdasarkan proses.

\section{Pengertian dan Karakteristik Produk Berdasarkan Pesanan}

Pesanan merupakan output yang diidentifikasikan untuk memnuhi pesanan pelanggan tertentu maupun untuk mengisi kembali suatu item persediaan. Dalam sistem perhitungan biaya berdasarkan pesanan atau dengan istilah job order costing ini biaya produksi akan diakumulasikan secara terpisah. Yang berbeda dengan sistem perhitungan biaya berdasarkan proses yang mengakumulasikan biayanya dengan menghitung biaya berdasarkan tiap-tiap operasi, departemen, maupun divisi dalam perusahaan.

Agar perhitungan biaya berdasarkan pesanan menjadi lebih efektif, maka pesanan harus dapat diidentifikasikan secara terpisah antara satu pesanan dengan pesanan lainnya. Dengan tujuan rincian biaya berdasarkan pesanan akan sesuai dengan sumber daya yang diperlukan. Sebagai contoh jika suatu percetakan secara menyeluruh mempersiapkan label, kertas berwarna, gambar tempel, maka selain pesanan-pesanan tersebut akan dapat mudah dibedakan berdasarkan tampilan fisiknya. 
Rincian untuk biaya berdasarkan pesanan akan dicatat secara detail dalam kartu biaya pesanan (job cost sheet), dapat berbentuk kertas maupun sistem elektronik. Walaupun berbagai macam pesanan dikerjakan dalam waktu yang bersamaan setiap kartu biaya pesanan akan mengumpulkan rincian biaya untuk satu pesanan saja. Isi dan pengaturan biaya pesanan disesuaikan karakteristik masing-masing bisnis. Gambar 5-1 merupakan contoh dari kartu biaya pesanan. Pada bagian atas merupakan kolom untuk mencatat nama pemesan, spesifikasi pesanan, jumlah pesanan, nomor pesanan, mulai pengerjaan dan penyelesaian pesanan. Bagian berikutnya adalah rincian biaya untuk bahan baku langsung, biaya tenaga kerja langsung dan overhead pabrik yang dibebankan ke dalam pesanan tersebut.

\begin{tabular}{|c|c|c|c|}
\hline \multicolumn{4}{|c|}{ PT Makmur } \\
\hline \multicolumn{4}{|c|}{ JI Subur Surabaya } \\
\hline & & No Pesanan & : \\
\hline \multicolumn{4}{|c|}{ Kartu Biaya Pesanan } \\
\hline Konsumen & : & Tgl Dipesan & : \\
\hline Produk & : & Tgl Dikerjakan & : \\
\hline Spesifikasi & : & Tgl Selesai & : \\
\hline \multicolumn{4}{|c|}{ Bahan Baku Langsung } \\
\hline Tanggal & Nomor & Permintaan & Jumlah \\
\hline \multicolumn{4}{|c|}{ Tenaga Kerja Langsung } \\
\hline Tanggal & Jam & Biaya & Jumlah \\
\hline \multicolumn{4}{|c|}{ Overhead Pabrik } \\
\hline Tanggal & $\begin{array}{c}\text { Jam } \\
\text { Mesin }\end{array}$ & Biaya & Jumlah \\
\hline \multicolumn{3}{|c|}{ Total Biaya } & \\
\hline
\end{tabular}


Perhitungan biaya berdasarkan pesanan mengakumulasikan biaya bahan baku langsung, biaya tenaga kerja langsung dan biaya overhead yang dibebankan dalam tiap pesanan. Yang akan memberikan pandangan bahwa perhitungan biaya berdasarkan pesanan memiliki tiga bagian yang saling berhubungan. Akuntansi bahan baku akan melakukan pencatatan persediaan bahan baku, keudian membebankan bahan baku langsung ke dalam pesanan, dan membebankan bahan baku tidak langsung ke dalam akun overhead.

Untuk akuntansi tenaga kerja akan melakukan pencatatan terhadap akun-akun yang memiliki hubungan dengan beban gaji dan kemudian membebankan tenaga kerja langsung kepada pesanan dan tenaga kerja tak langsung kepada akun overhead pabrik. Selanjutnya kaun overhead akan mengakumulasikan biaya overhead, dan melakukan pencatatan secara terperinci atas overhead dan membebankan sebagian dari overhead kedalam setiap pesanan. Untuk masing-masing transaksi yang terjadi dalam perhitungan biaya berdasarkan pesanan terdapat delapan tipe ayat jurnal untuk setiap item, yaitu:

1. Pembelian bahan baku

2. Pengakuan biaya tenaga kerja pabrik

3. Pengakuan biaya overhead pabrik

4. Penggunaan bahan baku

5. Distribusi beban gaji tenaga kerja

6. Pembebanan estimasi biaya overhead

7. Penyelesaian pesanan

8. Penjualan produk

Untuk tipe ayat jurnal 1 sampai dengan 3 adalah ayat jurnal yang umumbaik untuk perhitungan biaya berdasarkan pesanan maupoun 
untuk perhitungan biaya berdasarkan proses. Untuk tipe ayat jurnal yang ke 4 hingga ke 7 adalah ikhtisar untuk akhir suatu periode. Dan untuk ayat jurnal tipe 8 adalah tujuan akhir dari proses perhitungan biaya berdasarkan pesanan yaitu penjualan.

\section{Akuntansi Bahan Baku}

Dalam akun persediaan di buku besar untuk bahan baku langsu, bahan baku tidak langsung dan perlengkapan dapat dipisah. Akan tetapi secara umum perusahaan menggunakan satu akun buku besar Bahan Baku. Untuk alur akuntansi bahan bahu dijelaskan sebagai berikut.

\section{Pembelian Bahan Baku}

Untuk sistem akuntansi biaya dalam transaksi pembelian bahan baku sama dengan akuntansi untuk bahan baku dengan menggunakan sistem persediaan perpektual. Pasa saat bahan baku telah diterima, maka nilainya akan didebit dalam akun Bahan Baku. Manggala Company menerima faktur pembelian bahan baku senilai Rp 25.000.000,- untuk bahan baku yang dibeli tanggal 8 Juni. Ayat jurnal transaksi tersebut adalah:

Bahan Baku

Utang Usaha
Rp $\quad 25.000 .000,00$

Rp 25.000.000,00

Kuantitas dan harga tiap unit pada setiap pembelian dicatat dalam kartu catatan bahan baku. Satu bahan baku menggunakan satu kartu sebagai pengendalian bahan baku. Fungsi kartu tersebut untuk mencatat persediaan secara perpektual dan sekaligus sebagai buku pembantu untuk mendukung akun bahan baku. 


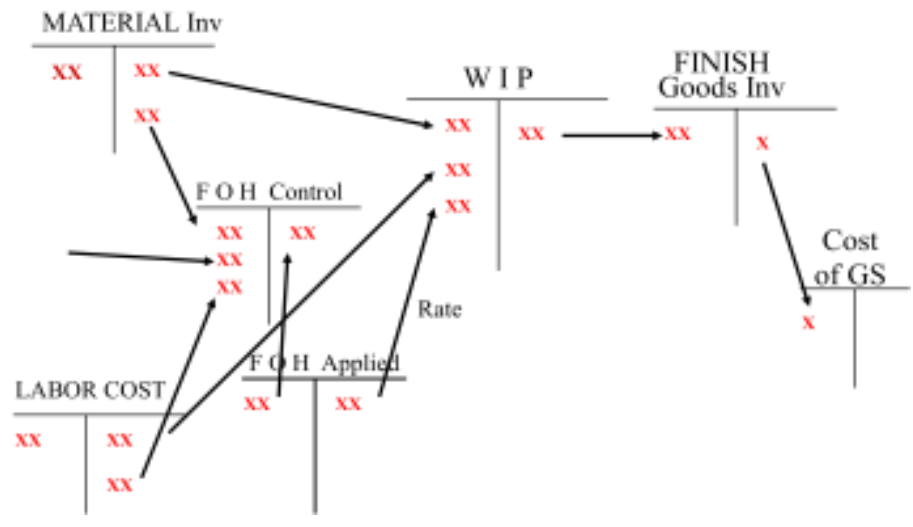

Gambar 5-1 Alur Biaya Produksi (Manufacturing Cost Flows)

\section{Penggunaan Bahan Baku}

Bahan baku langsung untuk suatu pesanan akan dikeluarkan ke proses produksi berdasarkan atas bukti permintaan bahan baku (material requisitions). Bukti dokumen ini akan dibuat oleh staf yang menyusun jadwal produksi ataupun personel lain yang berisi spesifikasi mengenai nomor pesanan, spesifikasi dan jumlah bahan baku yang dibutuhkan. Terdapat satu penggandaan dari bukti permintaan yang dikirim ke gudang dan akan mengumpulkan item tersebut. Setiap kuantitas dan biaya dari setiap item akan dicatat dalam bukti permintaan bahan baku dan diposting ke kartu catatan bahan baku.

Selanjutnya aliran bahan baku dari dalam gudang dipindah ke pabrik maka pertanggung jawaban biaya sebagai transfer biaya dari Bahan Baku ke Barang Dalam Proses. Acap kali dilakukan dalam bentuk ikhtisar dalam pada akhir periode. Dengan jurnal sebagai berikut. 
Barang Dalam

Proses Rp $10.000 .000,00$

Bahan Baku

Rp $10.000 .000,00$

Satu salinan dari setiap bukti permintaan bahan baku dikirimkan ke dalam departemen biaya diaman semua salinan bukti akan diurutkan sesduai dengan nomor pesanan dan dan dicatat. Dengan metode ini, jumlah kuantiotas bahan baku serta biaya bahan baku akan tercatat dalam kartu biaya pesanan setiap hari, minggu atau sesuai penyelesaian produk sehingga biaya dapat diakumulasikan dengan tepat waktu. Di pihak lain jurnal tidak dibuat sesering memasukkan dalam kartu bahan baku. Apabila terdapat bahan baku yang tidak digunakan untuk pesanan maka akan dikembalikan ke dalam gudang dengan mengkreditkan akun bahan baku dan akun barang dalam proses, serta melakukan penyesuaian untuk kartu biaya pesanan.

Berkas bukti permintaan bahan baku juga dipergunakan untuk mengeluarkan bahan baku tidak langsung maupun perlengkapan yang dibutuhkan pesanan. Kemudian jika tidak digunakan di pabrik, akan tetapi dipakai oleh pemasaran maupun administrasi akan dimasukkan dalam akun biaya pemasaran dan administrasi. Sebaliknya jika dipergunakan untuk pesanan di pabrik maka bahan tidak langsung maupun perlengkapan tersebut akan dibebankan pada akun Pengendali Overhead Pabrik. Dengan jurnal sebagai berikut. 
Pengendali Overhead

Pabrik

Rp $5.000 .000,00$

Bahan Baku

Rp $\quad 5.000 .000,00$

Perhitungan dari rincian biaya overhead juga diposting dalam akun buku pembantu overhead, berupa kertas kerja yang disebut kertas kerja analisis overhead pabrik.

Sehingga informasi yang tepat waktu sangat dibutuhkan untuk menghitung biaya produk dan tagihan ke pelanggan. Untuk itu bukti permintaan bahan baku akan dimasukkan ke dalam kartu biaya pesanan dalam waktu satu minggu atau kurang untuk menghasilkan informasi biaya yang tepat waktu. Dengan perkembangan tehnologi dan munculnya sistem akuntansi yang telah terotomatisasi, bukti permintaan bahan baku dalam dilakukan secara elektronik, dan data di kartu biaya pesanan serta buku pembantu overhead dapat disesuaikan saat itu juga.

\section{Akuntansi Tenaga Kerja}

Telah banyak perusahaan menggunakan mesin waktu pencatatan kedatangan dan waktu pulang setiap karyawan baik dalam kartu absen maupun dengan sidik jari yang lebih akurat. Dengan adanya mesin absensi ini bak kartu absen maupun sidik jari telah menunjukkan jumlah kerja karyawan untuk menentukan penghasilannya.

Dalam membantu identifikasi biaya tenaga kerja langsung maupun tak langsung tiap-tiap karyawan dibuatkan satu atau dua sistem pencatatan. Yang satu untuk jam tenaga kerja sesuai dengan pengerjaan pesanan. Dan yang lain untuk memperhitungkan 
pekerjaan ataupun tugas lain diluar pesanan. Tenaga kerja yang tidak mengerjakan pesanan dimasukkan dalam akun beban administrasi dan beban pemasaran.

\section{Biaya Tenaga Kerja}

Dalam setiap periode pembayaran gaji, kewajiban untuk gaji dan pembayaran lainnya dicatat dalam jurnal dan diposting dalam buku besar. Dengan tidak memperdulikan jumlah kewajiban yang dicatat, maka lawan jurnalnya adalah dibagian debit ke Beban Gaji. Biaya tenaga kerja diakumulasikan secara sementara dan didistribusikan ke akun-akun biaya lainnya yang dilakukan tiap akhir periode.

Secara umum pembayaran upah karyawan dilaksanakan secara bulanan, walaupun bahkan ada yang melakukannya lebih sering mingguan atau bahkan harian. Sehingga akan melakukan pencatatan beberapa kali dalam satu bulan, mengakibatkan rincian akuntansi tenaga kerja menjadi sangat banyak. Dengan jurnal sebagai berikut.

Beban

Gaji
$\mathrm{Rp}$

$31.000 .000,00$

Beban Gaji yang

Masih Harus Dibayar

$\operatorname{Rp} 31.000 .000,00$

\section{Distribusi Biaya Tenaga Kerja}

Untuk mendistribusikan biaya tenaga kerja secara umum dilakukan secara periodik bulanan. Kartu jam kerja karyawan akan diurutkan berdasarkan pesanan kemudian dimasukkan ke dalam 
kartu biaya pesanan dan dicatat dalam jurnal umum. Dengan pengakuan jam tenaga kerja dalam pabrik otomatis dengan jumlah tenaga kerja yang amat sedikit dan satu klasifikasi biaya konversi, semua tenaga pabrik diberlakukan sama seperti tenaga kerja tidak langsung. Dengan jurnal masing-masing untuk tenaga kerja langsung dan tenaga kerja tak langsung sebagai berikut:

Barang Dalam

Proses

Rp $\quad 27.000 .000,00$

Beban

Gaji

Rp 27.000.000,00

Pengendali

Overhead

Rp $\quad 4.000 .000,00$

Beban

Gaji

Rp $\quad 4.000 .000,00$

Pencatatan jam kerja karyawan dengan menggunakan kartu jam karyawan diurutkan dan dicatat dalam kartu biaya pesanan secara mingguan maupun harian, dengan tujuan agar biaya produk dan tagihan kepada pemesan dapat diakumulasikan dengan segera. Sebaliknya dalam saldo buku besar hanya perlu dilakukan penyesuaian di setiap akhir bulan maupun kuartal pada saat laporan keuangan akan disusun. Untuk perusahaan yang telah memakai sistem otomatisasi akan melakukan identifikasi kartu jam kerja 
secara elektronik akan lebih mudah dimutakhirkan dengan segera bahkan seketika.

\section{Akuntansi Biaya Overhead Pabrik}

Semua biaya yang tidak dapat ditelusuri secara langsung dalam pesanan akan tetapi terjadi dalam proses produksi (tidak termasuk pemasaran dan administrasi) merupakan overhead pabrik. Jika terjadi kurang penelusuran langsung terhadap akutansi biaya overhead menjadi berbeda. Dan akan menjadi penyebab utama karena peranan yang paling utama adalah bukti permintaan bahan baku dan kartu jam tenaga kerja. Sehingga biaya overhead diakumulasikan tanpa mengacu kepada pesanan tertentu, dan total biaya overhead dialokasikan kepada seluruh pesanan.

\section{Biaya Overhead Aktual}

Biaya bahan baku tak langsung dan tenaga kerja tidak langsung yang merupakan biaya overhead aktual akan dicatat pada saat terjadinya melalu jurnal secara periodik. Sedangkan biaya overhead lainnya seperti penyusutan, asuransi akan dilakukan pencatatan pada akhir periode melalui jurnal penyesuaian. Dengan jurnal sebagai berikut: 
Pengendali Overhead

Pabrik

Rp 4.900.000,00

Akumulasi Penysutan Mesin

Rp 4.900.000,00

Pengendali Overhead

pabrik

$\operatorname{Rp} 520.000,00$

Asuransi Dibayar

Dimuka

Rp $520.000,00$

Untuk akun biaya tenaga kerja tidak langsung didalamnya terbagi menjadi beberapa bagian seperti kafetaria, pengriman bahan baku, kebersihan, pemeliharaan dan lain sebagainya, dimana masing-masing bagian dicatat secara terpisah dalam buku pembantu. Selain biaya tenaga kerja tidak langsung masih banyak lagi boaya overhead lainnya sebagai contoh adalah biaya sewa, asuransi gedung pabrik, pajak pabrik, depresiasi mesin, depresiasi pabrik, dan lain sebagainya. Untuk seluruh biaya overhead yang terjadi maka akun Pengendali Overhead Pabrik akan dimasukkan dalam debit dengan mencatat rincian buku pembantu, kemudian di sisi kredit mencatat aset yang sesuai ataupun akun kewajiban.

\section{Biaya Overhead yang Dialokasikan}

Biaya yang dibebankan untuk tiap-tiap pesanan adalah biaya bahan baku langsung dan biaya tenaga kerja langsung, sedangkan pembebanan biaya overhead pabrik untuk pesanan akan lebih rumit. Karena terdapat biaya-biaya yang tidak bergantung pada tingkat 
aktivitas maupun unit yang diproduksi seperti biaya penyusutan, biaya sewa, dan lain sebagainya.

Agar mempermudah pembebanan biaya overhead pabrik, maka seluruh biaya overhead pabrik akan dibebankan sesuai dengan proporsi dari tingkat aktivitas mauopun unit yang diproduksi oleh masing-masing pesanan. Pada saat terjadi peningkatan otomatisasi yang mengakibatkan penurunan tenaga kerja langsung, maka tidak akan menggunakan penelusuran aktivitas dengan dasar jam tenaga kerja langsung. Akan tetapi lebih memilih menggunakan jam mesin, jam proses.

Dasar alokasi overhead yang digunakan sebagai dasar pembebanan biaya overhead sebaiknya dipilih berdasarkan aktivitas yang paling berkaitan dengan biaya yang akan dialokasikan. Apabila tidak terdapat satu dasar alokasi yang dapat dipilih, maka beberapa dasar alokasi yang mendukung satu kegiatan dapat dipilih dan dipergunakan sebagai dasar alokasi.

Tarif overhead merupakan total overhead yang telah diakumulasikan dibagi dengan total dasar alokasi, disebut dengan istilah overhead rate. Terdapat beberapa overhead yang tidak bisa secara langsung dialokasikan kepada pesanan karena harus menunggu dalam satu periode bulanan bahkan tahunan, sehingga tidak bisa memperhitungkan biaya overhead yang akan dibebankan secara segera kedalam pesanan, maka perusahaan perlu melakukan estimasi terhadap overhead tersebut agar biaya pesanan dapat diperhitungkan tepat waktu. Istilah tarif overhead yang telah ditentukan sebelumnya (predetermined overhead rate) menggunakan rasio dari estimasi total overhead terhadap estimasi total dasar alokasi overhead. Untuk jumlah overhead yang 
dibebankan ke suatu pesanan disebut sebagai overhead dibebankan (applied overhead).

Untuk seluruh overhead yang dibebankan ke semua pesanan yang dikerjakan selama satu periode didebit ke akun Barang Dalam Proses pada akhir periode. Untuk sisi kredit akan dicatat akun Pengendali Overhead Pabrik. Dengan jurnal sebagai berikut:

Barang

Dalam Proses

$\operatorname{Rp} 13.200 .000,00$

Overhead

Pabrik

Rp 13.200.000,00

Dibebankan

Setelah dibebankan dalam biaya produksi akan ditutup ke Pengendali Overhead. Dengan jurnal sebagai berikut:

Overhead

Pabrik

Dibebankan

$\operatorname{Rp} 13.200,00$

Pengendali

Overhead

Pabrik

Rp $13.200,00$ 
Overhead harus memiliki akun tersendiri dengan tujuan mempermudah catatan overhead dibebankan dan overhead aktual. Dengan adanya catatan yang terpisah manajemen lebih m,udah dalam pemgambilan keputusan. Dengan mengevaluasi dengan tarif overhead dan membandingkannya antar total overhead dibebankan dan total overhead aktuap sesuai dengan jumlah yang dianggarkan. Untuk perusahaan yang tidak menggunakan akun overhead pabrik dibebankan akan mengkreditkan Pengendali Overhead Pabrik pada saat mendebit Barang Dalam Proses. Hal ini dilakukan untuk meniadakan jurnal penutup dan memiliki akumulasi akhir jurnal yang sama pada Pengendali Overhead Pabrik.

Jika terjadi overhead yang dibebankan terlalu rendah akan diinterpretasikan sebagai varian biaya yang tidak menguntungkan. Saldo overhead yang dibabnkan terlalu rendah ataupun terlalu tinggi perlu dipertimbangkan signifikansinya. Bila saldo akhir tahun kecil maka saldo akhir akan ditransfer ke Harga Pokok Penjualan dan mengkreditkan Pengendali Overhead Pabrik.

\section{Akuntansi Barang Jadi dan Produk Dijual}

Saat terselesaikannya suatu produk pesanan, kartu biaya pesanan akan berubah kategorinya menjadi pekerjaan ataupun pesanan yang sudah selesai. Untuk mencatat pesanan yang sudah selesai dan mengisi kembali persediaan barang jadi, maka nilkai kuantitas dan biayanya dicatat pada kartu barang jadi sebagai akun buku pembantu untuk mendukung akun barang jadi. 
Pesanan yang telah selesai dikerjakan, dapat dikirim langsung kepada pelanggan sehingga tidak melakukan pencatatan dalam akun persediaan barang jadi. Penjualan dan Harga Pokok Penjualan dicatat pada saat pesanan ditransfer ke Barang Dalam Proses. Untuk pesanan yang tidak dikirim langsung akan ditransfer Barang Jadi. Dengan jurnal sebagai berikut:

Jurnal produk langsung dikirim saat selesai pengerjaan.

Piutang Usaha

Penjualan

Harga Pokok Penjualan

Barang Dalam

Proses
$\operatorname{Rp} 7.860 .000,00$

Rp 7.860.000,00

Rp 5.254.000,00

Jurnal pesanan jadi dan ditransfer ke barang jadi untuk mengisi persediaan.

Barang Jadi

Rp56.926.000,00

Barang Dalam

Proses

Rp56.926.000,00

Namun jika suatu pesanan selesai dikerjakan akan tetapi untuk mengisi kembali persediaan suatu komponen untuk membuat 
produk lain, maka biaya dari pekerjaan tersebut akan dibebankan ke akun Bahan Baku.

Pada saat persediaan dikirim kepada pelanggan, kartu pesediaan barang jadi dimutakhirkan, faktur penjualan dibuat, penjualan dan harga pokok penjualan dibukukan sesuai dengan sistem persediaan perpectual. Dengan jurnal sebagai berikut:

Piutang Usaha

Penjualan

Harga Pokok

Penjualan
Rp $70.000 .000,00$

$\operatorname{Rp} 70.000 .000,00$

Rp $\quad 52.300 .000,00$

Barang Jadi

Rp 52.300.000,00

\section{Sistem Perhitungan Biaya Berdasarkan Pesanan Untuk Produk Jasa}

Untuk perusahaan jasa ketika pesanan yang satu berbeda dengan pesanan lainnya dan informasi biaya yang tersedia diinginkan untuk tiap-tiap pesanan, maka akan terdapat beberapa variasi dari perhitungan biaya berdasarkan pesanan yang akan digunakan. Dalam bisnis jasa, tenaga kerja langsung dan biaya lain yang berhubungan dengan tenaga kerja akan lebih besar nilainya dibandingkan dengan biaya-biaya lainnya, bahkan dengan selisih yang cukup jauh. Merupakan hal yang umum untuk mengkombinasikan biaya tenaga kerja dengan tarif overhead yang 
telah ditentukan sebelumnya agar jumlah biaya yang dibebankan dalam tiap pesanan sudah termasuk biaya tenaga kerja dan overhead.

Item yang tertinggal untuk dilakukan pembebanan ke dalam pesanan adalah biaya yang secara langsung berkenaan dengan pesanan selain tenaga kerja, seperti biaya suku cadang, biaya perjalanan, fotokopi dan lain sebagainya. Untuk melakukan penelusuran terhadap biaya tersebut, perusahaan memakai metode dengan mengakumulasi biaya perjalanan, dan lain-lain yang telah dikeluarkan oleh karyawan mengganti bukti pengeluaran dengan uang tunai.

Sedangkan untuk menelusuri catatan telepon maka karyawan harus melakukan pencatatan terhadap waktu dan intensitas telepon. Selamnjutnya biaya-biaya tersebut diakumulasikan dan dicatat dalam kartu biaya pesanan, yang dapat disebut berbeda sesuai dengan jenis bisnis dan aktivitasnya. Perbedaan dengan perusahaan manufaktur, dalam perusahaan jasa biaya overhead tidak terpisah karena telah diestimasi dan ditentukan sebelumnya untuk taif per jam tenaga kerja.

\section{Soal Diskusi}

1. Apa tujuan dari perhitungan biaya berdasarkan pesanan?

2. Apa manfaat mempergunakan kartu biaya pesanan dalam mengakumulasi biaya?

3. Apakah yang membedakan antara overhead aktual dengan overhead yang dibebankan?

4. Bagaimana pengendalian dilakukan atas biaya utama dalam perhitungan biaya berdasarkan pesanan? 


\section{Soal Perhitungan}

1. Bulan Mei, Sweet Company menggunakan bahan baku senilai $\mathrm{Rp}$ 50.000.000,00 untuk produksi. Departemen Penggilingan menggunakan 5.000 jama tenaga kerja langsung dengan biaya $\mathrm{Rp}$ 10.000,00 per jam. Overhead pabrik dibebankan dengan tarif Rp 8.000,00 per jam tenaga kerja langsung di Departem,en Penggilingan dan $\mathrm{Rp}$ 11.000,00 per jam tenaga kerja langsung di Departemen Mesin. Akun persediaan memiliki saldo awal dan saldo akhir sebagai berikut:

Awal

Akhir

Bahan Baku

$\mathrm{Rp} \quad \mathrm{Rp}$

Langsung

$25.000 .000,00$

$19.000 .000,00$

Barang Dalam

$\mathrm{Rp}$

$\mathrm{Rp}$

Proses

$18.000 .000,00$

19.700.000,00

Barang Jadi

$\mathrm{Rp}$

$\mathrm{Rp}$

20.000.000,00

$18.500 .000,00$

Diminta: Tanpa membuat Laporan Laba Rugi
a. Total biaya untuk pesanan dalam proses.
b. Biaya dari pesanan selesai.
c. Biaya dari pesanan yang dijual.
d. Biaya bahan baku yang dibeli. 


\title{
SISTEM PERHITUNGAN BIAYA BERDASARKAN PROSES
}

\begin{abstract}
Dalam bisnis manufaktur biaya produksi yang diakumulasikan untuk mengetahui nilai jual sutu produk dipertanggungjawabkan dalam dua jenis sistem akumulasi biaya. Yaitu sistem perhitungan biaya berdasarkan pesanan (job order costing) dan sistem perhitungan biaya berdasarkan proses (process costing). Dalam bab ini akan dibahas sistem perhitungan biaya berdasarkan proses dengan dilengkapi jurnal umum untuk melengkapi pencatatan yang diperlukan dalam proses akumulasi biaya.
\end{abstract}

\section{$\underline{\text { Akumulasi Biaya Proses }}$}

Menentukan nilai biaya baik dari barang maupun jasa yang dihasilkan oleh perusahaan merupakan tujuan penting sistem perhitungan biaya. Sistem perhitungan biaya yang dipergunakan seharusnya ekonomis untuk dioperasikan dengan membebankan sejmlah biaya ke dalam setiap produk sedemikian rupa sehingga akan mencerminkan pemakaian biaya secara wajar dari sumber daya yang dipergunakan untuk menghasilkan produk tersebut. Setiap perusahaan akan memiliki perbedaan yang cukup kompleks baik dari struktur organisasi produksi, teknologi manufaktur yang dipergunakan, bauran produk yang dihasilkan yang akan membuat 
sistem perhitungan biaya berbeda antara satu perusahaan dengan perusahaan lainnya.

Untuk perhitungan biaya berdasarkan proses akan memperhitungkan biaya untuk produk yang dihasilkan dalam pusat biaya yang serupa (homogen). Biaya bahan baku, biaya tenaga kerja langsung dan biaya overhead pabrik akan dibebankan pada pusat biaya. Biaya akan dibebankan ke tiap unit yang ditentukan dengan membagi total biaya yang dibebankan kepada pusat biaya dengan total unit yang diproduksi. Pusat biaya biasanya adalah departemen, divisi,dan lain sebagainya. Persyaratan utama untuk sistem biaya berdasarkan proses adalah semua produk yang diproduksi dalam suatu periode yang sama dalam hal sumber daya yang dikonsumsi.

\section{Perhitungan Biaya Departemen}

Di perusahaan manufaktur bisa jadi terdapat lebih dari satu departemen. Dimana setiap departemen melakukan aktivitas operasi tertentu untuk penyelesaian produk. Departemen pertama melakukan proses pada tahap permulaan seperti memotong, membentuk komponen. Jika pekerjaan di departemen pertama selesai akan ditransfer ke departemen kedua. Departemen kedua akan melaksanakan tugasnya seperti penghalusan, pengecatan selanjutnya akan mentransfer unit-unit tersebut ke departemen selanjutnya, terus menerus hingga sampai ke gudang produk jadi.

Dalam sistem perhitungan biaya berdasarkan proses untuk biaya bahan baku langsung, biaya tenaga kerja langsung dan biaya overhead dibebankan ke departemen produksi. Dan jika departemen dibagi dalam dua pusat biaya atau lebih maka perhitungan biaya 
berdasarkan proses akan tetap digunakan dengan syarat unit-unit yang dihasilkan dalam pusat biaya bersifat homogen. Kriteria utama dalam perhitungan biaya berdasarkan proses adalah identifikasi atas unit bisnis yang memproduksi hanya satu jenis produk.

Karena lebih praktis dipergunakan perhitungan biaya berdasarkan proses, maka perusahaan lebih menyukai dibandingkan memakai perhitungan biaya berdasarkan pesanan. Faktor yang mengakibatkan lebih disukainya perhitungan biaya berdasarkan proses adalah biaya proses membutuhkan pencatatan yang lebih sedikit dan lebih sederhana dibandingkan biaya pesanan. Disamping itu bila pencatatan lebih sedikit dan sederahana, maka biaya perhitungan biaya berdasarkan pesanannnya akan lebih efisien.

Dalam biaya berdasarkan pesanan memiliki beberapa catatan untuk satu kartu biaya pesanan, sehingga akan banyak sekali catatan. Sedangkan untuk biaya berdasarkan proses hanya membutuhkan satu catatan terpisah untuk masing-masing departemen.

Perhitungan biaya berdasarkan proses dipergunakan untuk memperhitungkan produk yang dihasilkan secara kontinyu ataupun produksi secara masal, dimana produk yang dihasilkan bersifat homogen.

\section{Aliran Produksi}

Aliran produksi atau lebih dipahami sebagai perpindahan produk dalam proses produksi di dalam pabrik terdapat berbagai macam cara. Beberapa cara tersebut antara lain berurutan, paralel dan selektif. Selanjutnya kan dijelaskan sebagai berikut. 


\section{Aliran Produk Berurutan (Sequential Product Flow)}

merupakan aliran produk berurutan, dimana setiap produk mendapatkan perlakuan secara berurutan dengan langkah-langkah yang sama. Sebagai contoh dengan departemen pemotongan, pencampuran dan pengepakan.

Proses produksi dimulai dari Departemen Pemotongan dimana bahan baku dikombinasikan dengan tenaga kerja langsung dan overhead yang ditambahkan. Setelah pengerjaan di Departemen Pemotongan selesai akan ditrasnfer ke Departemen Pencampuran dimana terjadi penambahan biaya tenaga kerja langsung dan biaya overhead. Selanjutnya pekerjaan Departemen Pencampuran yang telah selesai akan ditransfer ke Departemen Pengepakan yang terjadi penambahan biaya tenaga kerja langsung dan biaya overhead pabrik. Dimungkinkan adanya penambahan biaya bahan baku langsung. Setelah proses di Departemen Pengepakan selesai maka produk-produk tersebut akan ditransfer ke persediaan barang jadi untuk disimpan hingga dibeli oleh konsumen.

\section{Aliran Produk Paralel (Parallel Product Flow) yang} melakukan proses produksi secara paralel yaitu satu epartemen melakukan proses produksi secara simultan kemudia disatukan dalam satu proses untuk diselesaikan dan dikirim ke barang jadi.

Sebagai contoh perusahaan kursi berbahan kain dan besi, di Departemen Pemotongan memproses besi sesuai potongan yang diinginkan, secara bersamaan Departemen Jok memproses sandaran dan dudukan kursi berbahan kain dan busa. Setelah selesai dari Departemen Pemotongan dan Departemen Jok akan ditransfer ke Departemen Perakitan untuk menyatukan rangka Besi dan Jok yang 
telah selesai dari Departemen sebelumnya ditambahkan denga bahan baku, tenaga kerja langsung dan overhead. Setelah penyelesaian akan dikirm ke persediaan produk jadi.

Aliran Produk Selektif (Selective Product Flow)untuk aliran produk selektif ini produk akan berpindah-pindah ke departemendepartemen yang berbeda dalam suatu pabrik, bergantung pada hasil produk akhir yang dihasilkan.

\section{Akuntansi Biaya Bahan Baku, Tenaga Kerja dan Overhead}

Walaupun pencatatan untuk sistem perhitungan biaya berdasarkan proses lebih sedikit dibandingkan dengan sistem perhitungan biaya pesanan, konsep dasar yang dipergunakan dalam metode perhitungan biaya berdasarkan pesanan juga berlaku bagi perhitungan biaya berdasarkan proses. Yang menjadi pembeda antara dua sistem tersebut adalah sistem perhitungan biaya berdasarkan proses, biaya dibebankan pada departemen atau pusat biaya. Sedangkan sistem perhitungan biaya berdasarkan pesanan akan membebankan biaya kepada pesanan yang sesuai.

\section{Biaya Bahan Baku}

Dalam biaya berdasarkan proses bukti permintaan barang merupakan alat pengendalian bahan baku, apabila bahan baku tidak diberikan nilai secara individual maka biaya bahan baku akan ditentukan di akhir periode. Dengan menambahkan saldo awal dan pembelian kemuadian mengurangkan dengan persediaan akhir. 
Sebagai comtoh sebuah perusahaan yang memiliki dua departemen produksi yaitu Departemen Pemotogan dan Departemen Penghalusan melakukan proses produksi. Maka ayat jurnal umum yang mendukung adalah sebagai berikut:

Barang dalam Proses-Departemen

Pemotongan

Rp13.500.000,00

Barang dalam Proses-Departemen

Penghalusan

Rp 7.200.000,00

Bahan Baku

Rp20.700.000,00

\section{Biaya Tenaga Kerja}

Biaya tenaga kerja dalam sistem perhitungan biaya berdasarkan proses lebih mudah penelusurannya diabndingkan sistem perhitungan biaya berdasarkan pesanan, dimana untuk biaya pesanan tenaga kerja dihitung sesuai dengan kartu jam kerja dan dialokasikan ke masingmasing pesanan. Sedangkan untuk biaya proses hanya menelusuri kartu jam kerja harian atau absensi yang digunakan untuk menghitung biaya tenaga kerja. Dengan jurnal yang mendukung sebagai berikut:

Barang dalam Proses-

Departemen Pemotongan $\quad$ Rp 5.000.000,00

Barang dalam Proses-

Rp $8.000 .000,00$ 
Departemen Penghalusan

Beban Gaji

Rp 13.000.000,00

\section{Biaya Overhead Pabrik}

Untuk perhitungan overhead pabrik baik bagi sistem biaya pesanan maupun sistem biaya proses keduanya sama yaitu melakukan akumulasi biaya overhead kepadaakun buku besar pengendali, dengan rincian tiap-tiap biaya overhead pabrik diakumulasikan dalam buku pembantu yang mendukung buku besar. Dalam buku pembantu setiap item biaya overhead akan diperinci hingga ke jumlah biaya per departemen. Hasil informasi yang terperinci akan dipergunakan untuk perencanaan biaya di periode yang akan datang dan dipergunakan untuk pengendalian biaya overhead pabrik. Ayat jurnal pembebanan biaya overhead pabrik adalah sebagai berikut:

Pengendali Overhead Pabrik Rp 16.500.000,00

Utang Usaha

Rp7.000.000,00

Akumulasi

Penyusutan

Rp5.000.000,00

Asuransi Dibayar di

Muka

Rp1.000.000,00

Bahan Baku (tak

langsung)

Rp2.000.000,00

Beban Gaji (tak

langsung)

Rp1.500.000,00 
Karena biaya aktual overhead pabrik akan berbeda pada tiap periodenya dan tidak bersifat variabel sempurna terhadap aktivitas produksi, maka tarif overhead yang telah ditetapkan sebelumnyaakan dipergunakan untuk melakukan rerata biaya overhead secara proporsional terhadap aktivitas produksi selama tahun tersebut. Overhead pabrik dibebankan ke departemen produksi dalam akhir periode untuk menentukan biaya produksi dalam periode tersebut. Akan tetapi jika pembebanan overhead menggunakan tarif overhead yang telah ditentukan sebelumnya, maka jumlah tersebut akan dikalikan dengan jumlah aktual yang dipergunakan dalam setiap departemen produksi. Dengan ayat jurnal umum sebagai berikut:

Barang dalam Proses-

Departemen Pemotongan $\quad$ Rp 8.200.000,00

Barang dalam Proses-

Departemen Penghalusan $\quad \mathrm{Rp} 10.400 .000,00$

Beban Gaji

Rp 18.600.000,00

\section{Laporan Biaya Produksi}

Perhitungan biaya berdasarkan pesanan akan mengakumulasi seluruh biaya dalam suatu departemen dan diikhtisarkan dalamlaporan biaya produksi departemen. Laporan biaya produksi (cost of production report)merupakan kertas kerja yang menampilkan julah biya yang diakumulasikan dan dibebankan 
ke produksi selama satu bulan atau periode lainnya. Laporan biaya produksi tersebut juga merupakan sumber informasi untuk menyusun ayat jurnal guna mencatat biaya dari unit yang ditransfer dari satu departemen produksi ke departemen produksi lainnya hingga ke persediaan barang jadi.

Format laporan biaya produksi untuk suatu departemen terdiri atas (a) Biaya total dan biaya per unit dari pekerjaan yang dilakukan, (b) biaya total dan biaya per unit bahan baku, tenaga kerja, dan overhead pabrik yang ditambahkan dalam departemen tersebut; (c) biaya persediaan awal dan akhir barang dalam proses (d) biaya yang ditransfer ke departemen berikutnya atau persediaan barang jadi. Dalam format laporan biaya berdasarkan proses dibagi menjadi dua bagian yaitu biaya yang harus dipertanggungjawabkan dan biaya ditransfer keluar hingga ke produk jadi. Total di bagian pertama harus sama dengan total di bagian kedua. Laporan biaya produksi juga memasukkan skedul kuantitas, yang menunjukkan total jumlah unit yang harus dipertanggungjawabkan oleh departemen dan dialokasikan ke unit-unit tersebut.

Untuk menentukan biaya dari unit-unit yang ditrasfer keluar dari departemen satu ke departemen lainnya dan terdapat biaya yang masih tersisa dalam bentuk persediaan akhir merupaka suatu proses alokasi. Sehingga biaya-biaya akan dapat berubah sejalan berlalunya waktu dan dibutuhkan asumsi aliran biaya. Asumsi aliran biaya yang paling umum dipergunakan adalah perhitungan biaya rata-rata tertimbang.

Selanjutnya karena tiap unit yang diproduksi belum merupakan produk jadi maka diperhitungkan dalam unit ekuivalen (equivalent unit) merupakan jumlah dari sumber daya yang diperlukan dalam menyelesaikan satu unit produk. Sumber daya 
yang diperlukan adalah bahan baku langsung, tenaga kerja langsung dan overhead pabrik. Bila dalam memproduksi satu unit diperlukan 4 bahan baku maka 1 unit dengan kebutuhan 4 bahan baku merupakan 1 unit ekuivalen bahan baku. Sehingga unit ekuivalen merupakan unit hipotesis bukan unit fisik.

Untuk mempermudah ilustrasi biaya maka asumsikan Star Manufacturing menggunakan sistem perhitungan buaya berdasarkan proses dengan aliran biaya rata-rata tertimbang. Data produksi yang tersedia untuk periode bulan Juni:

Barang dalam Proses, persediaan awal

100

180

Unit dimulai di Departemen

Pencampuran 600

Unit ditransfer ke Departemen

Pengemasan 500

Unit diterima dari Departemen

Pencampuran 500

Unit Ditransfer ke Persediaan

Barang Jadi

580

Barang dalam Proses, persediaan akhir

Pencampuran Pengemasan 
Untuk overhead pabrik persediaan akhir di Departemen Pencampuran sebesar $40 \%$ dan di Departemen Pengemasan $70 \%$ selesai.

Data biaya produksi dalam bulan Juni sebagai berikut: (dalam ribuan)

\section{Pencampuran Pengemasan}

Barang dalam Proses, persediaan awal:

$\begin{array}{lll}\begin{array}{l}\text { Biaya dari } \\ \text { deoartemen }\end{array} & \mathrm{Rp} & \mathrm{Rp} \\ \text { sebelumnya } & - & 8.320,00 \\ & \mathrm{Rp} & \mathrm{Rp} \\ \text { Bahan Baku } & 1.892,00 & 830,00 \\ & \mathrm{Rp} & \mathrm{Rp} \\ \text { Tenaga Kerja } & 400,00 & 475,00 \\ & \mathrm{Rp} & \mathrm{Rp} \\ \text { Overhead Pabrik } & 796,00 & 518,00\end{array}$

Biaya yang ditambahkan ke proses selama periode berjalan:

$\begin{array}{lll} & \mathrm{Rp} & \mathrm{Rp} \\ \text { Bahan Baku } & 13.608,00 & 7.296,00 \\ & \mathrm{Rp} & \mathrm{Rp} \\ \text { Tenaga Kerja } & 5.000,00 & 9.210,00 \\ & \mathrm{Rp} & \mathrm{Rp} \\ \text { Overhead Pabrik } & 7.904,00 & 11.052,00\end{array}$

Tahap pertama dalam pembebanan biaya adalah menentukan jumlah unit ekuivalen untuk setiap erlemen biaya dan menghitung biaya dari setiap unit ekuivalen. Karena Star Manufacturing menggunakan aliran biaya rata-rata tertimbang, maka setiap unit ekuivalen termasuk biaya dari persediaan awal dan ditambahkan dengan biay dari oeriode berjalan. Rata-rata 
tertimbang setiap unit ekuivalen dipergunakan untuk membagi setiap total biaya dari masing-masing elemen biaya.

Untuk unit yang ditransfer dari Departemen Pencampuran ke Departemeb Pengemasan adalah $100 \%$ selesai untuk semua elemen biaya yang ditambahkan di Departemen Pencampuran (500 unit ekuivalen bahan baku, tenaga kerja dan overhead). Persediaan akhir Dertemen Pemotongan adalah 60\% bahan baku (200 unity $x$ $60 \%$ selesai $=120$ unit ekuivalen), $20 \%$ selesai tenaga kerja ( 200 unit x $20 \%=40$ unit ekuvalen tenaga kerja), dan $40 \%$ selesai overhead pabrik (200 unit x 40\% = 80 unit ekuivalen). Dengan perhitungan sebagai berikut:

$\underline{\text { Bahan }} \quad \underline{\text { Tenaga }}$ Kaku $\quad \underline{\text { Kerja }} \quad \underline{\text { Overhead }}$

Unit ekuivalen ditransfer

keluar

500

500

500

Unit ekuivalen

dipersediaan akhir

$\underline{120}$

$\underline{40}$

$\underline{80}$

Total Unit ekuivalen

$\underline{620}$

$\underline{540}$

$\underline{580}$

Rata-rata tertimbang untuk biaya per unit ekuivalen Departemen Pencampuran adalah sebagai berikut: (dalam ribuan)

Bahan Tenaga

Baku Kerja

Overhead

Biaya persediaan awal

$\mathrm{Rp}$

$\mathrm{Rp}$

$\mathrm{Rp}$ 


$$
1.892,00 \quad 400,00 \quad 796,00
$$

Biaya ditambahkan periode $\quad R$

berjalan

Total biaya

dipertanggungjawabkan

Dibagi dengan unit

ekuivalen

Biaya per unit ekuivalen
$13.608,00$

$\mathrm{Rp}$

$5.000,00$

$\mathrm{Rp}$

$5.400,00$

$15.500,00$

620

540

580

$\mathrm{Rp}$

25,00

$\mathrm{Rp}$

10,00

$\mathrm{Rp}$

15,00

Berdasarkan dari data-data yang tersajikan diatas, maka laporan biaya produksi bulan Juni untuk Departemen Pencampuran adalah sebagai berikut:

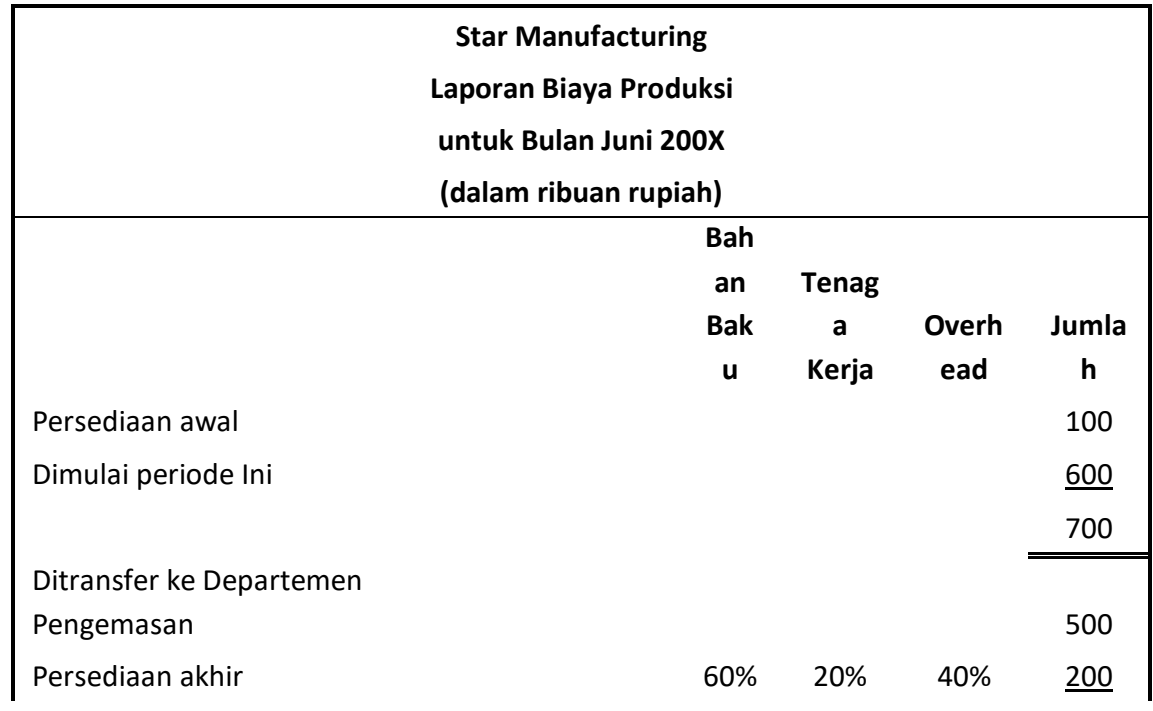




\section{Biaya dibebankan ke}

Departemen

Persediaan awal

Bahan baku

Tenaga kerja

Overhead pabrik

Total biaya persediaan

awal

$\begin{array}{lll} & \text { Unit } & \text { Biaya } \\ \text { Total } & \text { Ekuiva } & \text { Per } \\ \text { Biaya } & \text { len } & \text { unit }\end{array}$

1892

400

796

3088

Biaya ditambahkan selam periode

berjalan

Bahan baku

$13608 \quad 620$

Tenaga kerja

$5000 \quad 540$

Overhead pabrik

Total biaya ditambahkan

periode berjalan

$7904 \quad 580$

26512

Total biaya dibebankan ke

departemen

29600

50

\section{Biaya}

Dipertanggungjawabkan

$\begin{array}{lllll} & & \text { Unit } & & \\ \text { Uni } & \text { penyeles } & \text { vale } & \text { Per } & \text { Total } \\ \text { t } & \text { aian } & \text { n } & \text { Unit } & \text { Biaya }\end{array}$

Ditransfer ke Departemen

Pengemasan

500

100

500

50

25000

Barang dalam proses, persediaan akhir

Bahan baku

200

Tenaga kerja

200

60120

253000

$20 \quad 40$

$10 \quad 400$ 


$$
80
$$$$
15
$$

Jurnal untuk mencatat biaya yang ditransfer dari Departemen Pencampuran ke Departemen Pengemasan adalah sebagai berikut: (dalam ribuan)

Barang dalam Proses-Departemen Pengemasan Rp 25.000,00

Barang dalam Proses-Departemen

Pencampuran

$\operatorname{Rp} 25.000,00$

Setelah produk selesai diproses dalam Departemen Pencampuran, maka akan ditransfer ke Departemen Pengemasan dan Laporan Biaya Produksi untuk Departemen Pengemasan dapat dibuat. Jumlah unit yang ditransfer dari Departemen Pengawasan ke Barang Jadi adalah $100 \%$ selesai untuk semua elemen biaya(580 unit ekuivalen dari departemen sebelumnya yaitu bahan baku, tenaga kerja dan overhead pabrik). Hal ini mengindikasikan bahwa seluruh biaya yang ditransfer dari departemen sebelumnya merupakan unit yang sepenuhnya selesai dari departemen sebelumnya sehingga ditransfer ke departemen selanjutnya.

Persediaan Akhir Barang dalam Proses Departermen Pengemasan untuk bahan baku sebesar 100\% (100 unit ekuivalen bahan baku), biaya konversi selesai 70\% (100 unit x 70\% = 70 unit ekuivalen untuk masing-masing tenaga kerja dan overhead). Dengan hasil perhitungan sebagai berikut: 


\begin{tabular}{lcccc} 
& $\begin{array}{l}\text { Biaya Dari } \\
\text { Departemen } \\
\text { Sebelumnya }\end{array}$ & $\begin{array}{c}\text { Bahan } \\
\text { Baku }\end{array}$ & $\begin{array}{c}\text { Tenaga } \\
\text { Kerja }\end{array}$ & Overhead \\
\cline { 2 - 5 } $\begin{array}{l}\text { Unit ekuivalen ditransfer } \\
\text { keluar } \\
\begin{array}{l}\text { Unit ekuivalen dipersediaan } \\
\text { akhir }\end{array}\end{array}$ & $\underline{100}$ & $\underline{\underline{120}}$ & $\underline{40}$ & $\underline{80}$ \\
Total Unit ekuivalen & $\underline{680}$ & $\underline{620}$ & $\underline{540}$ & $\underline{580}$
\end{tabular}

Untuk biaya per unit ekuivalen dengan metode rata-rata tertimbang di Departemen Pengemasan adalah sebagai berikut: (dalam ribuan rupiah)

Biaya persediaan awal

Biaya ditambahkan periode

berjalan

Total biaya

dipertanggungjawabkan

Dibagi dengan unit ekuivalen

Biaya per unit ekuivalen
Biaya Dari

\begin{tabular}{cccc} 
Departemen & Bahan & Tenaga & \\
Sebelumnya & Baku & Kerja & Overhead \\
\hline
\end{tabular}

$\begin{array}{llll}8320 & 830 & 475 & 518\end{array}$

$25000 \quad 7296 \quad 9210 \quad 11052$

33320

8126

9685

11570

680

$680 \quad 650$

650

49

12

15

18

Biaya departemen sebelumnya sebesar Rp 49.000,00 per unit ekuivalen adalah lebih kecil apabila dibandingkan dengan biaya per unit yang ditransfer keluar oleh Departemen Pencampuran di bulan Juni sebesar $\mathrm{Rp} 50.000,00$. Hal ini terjadi dikarenakan Departemen Pengemasan menerima biaya per unit dari Departemen Pencampuran lebih besar dibandingkan dengan periode sebelumnya. Untuk biaya yang telah diterima di Departemen 
Pengemasan diperhitungkan dengan metode rata-rata tertimbang, sebagai berikut:

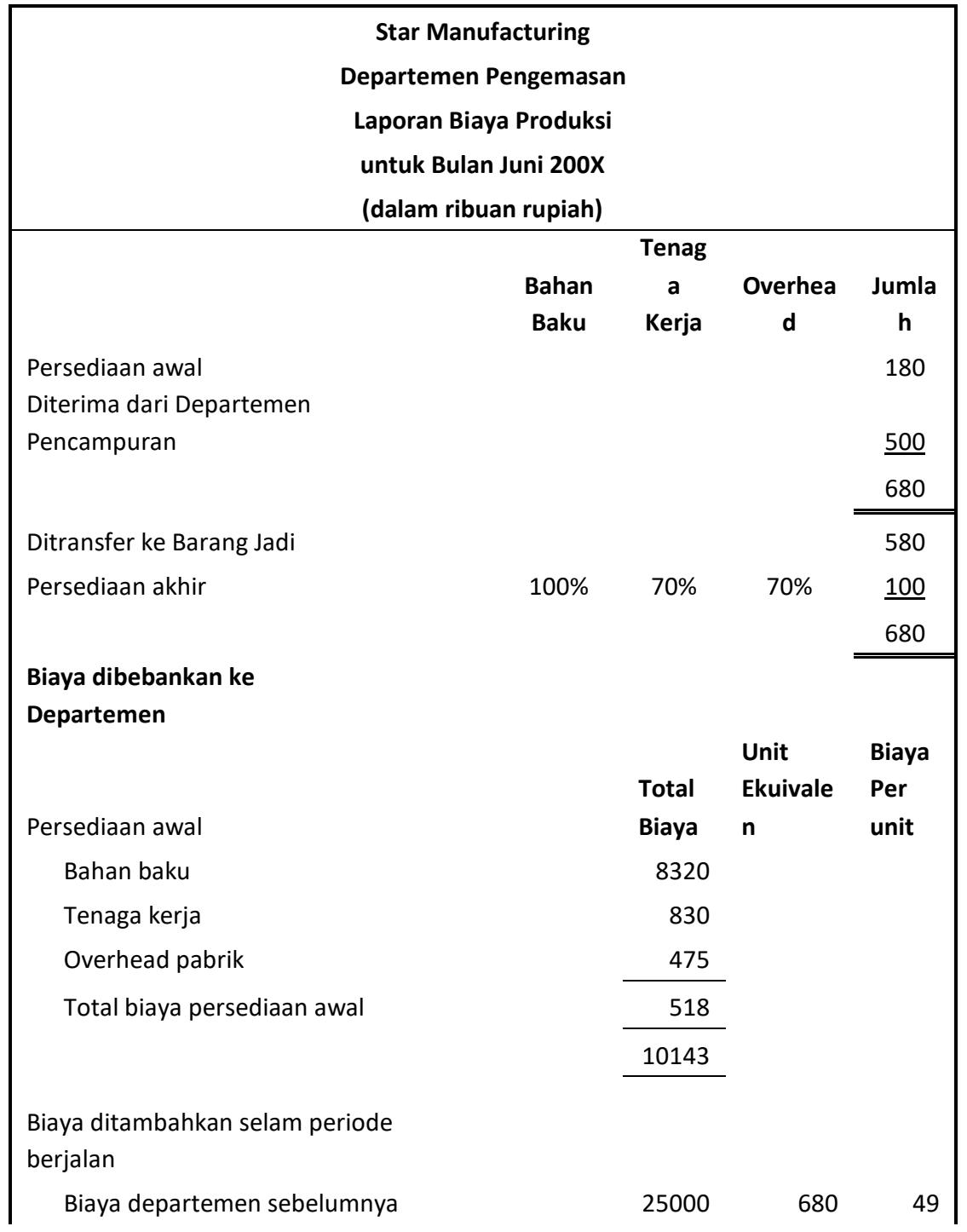


Bahan baku

Tenaga kerja

$7296 \quad 680$

Overhead pabrik

Total biaya

ditambahkan periode

berjalan

52558

Total biaya dibebankan ke

departemen

62701

Biaya

Dipertanggungjawabkan

$\begin{array}{lllll} & \% & & & \\ & \text { peny } & \text { Unit } & \text { Biaya } & \\ \text { Uni } & \text { elesa } & \text { ekuivale } & \text { Per } & \text { Total } \\ \text { t } & \text { ian } & \mathbf{n} & \text { Unit } & \text { Biaya }\end{array}$

Ditransfer ke Departemen

Pengemasan

580

100

580

94

54317

Barang dalam proses, persediaan akhir

Bi Dept Sebelumnya

100

100

100

49

4900

Bahan baku

100

100

100

12

1195

Tenaga kerja

100

70

15

1043

Overhead pabrik

100

70

70

18

1246

8384

Total biaya

dipertanggungjawabkan

62701

Dari data prhitungan diatas, maka ayat jurnal untuk mencatat biaya yang ditransfer dari Departemen Pengemasan ke Barang jadi sebagai berikut:

Persediaan Barang Jadi

Rp 54.317.000,00 
Terdapat juga metode FIFO (First In First Out) selain metode rata-rata tertimbang, akan tetapi metod FIFO jarang dipergunakan dengan petimbangan biaya bahan baku yang tidak berbeda dengan periode sebelumnya.

\section{Soal Diskusi}

1. Perhitungan biaya berdasarkan proses perlu dilakukan dalam perusahaan manufaktur, apakah tujuan dari perhitungan tersebut?

2. Bagaimana perbandingan perhitungan biaya berdasarkan proses dengan perhitungan biaya berdasarkan pesanan?

3. Apa fungsi laporan biaya produksi?

4. Tahapan apa yang harus dilakukan untuk membuat laporan biaya produksi?

\section{Soal Perhitungan}

Harum Company memproduksi pengharum ruangan yang diproduksi melalui dua departemen yaitu : Pencampuran dan Penyelesaian. Adapun data yang berhubungan dengan operasional bulan Desember 2015 adalah sebagai berikut :

Data Produksi : 
Pencampuran Penyelesaian

Unit awal dalam proses

1000

1400

Unit baru dalam proses

6000

Unit yg ditransfer dr Blending ke Finishing 6400

6400

Unit yg ditransfer ke gudang brg.jadi

7400

Unit akhir dalam proses:

- Pencampuran (60\% M; 20\% L; 25\% FOH) 600 -

- Penyelesaian (100\% M; 70\% L; 70\% FOH) - 400

Data Biaya :

PencampuranPenyelesaian

Biaya persediaan awal barang dlm proses:

Biaya dr departemen terdahulu

Rp 15.400

Material

Rp18.220

Rp 3.400

Labor

Rp 6.160

Rp 3.360

$\mathrm{FOH}$

Rp 4.035

Rp 3.860

Biaya tambahan selama periode berjalan :

Material

Labor

$\mathrm{FOH}$

$\begin{array}{ll}\text { Rp29.100 } & \text { Rp } 20.000 \\ R p \quad 6.880 & R p 12.000 \\ R p \quad 9.065 & R p 11.500\end{array}$

\section{Diminta :}

1. Buatlah laporan biaya produksi untuk setiap departemen di bulan Desember dengan menggunakan metode rata-rata tertimbang (Average Costing), serta ayat jurnal untuk 
mengakui barang dalam proses dalam laporan biaya produksi. 


\section{BAB 7}

\section{SISTEM PERHITUNGAN ALOKASI BIAYA PRODUK GABUNGAN}

\section{DAN PRODUK SAMPINGAN}

Perusahaan manufaktur sangat memperhatikan efisiensi biaya produksi yang dibebankan ke produk. Dalam proses produksi seringkali terdapat produk sampingan yang dihasilkan bersamaan dengan proses produksi produk utama yang akan memberikan hasil tambahan untuk perusahaan. Di lain pihak ada beberapa proses yang sama terhadap beberapa produk yang berbeda akan membebankan produk gabungan bagi setiap produk yang dihasilkan. Dan harus dilakukan alokasi atas biaya gabungan yang terbentuk.

\section{Pengertian Produk Sampingan dan Produk Gabungan}

Produk Sampingan atau dikenal dengan istilah by productmerupakan produk dengan nilai total relatif kecil dan dihasilkan secara simultan atau bersamaan dengan produk lain dengan total nilai lebih besar (merupakan produk utama atau main product). Produk utama diproduksi jauh lebih besar dibandingkan dengan produk sampingan. Untuk itu perusahaan jarang memiliki kendali atas produksi produk sampingan. Dengan perkembangan diperkenalkan metode yang cukup maju untuk mengendalikan nilai residu dan produk sampingan lainnya agar dapat teridentifikasi.

Sedangkan produk gabungan dikenal dengan istilah joint cost adalah produk yang dihasilkan secara simultan atau bersamaan dalam proses umum atau sama. Seluruh produk dihasilkan dalam proses yang sama, walaupun tidak harus dalam proporsi yang sama. 
Pada saat produk selesai diproses akan dipisahkan sesuai dengan unit-unitnya, atau dengan istilah titik pisah batas (split-off point).

\section{Karakteristik Produk Sampingan dan Produk Gabungan}

Produk sampingan muncul dari identifikasi residu hasil produksi produk utama. Bahkan dalam beberapa kasus produk sampingan merupakan sampah ataupun sisa produksi seperti contohnya serbuk gergaji. Dalam contoh lain adalah saat proses persiapan bahan baku yaitu pengupasan kulit dari biji coklat, biji kacang, pengupasan kulit apel, dan lain sebagainya. Produk sampingan dapat diklasifikasikan dalam dua kelompok yaitu (a) akan dijual pada bentuk asal tanpa merubah bentuk dan menambah nilai, (b) Dilakukan proses lebih lanjut agar produk dapat dijual dan memberikan nilai tambah.

Untuk produk gabungan kasus yang terjadi sebagai contoh pemotongan daging. Terdapat berbagai jenis potongan dengan satu total biaya. Untuk perhitungan biaya produk gabungan ditemukan pada insudtri yang harus memilah bahan baku sebelum diproses. Produsen menghadapi permasalahn ganda untuk mengalokasikan biaya gabungan: (a) biaya bahan baku berlaku untuk semua tingkat pemilahan, (b) biaya proses produksi selanjutnya akan menjadi simultan untuk semua jenis tingkatan mutu.

\section{Biaya Gabungan}

Biaya yang muncul dari proses produksi yang sama atas beberapa jenis produk disebut sebagai biaya gabungan. Apabila terdapat minimal dua produk yang mendapatkan perlakuan sama 
maka merupakan produk gabungan, biaya gabungan ini terjadi sebelum titik pisah batas.

Dalam total biaya produksi dari berbagai jenis produk yang melibatkan biaya gabungan, maupun biaya produksi individual terpisah. Biaya tersebut menjadi biaya produk terpisah (separable product cost) untuk biaya produk terpisah tidak memerlukan alokasi.

\section{Kendala Perhitungan Biaya Produk Sampingan dan Produk Gabungan}

Rumitnya perhitungan biaya produk sampingan dan produk gabungan, karena sesungguhnya biaya gabungan tidak dapat dibagi.

Seperti contohnya dalam satu mineral dapat mengandung bebapa macam mineral saat ditambang. Dalam kondisi mentah, maka mineral tersebut merupakan produk gabungan sampai dipisahkan dalam pemrosesan bijih mineral. Maka biaya yang muncul dalam proses menemukan, menambang dan memproses biji merupakan biaya produk gabungan karena merupakan biaya sebelum adanya titik pisah batas. Biaya produk gabungan akan diakumulasikan kemudian dibebankan ke masing-masing produk berdasarkan selisih antara harga jual dengan biaya untuk menyelesaikan dan menjual mineral yang diproduksi pada titik pisah batas. Perhitungan biaya produk gabungan dan produk sampingan untuk membebankan biaya ke produk asal dengan menggunakan peralatan, bahan baku, tenaga kerja dan biaya lainnya tidak dapat sebenar-benarnya ditentukan.Alokasi biaya gabungan mungkin harus menggunakan justifikasi harga jual. Akan tetapi validitas pemisahan biaya gabungan yang menentukan harga wajar dalam penntapan harga produk diatur oleh pemerintah. 


\section{Perhitungan Biaya Produk Sampingan}

Untuk melakukan perhitungan terhadap produk sampingan terdapat dua kateori yaitu (1) Pendapatan yang diperoleh dari hasil penjualan dikreditkan ke penjualan produk utama. Dalam laporan laba rugi ditampilkan sebagai berikut:
a. Pendapatan lain-lain
b. Tambahan Pendapatan Penjualan
c. Pengurang Harga Pokok Penjualan
d. Pengurang biaya produksi produk utama

Untuk kategori kedua dalam menghitung biaya produk sampingan sebagian biaya dari produk gabungan dialokasikan ke produk sampingan, sehingga untuk kategori ini produk sampingan mendapatkan perlakuan sama dengan produk gabungan. Metode perhitungan untuk kategori ini adalah metode biaya penggantian (replacement cost method) dan metode nilai pasar (market value method)

\section{Pengakuan Pendapatan Kotor}

Dengan metode pendapatan kotor (gross revenue method), biaya persediaan final dari produk utama dihitung terlalu tinggi karena menanggung biaya yang seharusnya dibebankan ke produk sampingan.

Metode a: Pendapatan Produk Sampingan sebagai Pendapatan Lain-lain.Dalam metode ini hasil penjualan produk sampingan akan 
dimasukkan dalam pendapatan lain-lain yang akan menambah laba sebelum pajak.

Metode b: Pendapatan Produk Sampingan sebagai Tambahan Pendapatan Penjualan. Dengan metode ini hasil penjualan dari produk sampingan akan menambah nilai dari penjualan produk utama. Nilai pertambahan laba sama dengan metode a.

Metode c: Pendapatan Produk Sampingan sebagai Pengurang Harga Pokok Penjualan. Dengan metode ini nilai harga pokok penjualan akan berkurang sebesar nilai pendapatan produk sampingan, akan tetapi laba sebelum pajak akan sama dengan metode-metode sebelumnya.

\section{Metode d: Pendapatan Produk Sampingan Mengurangi Biaya} Produksi. Untuk metode ini pendapatan produk sampingan akan mengurangi biaya produksi sebesar nilai pendapatan produk sampingan, harga pokok penjualan akan berkurang, namun laba sebelum pajak nilainya tetap sama dengan metode sebelumnya.

Metode Alokasi Biaya Produksi Bersama ke Produk Gabungan.

Biaya produk gabungan merupakan biaya yang terjadi terhadap beberapa jenis produk yang mendapatkan perlakuan yang sama sebelum titik pisah batas. Alokasi biaya gabungan kepada produk gabungan menggunakan beberapa metode:

Metode Harga Pasar 
Metode harga pasar banyak yang berpendapat bahwa harga pasar produk sampai batas tertentu adalah manifestasi dari seluruh biaya yang dikeluarkan hingga produk siap dijual. Sehingga terdapat anggapan bahwa jika harga suatu barang mahal dikarenakan biaya produksi yang dikeluarkan lebih tinggi.

Terdapat pendapat lain dalam mempergunakan harga pasar untuk mengalokasikan biaya gabungan yaitu metode netral yang artinya bahwa metode ini tidak mempengaruhi profitabilitas relatif dari produk gabungan. Keputusan yang dibuat berdasarkan pada analisis atas profitabilitas.

\section{Produk Gabungan yang Dapat Dijual Pada Titik Pisah Batas.}

Dalam metode harga pasar yang mengalokasikan biaya gabungan berdasarkan harga pasar relatif dari produk gabungan. Menggunakan total harga pasar untuk setiap produknya, yaitu jumlah unit yang diproduksikan dikalikan dengan harga jual per unit. Sebagai contoh terdapat produk gabungan $P, Q, R, S$ diproduksi dengan biaya gabungan $\mathrm{Rp} 120.000 .000,00$. Kuantitas yang diproduksi untuk masing-masing produk adalah $P 200$ unit, Q 150 unit, R 100 unit, S 150 unit. Dengan harga jual produk P Rp 100.000,00, Q Rp 150.000,00, R Rp 350.000,00 dan S Rp 500.000,00. Alokasi biaya gabungan diperhitungkan sebagai berikut: (nilai dalam ribuan rupiah)

\begin{tabular}{|l|l|l|l|l|l|}
\hline Produk & $\begin{array}{l}\text { Unit } \\
\text { Diproduksi }\end{array}$ & $\begin{array}{l}\text { Harga } \\
\text { Pasar per } \\
\text { Unit }\end{array}$ & $\begin{array}{l}\text { Total } \\
\text { Harga } \\
\text { Pasar }\end{array}$ & $\begin{array}{l}\text { Prosentase } \\
\text { nilai } \\
\text { produk }\end{array}$ & $\begin{array}{l}\text { Alokasi } \\
\text { Biaya } \\
\text { Gabungan }\end{array}$ \\
\hline
\end{tabular}




\begin{tabular}{|r|r|r|r|r|r|}
\hline & & & & $*$ & $*$ \\
\hline $\mathrm{P}$ & 200 & 100 & 20000 & $13,11 \%$ & 15.738 \\
\hline $\mathrm{Q}$ & 150 & 150 & 22500 & $14,75 \%$ & 17.705 \\
\hline $\mathrm{R}$ & 100 & 350 & 35000 & $22,95 \%$ & 27.541 \\
\hline $\mathrm{S}$ & 150 & 500 & 75000 & $49,18 \%$ & 59.016 \\
\hline & & & 152500 & $100 \%$ & 120000 \\
\hline
\end{tabular}

Catatan :

* $\quad \operatorname{Rp} 20.000 .000,00 / \operatorname{Rp~152.500.000,00~x~100\% ~=~} 13.11 \%$

** $\quad \mathrm{Rp} 20.000 .000,00 / \operatorname{Rp~152.500.000,00.~Rp~120.000.000~=~} \$ 3.750$

(13.11\%. Rp 120.000.000,00 = Rp 15.738.000,00) atau

(\$120000 / \$152.500.000) X 100\% = 79\% untuk masing-2 produk

Hasil yang sama juga akan diperoleh apabila total biaya produksi

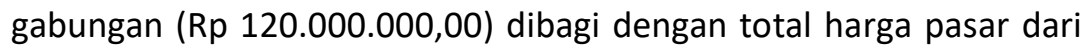
keempat produk. Angka yang dihasilkan sebesar 0.79 merupakan rasio biaya produk gabungan dari setiap produk terhadap harga pasarnya.

Dari metode harga pasar, setiap produk gabungan menghasilkan presentase laba kotor yang sama, dengan asumsi bahwa unit dijual tanpa ada proses lebih lanjut.

\section{Produk Gabungan yang Tidak Dapat Dijual pada Titik Pisah Batas}

Untuk produk yang tidak data dijual pada titik pisah batas, dikarenakan tidak memiliki harga pasar dan memerlukan proses lebih lanjut agar dapat dijual. Dengan adanya kasus seperti ini dasar alokasi yang dipergunakan untuk alokasi biaya gabungan adalah harga pasar hipotetis. Dengan perhitungan sebagai berikut: (memakai kasus pada metode sebelumnya) 


\begin{tabular}{|c|r|r|}
\hline Produk & \multicolumn{1}{|c|}{$\begin{array}{c}\text { Nilai pasar /unit } \\
\text { setelah proses }\end{array}$} & By.proses setelah titik pisah \\
\hline P & 150 & 4000 \\
\hline Q & 400 & 3000 \\
\hline R & 600 & 5500 \\
\hline S & & 10000 \\
\hline
\end{tabular}

Informasi diatas merupakan penambahan nilai harga pasar serta biaya yang harus dikeluarkan untuk proses lebih lanjut. Harga pasar hipotetis yang muncul merupakan perkiraan dengan adanya penambahan biaya pemasaran dan administrasi. Dengan perhitungan metode produk biaya yang tidak dapat dijual pada titik pisah batas sebagai berikut: (nominal dalam ribuan rupiah)

\begin{tabular}{|c|c|c|c|c|c|c|c|c|}
\hline (a) & $\begin{array}{l}\text { Nilai } \\
\text { pasa } \\
\text { r/uni } \\
t \\
\text { setel } \\
\text { ah } \\
\text { dipr } \\
\text { oses } \\
\text { (b) }\end{array}$ & $\begin{array}{l}\text { Unit } \\
\text { yang } \\
\text { dipro- } \\
\text { duksi }\end{array}$ & $\begin{array}{l}\text { Nilai } \\
\text { pasar } \\
\text { setelah } \\
\text { diproses } \\
\text { (d) }\end{array}$ & $\begin{array}{l}\text { By } \\
\text { proses } \\
\text { stl ttk } \\
\text { pemisa } \\
\text { h } \\
\text { (e) }\end{array}$ & $\begin{array}{l}\text { Nilai } \\
\text { pasar } \\
\text { hipotetis }\end{array}$ & $\begin{array}{l}\text { Pembagian } \\
\text { by prod } \\
\text { gabungan } \\
\text { (g) }\end{array}$ & $\begin{array}{l}\text { Total } \\
\text { by.pro- } \\
\text { duksi } \\
\text { (h) }\end{array}$ & $\begin{array}{l}\text { \% total } \\
\text { by.pro- } \\
\text { duksi } \\
\text { (i) }\end{array}$ \\
\hline$P$ & 150 & 200 & 30000 & 4000 & 34000 & 19200,00 & 23200,00 & 77,33 \\
\hline$Q$ & 200 & 150 & 30000 & 3000 & 33000 & 18635,29 & 21635,29 & 72,12 \\
\hline $\mathrm{R}$ & 400 & 100 & 40000 & 5500 & 45500 & 25694,12 & 31194,12 & 77,99 \\
\hline$S$ & 600 & 150 & 90000 & 10000 & 100000 & 56470,59 & 66470,59 & 73,86 \\
\hline $\begin{array}{l}\text { tot } \\
\text { al }\end{array}$ & & & 190000 & 22500 & 212500 & 120000 & 142500 & 75,00 \\
\hline
\end{tabular}


Jika ada produk tertentu yang dapat dijual pada titik pisah batas sementara produk lain tidak maka untuk kelompok pertama menggunakan perhitungan produk dijual pada titik pisah batas sementara yang lain dijual dengan proses lebih lanjut.

\section{Analisis Biaya Produksi Bersama untuk Pengambilan Keputusan Manajerial dan Analisis Profitabilitas}

Metode alokasi biaya gabungan mengindikasikan bahwa julah biaya yang akan dibebankan ke berbagai produk yang dihasilkam pada titik pisah batas akan sulit ditentukan untuk tujuan apapun. Selanjutnya penerimaan atas metode alokasi untuk membnebankan biaya gabungan belumdapat memecahkan masalah. Sehingga memerlukan gagasan yang lebih maju untuk dapat menyatakan bahwa penetuan biaya individual atas produk gabungan sampai pada titik pisah batas tidak diperlukan, karena akan lebih penting untuk menghitung margin laba secara keseluruhan. Akan tetapi informasi tentang biaya yang terjadi saat titik pisah batas dapat memberikan dasar kepada manajemen untuk mengambil keputusan apakah akan melakukan proses lebih lanjut atau produk dijual saat titik pisah batas.

Biaya gabungan dapat terjadi atas produk-produk yang sampai batas tertentu dapat saling mengganti. Dan terlebih lagi terdapat peningkatan output dari suatu produk gabungan akan memerlukan tambahan bahan baku dan sekaligus akan meningkatkan output dari produk gabungan lainnya. 
Dalam perencanaan laba, sebaiknya manajemen mempertimbangkan margin kontribusi dari seluruh produk gabungan setelah biaya dapat dipisahklan dikurangkan dari penjualan. Margin kontribusi ini memungkinkan manajemen untuk memprediksikan kontribusi masing-masing segmen atau lini produk bagi laba perusahaan. Margin ini bukanlah angka laba bersih produk. Margin tersebut hanya mengindikasikan profitabilitas relatif dalam perbandingan dengan produk lain. Hal ini disebabkan karena data laba bersih tidak dapat digunakan untuk memprediksikan hasil keputusan yang berbeda. Untuk alasan-alasan tersebut, usaha-usaha untuk mengalokasikan biaya pemasaran ke produk dan pelanggan dengan melakukan studi waktu atas aktivitas karyawan penjualan, maupun usaha-usaha untuk mengalokasikan biaya produk gabungan yang seringkali memberikan hasil yang tidak dapat diandalkan untuk menilai profitabilitas suatu segmen.

Sehingga biaya produksi gabungan muncul sebagai akibat dari pemrosesan secara simultan atau produksi berbagai produk yang dihasilkan dari proses yang sama. Untuk menghitung nilai persediaan biaya gabungan ini dapat saja dialokasikan produk sampingan yang nilainya relatif kecil. Sebaliknya alokasi tersebut harus dilakukan ke produk gabungan yang memiliki nilai relatif lebih besar dari nilai nominal. Untuk keperluan pelaporan keuangan, beberapa metode dapat digunakan untuk menghitung biaya produk sampingan dan produk gabungan. Dalam hukum pajak penghasilamn terdapat indikasi bahwa ada kecenderungan kepada metode harga pasar. Manajemen sebaiknya mengenali keterbatasan alokasi biaya gabungan pada saat melakukan analisis produk individual dan ketika mengambil keputusan yang berkaitan dengan produk gabungan.

\section{Soal Diskusi}


1. Apakah yang membedakan antara produk gabungan dan produk sampingan?

2. Jelaskan penyajian pendapatan dari penjualan produk sampingan dalam laporan laba rugi.

3. Jelaskan metode mengalokasikan biaya produksi gabungan kepada produk gabungan.

4. Kapan alokasi biaya gabungan kepada produk gabungan diperlukan?

\section{Soal Perhitungan}

1. Gress Company menghasilkan produk $A, B, C, D$ dari suatu proses gabungan. Berikut informasi tambahan dalam proses produksi : (dalam ribuan)

\begin{tabular}{|c|c|c|c|c|}
\hline \multirow[t]{2}{*}{ Produk } & \multirow{2}{*}{$\begin{array}{l}\text { Unit yang } \\
\text { Diproduksi }\end{array}$} & \multirow{2}{*}{$\begin{array}{l}\text { Nilai Pasar } \\
\text { pada Titik } \\
\text { Pemisah }\end{array}$} & \multicolumn{2}{|c|}{ Jika Diproses Lebih Lanjut } \\
\hline & & & $\begin{array}{l}\text { Biaya } \\
\text { Tambahan }\end{array}$ & Nilai Pasar \\
\hline A & 6.000 & Rp 80.000 & Rp 7.500 & Rp 90.000 \\
\hline B & 5.000 & 60.000 & 6.000 & 70.000 \\
\hline C & 4.000 & 40.000 & 4.000 & 50.000 \\
\hline D & 3.000 & 20.000 & 2.500 & 30.000 \\
\hline Total & 18.000 & Rp 200.000 & $\begin{array}{c}\mathrm{Rp} \\
20.000\end{array}$ & Rp 240.000 \\
\hline
\end{tabular}




\section{Diminta:}

Alokasikan biaya gabungan ke setiap produk dengan menganggap bahwa total biaya produksi gabungan sebesar Rp 160.000.000 dialokasikan dengan menggunakan metode nilai pasar. 


\section{BAB 8}

\section{BAHAN BAKU}

Dalam perusahaan manufaktur bahan baku merupakan hal penting untuk dilakukan perencanaan, perhitungan dan pengendaliannya agar sesuai dengan kebutuhan dan tujuan perusahaan. Manajemen persediaan yang efektif sangat pentig dilakukan untuk dapat menyediakan layanan bagi pelanggan, untuk dapat melakukan produksi secara efisien, dan untuk mengendalikan investasi persediaan. Manajemen bahan baku yang telah berhasil mengembangkan suatu sistem yang melibatkan peramalan penjualan, pembelian, penerimaan, penyimpanan, produksi, dan pengantaran. Dalam hal ini akan menitikberatkan pada lingkungan dimana just in time belum diterapkan secara penuh.

\section{Perolehan dan Penggunaan Bahan Baku}

Walaupun dalam proses produksi dan kebutuhna bahan baku amat bervariasi sesuai dengan ukuran dan jenis industri dari perusahaan, pembelian dan penggunaan bahan baku biasanya meliputi langkah-langkah sebagai berikut:

1. Untuk setiap produk atau variasi produk, akan ditentukan rute untuk setiap produk yang merupakan urutan operasi yang akan dilakukan dan sekaligus menetapkan daftar bahan baku yang diperlukan yang merupakan daftar kebutuhan untuk setiap langkah dalam operasi tersebut. 
2. Anggaran produksi menyediakan rencana utama, dari mana rincian mengenai kebutuhan bahan baku akan dikembangkan.

3. Bukti penerimaan pembelian menginformasikan agen pembelian mengenai jumlah dan jenis bahan baku yang dibutuhkan.

4. Pesanan pembelian merupakan kontrak atas jumlahyang harus dikirimkan.

5. Laporan penerimaan mengesahkan jumlah yang diterima dan mungkin juga melaporkan pemeriksaan dan pengujian mutu.

6. Bukti permintaan bahan baku memberikan wewenang bagi gudang untuk mengirimkan jenis dan jumlah tertentu dari bahan baku ke departemen tertentu dalam waktu tertentu.

7. Kartu catatan bahan baku mencatat seriap penerimaan dan pengeluaran dari setiap jenis bahan baku dan berguna sebagai catatan persediaan perpektual.

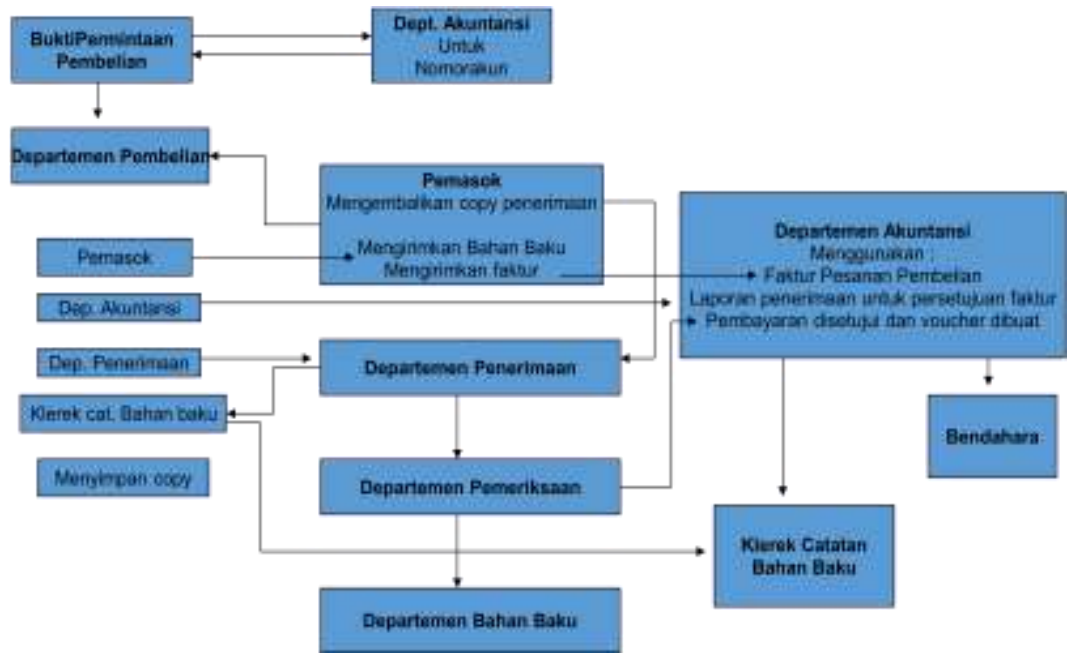


Gambar 9-1 Bagan alur pembelian, penerimaan, pencatatan dan pembayaran bahan baku

\section{Pembelian Bahan Baku}

Pembelian yang dilakukan oleh perusahaan besar biasanya terdapat departemen tersendiri yaitu departemen pembelian yang dikepalai oleh agen pembeli umum. Sedangkan dalam perusahaan yang lebih kecil para kepala departemen ataupun penyelia mempunyai wewenang untuk membeli bahan baku sesuai dengan kebutuhan. Prosedur pembelian bahan baku sebaiknya tertulis untuk untuk menetapkan tanggung jawab dan memberikan informasi mengenai penggunaan bahan baku.

Di beberapa kasus departemen pembelian memiliki tugas tambahan yaitu menyetujui pembayaran atas setiap faktur dari pemasok bahan baku. Dengan tugas tersebut perusahaan memiliki keuntungan lebih yaitu terdapat sentralisasi atas persetujuan faktur dan pembayaran oleh departemen yang menginisiasi pembelian tersebut dan memiliki informasi yang lengkap mengenai item dan jumlahh yang dipesan, harga, dan kondisi lainnya. Sebaliknya secara pengendalian akan berkurang karena individu yang sama membuat pesanan, menyetujui faktur atas pesanan dan kemudian menyetujui pembayarannya. Sehingga audit dan persetujuan atas faktur dibanyak perusahaan hal tersebuit merupakan fungsi dari departemen akuntansi. 
Untuk pembelian selain bahan baku, yaitu perlengkapan, jasa dan perbaikan. Langkah-langkah yang dipergunakan sama dengan langakah-langkah pembelian bahan baku.

\section{Formulir Pembelian}

Formulir utama yang diperlukan untuk bukti pembelian adalah bukti permintaan pembelian dan bukti pesanan pembelian.

\section{Bukti Permintaan Pembelian}

Bukti permintaan pembelian berawal dari (1) staf gudang yang mengetahui persediaan bahan baku telah mencapai batas untuk melakukan pemesanan kembali, (2) klerek catatan bahan baku ataupun penyelia lain dalam pabrik yang mempunyai wewenang untuk menginformasikan kepada staf pembelian agar melakukan pemesanan, (3) karyawan yang memerlukan bahan baku khusus, (4)program otomatisasi yang telah dirancang untuk memberikan pengingat kepada departemen pembelian tentang kapan diperlukan pengisian kembali persediaan. Setiap kopi bukti permintaan pembelian tetap dipegang oleh si pembuat dan aslinya dikirmkan ke departemen pembelian untuk dilaksanakan pembelian. Catatancatatan ini dapat berupa formulir kertas maupun elektronik. Untuk pembelian bahan baku standar, permintaa pembelian cukup mencantumkan jumlah unit yang dibutuhkan. Apabila permintaan pembelian terhadap bahan baku no standar maka dalam formulir permintaan bahan perlu dicantumkan nomor katalog, berat, merk, standar, julah serta harga yang disarankan. 


\section{Pesanan Pembelian}

Untuk pesanan pembelian yang telah mendapatkan validasi baik secara manual maupun secara elektronik oleh staf pembelian atau yang berwenang lainnya, aka memberikan wewenang kepada pemaso untuk mengirimkan barang sesuai dengan jumlah dan persyaratan yang telah ditentukan dan disepakati pada waktu dan tempat tertentu. Agar proses lebih mudah formulir pembelian memakai milik pemasok, akan tetapi yang sering terjadi adalah formulir pembelian menggunakan milik perusahaan pembeli, karena menyesuaikan dengan kebutuhan pembeli. Untuk kepentingan akuntansi formulir pesanan pembelian dapat disimpan dan diterbitkan untuk setiap pembelian bahan baku. Ketika komitmen pembelian dibuat melalui surat atau telepon ataupun melalui perwakilan penjualan, maka pesanan pembelian berfungsi sebagai konfirmasi.

\section{Electronic Data Interchange}

Electronic Data Interchange adalah pertukaran informasi transaksi antara komputer satu perusahaan dengan perusahaan lainnya, untuk mempermudah pemesanan dan mengurangi pemakaian dokumen kertas.

\section{Penerimaan}

Dalam Departemen Penerimaan bahan baku tahapannya adalah (1) membongkar bahan baku yang masuk, membandingkan jumlah yang diterima degan daftar perusahaan pengiriman, (3) mencocokkan bahan baku yang diterima dengan deskripsi pesanan pembelian, (4) membuat laporan penerimaan, (5) 
menginformasikan kepada departemen pembelian atas perbedaan yang ditemukan, (6) mengatur pemeriksaan apabila diperlukan, (7) memberitahukan kepada departemen pengantaran dan departemen pembelian mengenai kerusakan yang terjadi selama produk tersebut dalam perjalanan, (8) mengirimkan bahan baku yang diterima ke lokasi.

Laporan penerimaan menunjukkan nomor pesanan pembelian, nomor akun yang akan dibebankan, nama pemasok, rincian mengenai transportasi, serta jumlah dan jenis barang yang diterima. Laporan tersebut juga menyediakan ruang bagi departemen pemeriksaan untuk menuliskan persetujuannya atas kiriman tersebut maupun jumlah yang ditolak dan alasan penolakan.

Apabila bahan baku yang diterima tidak diterima, maka perlu dilakukan laporan penerimaan yang didistribusikan sebagai berikut: (1) departemen penerimaan menyimpan satu salinan dan mengirimkan salinan lainnya ke departemen pembelian sebagai pemberitahuan atas kedatangan bahan baku, (2) semua salinan lain dikirimkan ke departemen pemeriksaan dan kemudian didistribusikan setelah pemeriksaan. Saat pemeriksaan selesai satu salinan akan dikirimkan ke departemen akuntansi yang akan dicocokkan dengan pesanan pembelian dan faktur pemasok. Satu salinan lainnya dikirimkan ke departemen yang sesuai, dan salinan lainnya dikirimkan ke gudang bersamaan dengan bahan baku. Jika perusahaan telah memakai elektronik untuk mencatat laporan penerimaan, data akan dimasukkan secara elektronik menggunakan keyboard.

\section{Persetujuan Faktur dan Pemrosesan Data}


Untuk melakukan pengendalian bahan baku diperlukan persetujuan faktur untuk memverifikasi barang yang telah diterima sesuai dengan pesanan dan pembayaran yang dilakukan. Perusahaan memverifikasi dimulai saat bahan baku di terima dan menerima faktur di departemen penerimaan. Saat laporan penerimaan dan pemeriksaan diterima laporan penerimaan pesanan pembelian, dan faktur yang diterima akan dibandingkan jenis bahan baku, jumlah, harga, diskon, persyaratan kredit, instruksi pengiriman dan syarat lainnya.

\section{Biaya Perolehan Bahan Baku}

Biaya untuk memperoleh bahan baku yang jelas terlihat adalah harga barang yang tercantum dan beban transportasi. Sedangkan biaya yang tiak terlalu jelas adalah biaya akuisisi yaitu biaya yang dikeluarkan untuk melakukan fungsi pembelian, penerimaan, pembongkaran, pemeriksaan, asuransi, penyimpanan, dan akuntansi. Keterbatasan yang mempengaruhi perlakuan biayabiaya tersebut karena menyesuaikan setiap faktur dengan semua biaya akuisisi yang terlibat memerlukan usaha yang biayanya jauh lebih besar dibandingkan manfaat yang diperoleh, sehingga dengan semakin akuratnya pengukuran biaya. Oleh karena itu harga perolehan dicatat sesuai dengan harga yang tercantum dalam faktur pemasok, sedangkan biaya akuisisi dimasukkan dalam overhead pabrik.

Diskon Pembelian. Dalam penerimaan diskon perdagangan dan diskon pembelian dalam jumlah besar tidak dicatat dalam pencatatan apapun. Akan tetapi penerimaan diskon perdagangan dan diskon pembelian diperlakukan sebagai pengurang harga. 
Dimana harga yang dibayar kepada pemasok adalah harga setelah diskon.

Beban Angkut Pembelian. Beban angkut pembelian merupakan biaya bahan baku, akan tetapi dapat muncul beberapa kesulitan karena perbedaan syarat pengiriman. Jika unit yang dibeli dalam jumlah sedikit dan memiliki biaya per unit yang besar, maka jumlah beban angkut pembelian untuk setiap item mungkin dapat ditentukan dari tarif yang diberikan oleh perusahaan angkutan.

Jika beban angkut pembelian dimasukkan dalam debit ke akun Bahan Baku di buku besar, maka beban angkut pembelian akan dapat ditambahkan secara proporsional ke dalam setiap catatan pembantu bahan baku dari setiap item. Pembebanan dilakukan dengan cara mengalokasikan beban angkut pembelian berdasarkan biaya bahan baku.

Alternatif yang lebih sederhana adalah dengan membebankan semua beban angkut pembelian ke dalam akun Beban Angkut Pembelian dan mencatat hanya harga faktur sebagai biaya bahan baku, dan pada saat bahan baku dikeluarkan untuk dimasukkan dalammproduksi akan dikenakan tarif beban angkut pembelian tertentu sehingga nilainya lebih besar daripada biaya per unit yang tercantum dalam kartu catatan pembantu bahan baku.

Jumlah yang ditambahkan ini akan didebit dalam akun Barang dalam Proses (untuk bahan baku langsung) atau akun Pengendali Overhead Pabrik (untuk bahan baku tidak langsung), dan dikreditkan ke Beban Angkut Pembelian. Saldo di Beban Angkut Pembelian di akhir periode akan ditutup ke Harga Pokok Penjualan. 
Selanjutnya pendekatan terakhir adalah memasukkan semua beban angkut pembelian di periode tersebut dalam menghitung tarif overhead pabrik untuk periode itu. Dengan demikian, Beban Angkut Pembelian menjadi akun buku pembantu dalam Pengendali Overhead Pabrik. Sedangkan bahan baku ataupun perlengkapan yang digunakan oleh departemen pemasaran dan administrasi, beban angkut pembelian dibebankan ke Beban Pemasaran atau ke Beban Administrasi.

Biaya Akuisisi yang Dibebankan. Apabila bahan baku akan memasukkan biaya akuisisi, maka suatu tarif pembebanan tertentu dapat dikenakan ke setiap faktur dan setiap item, daripada membebankan biaya ke overhead pabrik. Untuk biaya akuisisi ini dapat menggunakan tarif tunggal maupun tarif yang terpisah untuk masing-masing kelas biaya sebagai berikut:

- Estimasi biaya departemen pembelian untuk periode anggaran Estimasi jumlah pesanan pembelian atau estimasi nilai pembelian

= Tarif per pesanan pembelian atau tarif per dolar pembelian

- Estimasi biaya departemen penerimaan untuk periode anggaran Estimasi jumlah item yang akan diterima selama periode tersebut

$=$ Tarif per item

- Estimasi departemen bahan baku untuk periode anggaran

Estimasi jumlah item, luas tempat, nilai dolar, dan seterusnya 
= Tarif per item, per kaki kubik, nilai dolar, dan seterusnya

- Estimasi biayadepartemen akuntansi yang dapat dibebankan untuk periode anggaran

Estimasi jumlah transaksi

$=$ Tarif per transaksi

Setiap departemen yang terlibat, aka biaya aktual yang terjadi didebit ke akun beban yang bersangkutan. Pada akhir periode, dimana selisih antar biaya yang terjadi dengan jumlah yang dibebankan akan mencerminkan biaya yang dibebankan terlalu rendah atau terlalu tinggi.Selisih terlau rendah ataupun terlalu tinggi tersebut akan ditutup pada Harga Pokok Penjualan maupun dibagi rata antara Harga Pokok penjualan dengan Persediaan Akhir.

\section{Penyimpanan dan Penggunaan Bahan Baku}

Bahan baku dan satu salinan laporan penerimaan bahan baku dikirimkan ke gudang, atau bagian penerimaan dan departemen pemeriksaan. Petugas gudang bertanggungjawab atas keamanan bahan baku, penempatan, ataupun lokasi hingga bahan baku dibutuhkan, serta memastikan bahwa semua bahan baku yang dikeluarkan dari gudang sesuai dengan bukti permintaan bahan baku yang bersangkutan.

\section{Buku Pembantu Bahan Baku}


Dalam sistem persediaan perpektual akan memasukkan setiap adanya penambahan ataupun pengurangan persediaan ke dalam buku pembantu bahan baku agar catatan tersebut selalu terkini. Pencatatan buku pembantu bahan baku dapat berupa kertas maupun secara eletronik, dan akan dikendalikan oleh buku besar bahan baku. Buku pembantu untuk akun Bahan Baku sama seperti buku pembantu pada umumnya yaitu memakai kolom debit, kredit dan saldo. Akan tetapi ada penambahan judul diterima, dikeluarkan dan Persediaan. Selain itu dapat ditambahkan nomor laporan penerimaan bahan baku serta nomor bukti permintaan bahan baku.

Kemudian saat faktur telah mendapatkan persetujuan dari karyawan yang memiliki wewenang, akan dikirimkan ke bagian bahan baku untuk dicatat dan dijurnal di baguian diterima dan Persediaan dari buku pembantu. Apablia terdapat kondisi bahan yang tidak memuaskan baik dari pengiriman terakhir maupun pengeiriman sebelumnya dapat dikembalikan kepada pemasok. Dan nilai pengembalian tersebut dicatat dengan tanda kurung sebagai penanda untuk mengurangi saldo yang ada.

Pada saat petugas gudang mengeluarkan bahan baku, untuk dicatat tanggal, nomor bukti permintaan, nomor lot, jumlah dan biaya dari bahan baku yang dikeluarkan di bagian Dikeluarkan.

Alternatif lain dari sistem persediaan perpektual adalah sistem periodik, dimana nilai pembelian akan ditambahkan ke persediaan awal. Pada saat akhir periode untuk menghitung nilai bahan baku maka persediaan akhir akan diperhitungkan secara fisik dan biayanya akan dikurangkan dari jumlah tersebut, kemudian selisihnya akan dianggap sebagai biaya bahan baku yang dikeluarkan. Walaupun menggunakan sistem perpektual tetap membutuhkan perhitunga fisik secara periodik untuk menemukan 
ketidak sesuaian saldo bahan baku antara saldo catatan harian bahan baku dengan saldo aktual bahan baku. Ketidak sesuaian ini dapat muncul akibat kesalahan dalam mentransfer data faktur ke dalam buku pembantu, terjadi dari beberapa sebab yaitu kesalahan menghitung biaya dari bukti penerimaan, adanya kerusakan maupun pencurian. Sehingga secara periodik walaupun menggunakan metode perpektual tetap harus menghitung persediaan secara fisik.

Ayat jurnal untuk mencatat penurunan bahan baku adalah sebagai berikut:

Pengendali Overhead pabrik $\operatorname{xxxx}$

Bahan Baku

$x x x$

\section{Metode Kuantitatif}

Persediaan mempunyai fungsi pengaman atas kendali diantara kebutuhkan produksi atas konsumsi barang. Persediaan ada dalam berbagai bentuk yaitu bahan baku, barang dalam proses, persediaan barang jadi, produk dalam perjalanan, dalam titik distribusi gudang dan gerai ritel. Dalam setiap tahan harus terdapat justifikasi ekonomis yang baik untuk persediaan, karena setiap unit tambahan yang disimpan akan menimnulkan biaya tambahan.

\section{Merencanakan Kebutuhan Bahan Baku}

Terdapat dua faktor mendasar dalam perencanaan bahan baku, yaitu jumlah dan waktu pembelian. Dalam menentukan jumlah bahan baku yang akan dibeli serta kapan waktu yang paling tepat akan mempengaruhi jenis biaya yang saling berlawanan, yaitu biaya 
penyimpanan persediaan dan biaya karena tidak menyimpan persediaan dengan cukup.

\section{Kuantitas Pemesanan Ekonomis}

Kuantitas pemesanan ekonomis (economic order quantity EOQ) merupakan jumlah persediaan yang dipesan pada suatu waktu yang meminimalkan biaya persediaan tahunan. Apabila suatu perusahaan tidak terlalu sering membeli bahan baku dan melakukan pembelian tersebut dalam jumlah besar,biaya penyimpanan persediaan jadi lebih tinggi karena adanya investasi cukup besar untuk persediaan. Namun apabila investasi dalam persediaan lebih kecil, dengan biaya pemesanan yang cukup tinggi.

Biaya penyimpanan bahan baku seringkali dinyatakan sebagai bagian dari investasi rata-rata dalam persediaan. Akan sulit saat menentukan biaya yang diakibatkan karena tidak menyimpan persediaan dalam jumlah yang mencukupi . Akan tetapi jugha harus mempertimbangkan dalam melakukan penentuan jumlah pesanan dan titik pemesanan. Biaya pemesanan mencakup biaya untuk membuat bukti permintaan pembelian, pesanan pembelian, danlaporan penerimaan, menangani pengiriman, komunikasi dengan pemasok dan akuntansi atas pengantaran dan pembayaran. Biaya lain yang diakibatkan oleh persediaan yang tidak mencukupi adalah kesempatan yang hilang untuk melakukan penghematan dalam beban angkut pembelian dan pemanfaatan diskon pembelian.

Walaupun hanya biaya variabel yang relevan untuk menghitung EOQ dan titik pemesanan merupakan hal penting untuk mengurangi biaya tetap dan biaya variabel. Biaya tetap adalah biaya tempat penyimpanan (gudang), dapat dikurangi dengan pendekatan just in time. Untuk memperhitungkan diferensial atas persediaan, 
menggunakan rumus EOQ didalam rumus ini memerlukan data jumlah barang yang dibutuhkan, harga per unit, persentase biaya penyimpanan persediaan dan biaya per pesanan, sebagai berikut

$$
E O Q=\sqrt{2} \underline{2 \times R U} \times C O
$$

$\mathrm{CU} \times \mathrm{CC}$

Atau

Kuantitas Pemesanan Ekonomis :

$=\sqrt{2} \underline{x}$ jumlah yang diperlukan per tahun kali biaya per pesanan

Biaya per unit bahan baku x persentase biaya penyimpanan

\section{Menentukan Waktu Pemesanan}

Didalam pembahasan rumus EOQ kuantitas menjadi masalah dalam perencanaan persediaan, tetapi perlu dipertanyakan kapan pesanan sebaiknya dilakukan. Hal ini dipengaruhi oleh tiga faktor: (1) lamanya waktu pengiriman; (2) tingkat kebutuhan persediaan, (3) jumlah persediaan pengaman.

Untuk menentukan titik pemesanan akan relatif lebih sederhana jika mempunyai prediksi yang tepat untuk tingkat penggunaan serta waktu tunggu, yaitu jeda ataupun interval waktu 
diantara pemesanan dengan waktu penerimaan.Jika tindakan yang diambil pada saat kehabisan persediaan yang terjadi adalah dengan menghentikan proses produksi dari pesanan yang mengalami kekurangan bahan baku dan memulai proses produksi pesanan baru, oleh karenanya biaya kekurangan persediaan bahan baku sama dengan biaya persediaan bahan baku.

Rumus untuk menentukan titik pemesanan adalah sebagai berikut:

$$
I+Q D=L T Q+S S Q
$$

Dimana:

I = Saldo persediaan yang tersedia.

QD = Jumlah yang akan masuk, dari pesanan yang sebelumnya sudah dilakukan, transfer bahan baku dan retur dari gudang.

LTQ = Jumlah yang akan digunakan selama waktu tunggu, yang sama dengan waktu tunggu normal dalam bulan, minggu, atau hari dikalikan dengan penggunaan normal selama sebulan, seminggu atau sehari.

SSQ = Jumlah persediaan pengaman.

Untuk penentuan titik pemesanan ini didasarkan pada penggunaan selama waktu yang diperlukan untuk pembuatan permintaan pembelian, pemesanan, dan penerimaan bahan baku, plus cadangan untuk pengaman kehabisan persediaan. Titik pemesanan (order print) akan dicapai bila jumlah persediaan yang 
akan diterima sama dengan jumlah persediaan yang akan digunakan selama waktu tunggu dan jumlah persediaan pengaman.

\section{Pengendalian Bahan Baku}

Pengendalian bahan baku dilakukan melalui pengaturan fungsional, pembebanan tanggung jawab dan bukti-bukti yang terdokumentasi. Terdapat dua tingkat pengendalian persediaan yaitu pengendalian unit dan pengendalian uang. Manajer pembelian dan manajer produksi bertanggung jawab atas pengendalian unit karena bertugas untuk melakukan permintaan atas unit dan bukannya uang. Sedangkan manajemen eksekutif yang berperan dalam pengendalian ketersediaan finansial. Eksekutif merencanakan tingkat pengembalian yang sesuai atas modal yang digunakan, yaitu sejumlah nilai uang yang diinvestasikan dalam persediaan harus digunakan secara efeisien dan efektif.

Tujuan dasar dari pengendalian bahan baku adalah untuk mengetahui kemampuan melakukan pemesanan tepat waktu, tepat jumlah, tepat harga dan tepat kualitas. Dan pengendalian yang efektif sebaiknya:

1. Tersedia pasokan bahan baku yang diperlukan untuk operasi yang efisien dan bebas gangguan.

2. Penyediaan yang cukup untuk persediaan di dalam periode di mana pasokan cukup kecil dan mengantisipasi perubahan harga.

3. Penyimpanan bahan baku dengan waktu penangan dan biaya minimum serta melindungi bahan baku dari kehilangan akibat bencana alam, pencurian, bahkan kerusakan penangan. 
4. Meminimakan item-item yang tidak aktif, berlebih, usang dengan melakukan pelaporan perubahan produk yang mempengaruhi bahan baku.

5. Memberikan kepastian persediaan yang cukup untuk pengiriman segera ke pelanggan.

6. Menjaga agar jumlah modal yang diinvestasikan dalam persediaan berada di tingkat yang konsisten dengan kebutuhan opersi dan rencana manajemen.

\section{Soal Diskusi}

1. Dokumen apa saja yang sering digunakan untuk pembelian dan penggunaan bahan baku?

2. Kriteria apa saja yang dibutuhkan untuk menentukan biaya yang dapat dibukukan sebagai biaya persediaan?

3. Untuk melakukan perancangan sistem pengendalian membutuhkan tiga pertanyaan kunci, apa sajakah pertanyaan tersebut?

4. Apakah manajemen eksekutif lebih memperhatikan pengendalian unit atau pengendalian keuangan?

\section{Soal Perhitungan}

1. Pada tanggal 1 Juni perusahaan Damai ingin menentukan jumlah unit Bahan Baku $\mathrm{M}$ yang sebaiknya dipoesan untuk pengiriman bulan Agustus. Jadwal produksi menunjukkan kebutuhan 4200 unit bahan baku M untuk operasi bulan Juni, 4400 unit bulan Juli, dan 4700 untuk bulan Agustus. Pada tanggal 1 Juni tercatat persediaan sebesar 4400 unit tersedia, sebanyak 3600 sudah dipesan untuk pengiriman 
bulan Juli, serta 4500 unit sudah dipesan untuk pengiriman bulan agustus. Persediaan yang diperlukan untuk bulan Oktober adalah 3600 . Hitunglah jumlah yang akan dipesan di bulan September. 


\section{BAB 9}

\section{BIAYA TENAGA KERJA}

Dalam produksi memerlukan tenaga kerja untuk memproduksi produk dari bahan baku hingga menjadi barang jadi. Biaya yang muncul dari proses ini adalah biaya tenaga kerja. Biaya tenaga kerja merupakan kontribusi manusia dalam produksi. Dalam beberapa perusahaan biaya tenaga kerja ini merupakan biaya penting yang membutuhkan pengukuran, pengendalian, dan analisis yang sistematis. Biaya tenaga kerja terdiri atas gaji pokok dan tunjangan. Gaji pokok merupakan tarif dasar yang telah ditentukan disesuaikan dengan peraturan pemerintah dan dikelompokkan pada jenis operasi. Sedangkan Tunjangan merupakan elemen dari biaya tenaga kerja. Tunjangan disni termasuk didalamnya adalah tunjangan hari raya, tunjangan lembur, tunjangan cuti, premi asuransi. Gaji pokok dan tunjangan hanya merupakan salah satu elemen dalam hubungan dengan karyawan.

\section{Produktivitas dan Biaya Tenaga Kerja}

Produktivitas tenaga kerja (labor productivity) merupakan suatu ukuran kinerja produksi yang menggunakan pengeluaran atas usaha manusia sebagai tolok ukurnya.Produktivitas tenaga kerja mengukur kinerja seseorang dengan standar jumlah barang dan jasa yang dapat diproduksi oleh seorang pekerja dalam waktu tertentu. Dalam pengertian yang elbih luas, produktivitas dapat digambarkan sebagai efisiensi dengan sumber daya yang dikonversikan menjadi komoditas barang dan atau jasa. Produktivitas yang lebih tinggi yang 
dapat dicapai dengan membuat proses produksi lebih efisien melalui eliminasi aktivitas yang tidak bernilai tambah, dengan melakukan perbaikan, otomatisasi, dan lain sebagainya. Perubahan dalam pemanfaat tenaga kerja memerlukan perubahan untuk metode kompensasi serta diikuti dengan perubahan dalam akuntansi biaya tenaga kerja.

\section{Perencanaan Produktivitas}

Untuk perencanaan produktivitas yang bertanggungjawab atas penerapan rencana tersebut adalah manajer. Dan sebaiknya selalu konsisten dengan rencana -rencana yang ada, seperti anggaran operasi dan rencana untuk investasi seperti modal, riset, teknologi, pengembangan karyawan. Untuk merencanakan produksi memerlukan pertanyaan-pertanyaan sebagai berikut:

a. Bagaimana suatu perusahaan dapat mendefinisikan tingkat produktivitas dan hidup kerja yang bermutu?

b. Untuk perbaikan produktivitas prioritas mana yang didahulukan dan siapa yang harus bertanggung jawab atas perbaikan tersebut?

c. Bagaimana komitmen manajemen ekskutif dalam dikomunikasikan?

d. Seberapa jauh kepantasan karyawan terlibat dalam perencanaan dan penerapan?

e. Bagaimana kemajuan diukur?

\section{Pengukuran produktivitas}

Tujuan dilakukannya pengukuran produktivitas adalah untuk memberikan indeks yang padat dan akurat untuk membandingkan hasil aktual dengan suatu target atau kinerja standar.Pengukuran 
produktivitas harus mengakui kontribusi individual atas faktor faktor seperti karyawan, pabrik dan peralatan, produk dan jassa yang digunakan, modal yang diinvestasikan, serta pelayanan, pemerintah yang digunakan

\section{Rasio efisiensi produktivitas (productivity-efficiency ratio)} mengukur output dari suatu individu relatif terhadap standar kinerja. Rasio ini dapat digunakan untuk mengukur pancapaian operasional relative untuk mesin, operasi, departemen, ataupun organisasi secara keseluruhan.

\section{Dampak Ekonomi dari Penerapan Produktivitas}

Jika terjadi peningkatan produktivitas, maka tingkat laba bisnis serta pendapatan riil pekerja juga akan mengalami peningkatan. Selanjutnya dengan adanya peningkatan produktivitas memberikan peluang bagi masyarakat untuk memperoleh output lebih banyak dan lebih baik dari sumber daya yang telah tersedia. Dalam beberapa tahun terakhir, secara umum produktivitas perusahaan semakinb meningkat sehingga menyebabkan lebih banyak lagi barang dan jasa yang tersedia. Akan tetap terkadang keuntungan produktivitas menurun. Dimana keterlambatan menyebabkan peningkatan biaya. Jika peningkatan output tidak dapat mengimbangi kecepatan peningkatan biaya maka biaya per unit dan juga harga jual akan meningkat. Namun jika perusahaan ingin mempertahankan harga agar tidak mengalami kenaikan, maka tingkat upah harus dapat mencerminkan pengurangan biaya per unit yang disebabkan peningkatan produktivitas. 


\section{Peningkatan Produktivitas untuk Manajemen Sumber Daya Manusia yang lebih Berkembang}

Untuk pengembangan sumber daya manusia yang lebih baik, maka manajemen menawarkan prospek peningkatan produktivitas dan kualityas produk hasil dengan cara memberdayakan pekerja untuk berpartisipasi secara langsung dalam manajemen atas pekerjaan mereka. Yang dibutuhkan manajemen adalah perspektif yang kontinyu dan bersifat jangka panjang dan bukannya perspektif yang sporadis dan jangka pendek. 4 asumsi dasar yang merupakan karakteristik dari manajemen sumber daya manusia yang baik:

a. Orang yang melakukan pekerjaan tersebut adalah orang yang paling memiliki kualifikasi untuk memperbaikinya.

b. Pengambilan keputusan sebaiknya terjadi di tingkat paling bawah yang memungkinkan.

c. Partisipasi pekerja meningkatkan kepuasan kerja dan komitmen atas tujuan perusahaan.

d. Ada sejumlah besar ide yang dimiliki oleh pekerja yang menunggu untuk disentuh.

\section{Rencana Pemberian Insentif}

Pekerja memberikan kompensasi yang didasarkan pada kontrak tenaga kerja hasil negosiasi, produktivitas, pembagian laba, rencan pemberian insentif dan upah per jam. Berbeda dengan pembayaran per jam,per minggu, per bulan, maka rencana pemberian insentif adalah memberikan penghargaan bagi pekerja secara proporsional terhadap peningkatan output yang berkualitas tinggi. 
Tujuan dari pemberian insenti ini adalah untuk merangsang pekerja agar memproduksi lebih banyak, sehingga mereka memperoleh banyak upah, tetapi pada saat yang bersamaan tambahan output tersebut mengurangi biaya per unit.

Untuk mengubah dasar pemberian imbalan dari jam kerja yang dijalani menjadi pekerjaan yang diselesaikan. Sehingga dengan memproduksi lebih banyak dalam suatu waktu tertentu akan menghasilkan upah yang lebih tinggi. Perusahaan berusaha meningkatkan produktivitas karyawan di setiap tingakatn, lini. Dengan rencana pemberian insentif akan mendorong terciptanya lingkungan kerja dimana setiap orang harus mempunyai standar kinerja. Sebaliknya akan membahayakan bagi perusahaan dimana dalam jangka panjang gaji pokok dan insentif akan kehilangan identitasnya disaat karyawan mulai memandang insentif sebagai bagian dari gaji pokok. Oleh karena itu perusahaan harus menetapkan standar dengan jelas dan mengkomunikasikan kepada pekerja untuk mewujudkan tujuan rencana pemberian insentif yang dapat menghasilkan dampak sesuai dengan yang diinginkan.

\section{Jenis Rencana Pemberian Insentif}

Secara umum upah berdasarkan waktu dan upah berdasarkan output tidak dapat dipisahkan dengan jelas. Rencana pemberian insentif pada umumnya memperhitungkan tarif upah berdasarkan berbagai macam kombinasi antara output dan waktu. Untuk mempermudah perencanaan pemberian insentif, dibagi dalam beberapa jenis yaitu: 
Rencana Unit Kerja Langsung rencana yang paling sederhana yaitu dengan membayar upah di atas tarif dasar untuk produksi diatas standar.

Rencana Bonus Seratus Persen merupakan suatu variasi dari unit kerja langsung, dimana perbedaan terdapat dalam hal di mana standar tidak dinyatakan dalam uang, tetapi dalam waktu per unit output.

Rencana Bonus Kelompok merupakan rencana yang didesain untuk pembayaran insentif individual memicu produksi dengan tarif diatas standar. Setiap pekerja dalam kelompok menerima tarif per jam untuk produksi sampai sesuai jumlah output standar.

Rencana Insentif Organisasi Rencana insentif organisasi atau rencana pembagian keuntungan organisasi adalah gaya manajemen yang berpusat pada karyawan yang menekankan pada keterlibatan dan partisipasi dari seluruh karyawan. Fitur utama rencana ini adalah semua individu memiliki kapasitas untuk memberikan kontribusi yang berharga bagi suatu organisasi.

\section{Standar Waktu Teori Kurva Belajar}

Dalam hal perencanaan pemberian insentif dengan berdasarkan standar waktu tetap tidak selalu memberikan motivasi kepada pekerja secara efektif. Sehingga muncul teori kurva belajar yang memakai waktu sebagai standarnya. Teori kurva belajar menyatakan bahwa setiap kali kuantitas output kumulatif menjadi dua kali lipat, maka rata - rata waktu kumulatif per unit berkurang sebesar persentase tertentu. 
Berdasarkan kurva belajar yang telah diobservasi, standar waktu yang digunakan untuk menentukan besarnya insentif seorang pekerja dapat berubah terhadap standar waktu variabel dan bukannya standar waktu tetap.

\section{Akuntansi untuk Biaya Tenaga Kerja dan Pengendalian}

Dalam akuntansi tenaga kerja mencakup beberapa hala sebagai berikut:

1. Sejarah kerja dari setiap pekerja, seperti tanggal dipekerjakan, tingkat upah, penugasan awal, promosi, kenaikan gaji, dan waktu cuti untuk liburan atau karena sakit.

2. Informasi yang diperlukan untuk memenuhi kontrak serikat kerja, hukum jaminan sosial, peraturan upah dan jam, pajak penghasilan ditahan, dan persyaratan pemerintah federal, negara bagian, atau lokal lainnya.

3. Waktu kerja dan biaya standar.

4. Jam kerja setiap karyawan, tingkat upah, dan total pendapatan untuk setiap periode penggajian.

5. Perhitungan potongan dari upah kotor untuk setiap karyawan.

6. Output atau pencapaian dari setiap karyawan.

7. Jumlah biaya dan jam dari tenaga kerja langsung maupun tidak langsung yang akan dibebankan ke setiap pesanan, lot, proses atau departemen untuk setiap periode.

8. Total biaya tenaga kerja disetiap departemen untuk setiap periode. 
9. Data kumulatif atas potongan pendapatan dan gaji untuk setiap karyawan.

\section{Departemen Penggajian}

Dengan memperhitungkan kinerja dan standar untuk karyawan yang telah ditetapkan, maka perusahaan akan melakukan proses penggajian dengan mempersiapkan data sesuai dengan catatan akuntansi biaya tenaga kerja. Untuk memperhitungkan data penggajian diperlukan dua tahap yaitu: (1) menghitung dan menyiapkan gaji, dan (2) mendistribusikan biaya gaji ke pesanan dan departemen. Dengan alur seperti pada bagan berikut ini:

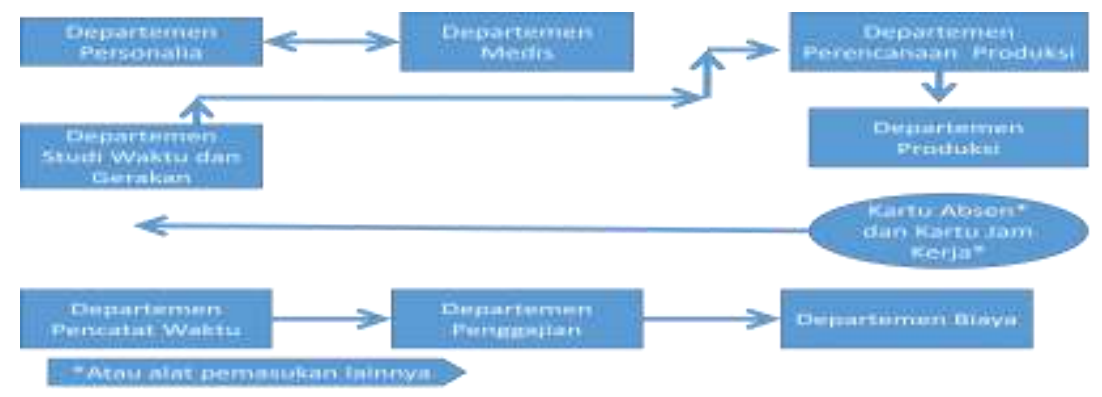

Secara garis besar tenaga kerja merupakan kontribusi kepada produksi yang memiliki hubungan langsung dengan tingkat produktivitas. Perbaikan produktivitas memerlukan manajemen sumber daya manusia yang lebih baik. Rencana Pemeberian Insentif mencerminkan imbalan berwujud atas kinerja yang diinginkan oleh pekerja. Rencana pemebrian insentif tersebut dibuat untuk individu, kelompok bahkan organisasi. Selanjutnya perencanaan atas kinerja karyawan diperluas lewat pemahan teori kurva belajar.

\section{Soal Diskusi}


1. Jelaskan definisi dari produktifitas.

2. Bagaimana efisiensi tenaga kerja dapat ditentukan dan diukur?

3. Apa tujuan dari rencana pemberian insentif bagi perusahaan?

4. Apakah yang dimaksud dengan rencana pemberian insentif organisasi/

\section{Soal Perhitungan}

Syafiq Mansyur adalah karyawan dari Moon Company menyerahkan data tenaga kerja untuk minggu pertama bulan Juni, sebagai berikut:

$\begin{array}{lrr} & \text { Unit } & \underline{\text { Jam }} \\ \text { Senin } & 250 & 8 \\ \text { Selasa } & 310 & 8 \\ \text { Rabu } & 310 & 8 \\ \text { Kamis } & 350 & 8 \\ \text { Jumat } & 260 & 8\end{array}$

Diminta: Buat jadwal yang menunjukkan pendapatan mingguan, tarif efektif perjam dan biaya tenaga kerja per unit, dengan asumsi rencana bonus seratus persen dengan upah dasar Rp 9.000,00 per jam dan tingkat produksi sebesar 30 unit per jam. Asumsikan bonus dihitung tiap minggu berdasarkan total produksi minggu tersebut. 


\section{BIAYA OVERHEAD PABRIK: PENENTUAN TARIF OVERHEAD}

Penggunaan tarif overhead pabrik telah dibahas dalam babbab sebelumnya untuk menentukan overhead sebelumnya untuk dibebankan ke dalam produk. Untuk lebih memperjelas mengenai overhead pabrik, maka didalam bab ini akan memberikan penjelasan tentang metode pembebanan overhead, klasifikasi dan akumulasi overhead aktual serta perhitungan dan pembebanan overhead pabrik yang dibebankan terlalu rendah maupun terlalu tinggi.

\section{Karakteristik Overhead Pabrik}

Secara umum definisi dari overhead pabrik adalah bahab baku tak langsung, biaya tenaga kerja tak langsung, serta seluruh biaya pabrik lainnya yang tidak mudah diidentifikasikan ataupun dibebankan secara langsung ke produk, pesanan, unit ataupun objek biaya tertentu. Istilah yang sering digunakan untuk mendefinisikan overhead pabrik adalah tanggungan pabrik, beban produksi, overhead produksi, beban pabrik, dan lain sebagainya.

Karakteristik yang dimiliki oleh overhead pabrik adalah jika produk yang akan dibebankan dengan jumlah wajag dan berkaitan dengan hubungan antara overhead pabrik dengan produk atau volume produksi. Tidak seperti bahan baku langsung dan tenaga kerja langsung, overhead adalah bagian yang tidak terlihat dari produk jadi. Tidak ada bukti permintaan bahan baku serta kartu jam kerja langsung. Akan teteapi overhead pabrik juga bagian penting 
dalam produksi dimana pada saat semakin meningkatnya otomasi pada operasi, maka nilai presentase overhead akan semakin naik, sedangkan presentase tenaga langsung akan menurun.

Selanjutnya untuk karakteristik kedua adalah overhead berubah sesuai dengan item-item yang berubah pada saat terdapat perubahan didalam volume produksi. Sehingga biaya overhead tetap nilainya akan relatif konstan tanpa memperhatikan perubahan pada tingkat ouput dalam rentang yang relevan. Besaran biaya overhead variabel proporsional terhadap perubahan dalam volume produksi. Pada saat volume berubah maka pola perilaku biaya overhead yang berbeda akan menyebabkan biaya produksi per unit berfluktuasi secara signifikan. Oleh karenanya dibutuhkan metode yang dapat menstabilkan jumlah overhead yang akan dibebankan dalam unit produksi.

Penggunaan Tarif Biaya Overhead yang Telah Ditentukan Sebelumnya

Pembebanan overhead dilakukam dalam suatu periode tertentu. Yang menjadi suatu pertamnyaan adalah bagaimana melakukan pembebanan tersebut untuk memungkinkan melakukan alokasi biaya overhead aktual ke dalam semua pekerjaan yang diselesaikan selama periode tersebut. Apabila volume produksi yang dilakukan dari bulan ke bulan besarannya tetap, maka besaran overhead akan tetap dan menghasilkan pembebanan yang wajar atas produksi pada setiap periode.

Akan tetapi secara umum terjadi variasi dari tiap periode bulanan sehingga terdapatan pembebanan overhead yang berbeda tiap bulannya. Sebagai contoh adanya perbaikan atas kerusakan alat 
yang mengakibatkan biaya overhead tinggi dan biaya produksi tinggi.Dengan kesulitan menelusuri, mengidentifikasi dan membebankan biaya overhead ke pesanan maupun produk, maka biaya overhead dialokasikan kepada seluruh pesanan atau unit produk. Tarif overhead yang telah ditentukan sebelumnya (predetermined overhead rate) akan memungkinkan alokasi biaya overhead yang konsisten dan wajar dalam setiap output unit. Baik untuk akumulasi biaya berdasarkan proses maupun akumulasi biaya berdasarkan pesanan menggunakan metode tarif overhead yang telah ditentukan adalah yang paling memungkinkan untuk memperhitungkasn biaya overhead sebagai informasi biaya produk yang dibutuhkan manajemen.

\section{Faktor-faktor Dalam Pertimbangan Pemilihan Tarif Biaya Overhead}

Tarif overhead memiliki jenis yang berbeda tidak hanya dari satu perusahaan dengan perusahaan lain, tapi juga diantara satu departemen, pusat biaya, divisi dalam satu perusahaan. Terdapat lima faktor yang mempengaruhi pemilihan tarif overhead. Faktorfaktor tersebut adalah:

\section{Dasar yang Dapat Digunakan}

Mengukur tarif overhead pabrik menggunakan dasar tarif overhead, dasar alokasi overhead, ataupun dasar. Dengan melakukan pemilihan atas dasar overhead ini menjadi penting apabila ingin menyediakan data biaya menggunakan suatu sistem. Tujuan utama dalam pemilihan dasar adalah dengan memastikan pembebanan overhead dengan proporsi yang wajar terhadap sumber daya pabrik tidak langsungyang digunakan pesanan, produk maupun pekerjaan yang dilakukan. 
Penentuan dasar yang digunakan sebaiknya berkaitan dengan fungsi dari biaya overhead yang akan dibebankan. Apabila overhead diwakili oleh biaya pengawasan dan tunjangan, maka dasar yang digunakan seperti jam tenaga kerja langsung ataupun biaya tenaga kerja langsung. Tetapi jika biaya yang digunakan berhubungan dengan pemakaian teknologi maka mempergunakan dasar jam mesin adalah yang paling sesuai.

Fungsi lain dari pemilihian dara pembebanan adalah untuk mempermudah pembebanan overhead, dimana pada saat terdapat dua dasar pembebanan tetapi memiliki hasil yang hampir sama maka akan dipakai dasar pembebanan yang paling mudah dan sederhana.

Output fisik merupakan dasar yang paling sederhana dalam pembebanan overhead pabrik. Dengan rumus

Estimasi overhead pabrik

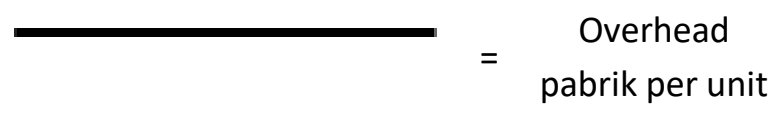

Estimasi unit produksi

Penggunaan dasar output fisik cukup menggambarkan apabila perusahaan hanya memproduksi satu jenis produk. Akan tetapi apabila perusahaan memproduksi beberapa jenis produk dasar pembebanan ini tidak bisa memberikan solusi pembebanan yang tepat. Namun bila produk yang berbeda tersebut berkaitan erat dan perbedaan hanya terletak pada perbedaan volume ataupun berat 
maka pembebanan overhead dapat menggunakan dasar berat, volume.

Biaya bahan baku langsung di masa lampau digunakan dengan hasil studi bahwa terdapat korelasi yang kuat antara biaya bahan baku langsung dengan overhead. Pembebanan dengan dasar biaya bahan baku langsung sangat mungkin dilakukan bila proses produksi terdiri dari penerimaan inspeksi, penyimpanan, pengambilan dan penanganan banyak lot bahan baku yang mahal. Dengan pembebanan tarif yang didasarkan atas biaya bahan baku akan lebih sesuai. Dengan cara membagi estimasi total overhead dengan estimasi total biaya bahan baku.

Estimasi overhead pabrik

\begin{tabular}{lc}
\hline$\times 100=$ & $\begin{array}{c}\text { Overhead pabrik } \\
\text { sebagai }\end{array}$ \\
$\begin{array}{l}\text { Estimasi biaya bahan } \\
\text { baku }\end{array}$ & $\begin{array}{c}\text { biaya bahan } \\
\text { baku langsung }\end{array}$
\end{tabular}

Penggunaan dasar biaya bahan baku ini sangat terbatas karena sangat tidak logis yang diakibatkan tidak adanya hubungan antara biaya bahan baku dengan penggunaan overhead dalam proses produksinya. 
Biaya tenaga kerja langsung untuk pembebanan overhead pabrik ke dalam pesanan atau produk mengharuskan estimasi overhead dibagi dengan estimasi biaya tenaga kerja langsung untuk menghitung presentase.

Estimasi overhead pabrik

Estimasi biaya tenaga kerja langsung
Overhead pabrik sebagai presentase dari biaya tenaga kerja langsung

Dengan menggunakan dasar biaya tenaga kerja langsung, pembebanan biaya overhead akan lebih mudah diperhitungkan, karena informasi data biaya tenaga kerja langsung telah tersedia. Apabila syarat utama dalam memperoleh informasi adalah pertimbangan biaya, maka dasar pembebanan menggunakan biaya tenaga kerja langsung dapat lebih diterima sebagai metode tercepat.

Metode dasar biaya tenaga kerja langsung akan tidak sesuai apabila dalam overhead pabrik mencakup biaya depresiasi mesin yang cukup mahal dan tidak memiliki hubungan dengan gaji tenaga kerja langsung.

Jam tenaga kerja langsung digunakan sebagai dasar pembebanan overhead yang didesain untuk mengatasi kelemahan dari penggunaan biaya tenaga kerja langsung. Tarif overhead diperhitungkan sebagai berikut: 
Metode pembebanan overhead dengan dasar jam tenaga kerja langsung ini membutuhkan akumulasi jam tenaga kerja langsung per pesanan atau pun produk, sehingga pencatatan waktu harus diatur agar dapat menyediakan data tambahan. Metode ini dapat digunakan jika proses produksi sebagian besar menggunakan tenaga kerja langsung, akan tetapi jika sebagian besar mempergunakan mesin maka penggunaan jam tenaga kerja langsung dinilai tidak wajar.

Dasar jam mesin dipergunakan sebagai metode pembebanan overhead pabrik pada saat mesin secara ekstensif dipergunakan dalam proses produksi. Waktu yang diperlukan dalam melakukan operasi yang identik oleh suatu mesin atau sekelompok mesin. Dengan penghitungan tarif sebagai berikut.

Estimasi overhead pabrik

Overhead

$x 100=$ pabrik per jam mesin

Estimasi jam mesin 
Penggunaan metode jam mesin memerlukan penambahan kerja staf untuk memastikan akumulasi pencatatan jam mesin dengan benar. Karena jika data jam mesin tidak diperlukan untuk pengukuran biaya maka karyawan pabrik, pengawas tidak akan melakukan pencatatan atas jam mesin.

\section{Pemilihan Tingkat Aktivitas}

Untuk memperhitungkan tarif overhead maka tingkat aktivitas yang dipilih akan sangat menentukan. Pembilang dari tarif overhead adalah biaya overhead dengan tingkat aktivitas tertentus. Dimana semakin besar tingkat aktivitas diasumsikan maka semakin rendah tarif overhead yang telah ditentukan sebelumnya. Tingkat aktivitas yang berbeda mencakup kapasitas teoritis, kapasistas praktis, kapasitas aktual yang diperkirakan dana kapasitas normal. Dengan penjelasan sebagai berikut.

Kapasitas Teoritis. Kapasitas teoritis dari suatu departemen, pabrik atau lainnya adalah kapasitas untuk memproduksi pada kecepatan penuh tanpa interupsi. Hal ini dicapai apabila departemen atau pabrik berproduksi pada tingkat 100\% dari kapasitas yang tyelah ditentukan. Melakukan operasi dalam tingkat penuh tidak mungkin dilakukan dalam periode bulanan, kuartal maupun tahunan. Karena ada terjadinya peluang perbaikan, kegagalan maupun hal lain yang tidak dapat diprediksikan.

Kapasitas Praktis merupakan kapasitas yang memberikan kelonggaran dari kapasitas teoritis karena adanya interupsi dari internal seperti perubahan pekerja, pemeliharaan preventif, perbaikan, persiapan, kegagalan, bahan baku yg tidak memuaskan, penundaan dalam pengantaran bahan baku, ketidakhadiran pekerja, 
hari minggu, cuti, dan lain sebagainya.Penurunan dari kapasitas teoritis sebesar $15 \%$ sampai dengan $25 \%$. Yaitu kapasitas sebesar $75 \%$ sampai dengan $85 \%$.

Kapasitas Aktual Yang Diperkirakan ini mengacu kepada jumlah output yang diperkirakan akan diproduksi selama periode tersebut. Dengan tingkat aktivitas ini sulit untuk menetapkan tarif yang dibedakan karena perbedaan tarif yang muncul.

Kapasitas Normal adalah kapasitas yang mengacu kepada rata-rata selama satu periode waktu yang cukup lama untuk meratakan fluktuasi. Dengan kapasitas normal ini digunakan untuk menstabilkan tarif overhead pabrik yang berfluktuasi saat fasilitas dipergunakan dalam tingkatan yang berbeda dan dalam periode yang berbeda.

\section{Biaya Overhead Aktual}

Penentuan dasar dan tingkay aktivitas, estimasi total overhead dan menghitung tarif overhead terjadi sebelum biaya aktual terjadi atau dicatat. Tujuan dasar dari akumulasi overhead pabrik adalah untuk menyediakan informasi sebagai pengendalian.

Overhead mencakup atas berbagai item yang diklasifikasikan dalam berbagai cara. Dimana setiap pabrik memiliki karakteristik masing-masing dengan membuat akun dan metode pengklasifikasiannya sendiri. Tanpa memperhatikan variasi yang ada, biaya overhead akan diikhtisarkan dalam akun pengendali overhead pabrik dalam buku besar, dengan rincian dalam akun buku pembantu overhead. 


\section{Biaya Overhead Dibebankan Terlalu Tinggi atau Terlalu Rendah}

Di akhir periode bulanan maupun tahunan overhead yang dibebankan dan overhead aktual akan dibandingkan dimana overhead pabrik aktual merupakan jum,lah biaya tidak langsung yang terjadi, sedangkan overhead pabrik dibebankan merupakan jumlah biaya yang dialokasikan ke output.

\section{Pembebanan Biaya Overhead}

Perhitungan tarif overhead diilustrasikan sebagai berikut: CheNil Product menggunakan estimasi overhead pabrik dan estimasi jam tenaga kerja langsung dengan tarif overhead jam tenaga kerja langsung $\mathrm{Rp} 15.000,00$. Jam tenaga kerja langsung aktual adalah sebesar 18.900 dan biaya overhead pabrik aktual sebesar Rp. 292.000.000,00 Overhead pabrik yang dibabankan dalam periode ini sebesar $18.900 \times$ Rp 15.000,00 = Rp 283.500.000,00. Dengan ayat jurnal:

$$
\begin{aligned}
& \text { Barang DIm Proses } \quad \text { Rp 283.500.000,00 } \\
& \begin{array}{ll}
\text { BOP dibebankan(AFO) } & \text { RP. } 283.500 .000,00
\end{array}
\end{aligned}
$$

Akun overhead pabrik dibebankan kemudian ditutup ke akun pengendali overhead di akhir tahun, dengan jurnal: 
Setelah seluruh jurnal dimasukkan kemudian akun pengendali overhead akan tampak sebagai berikut

Pengendali Overhead Pabrik

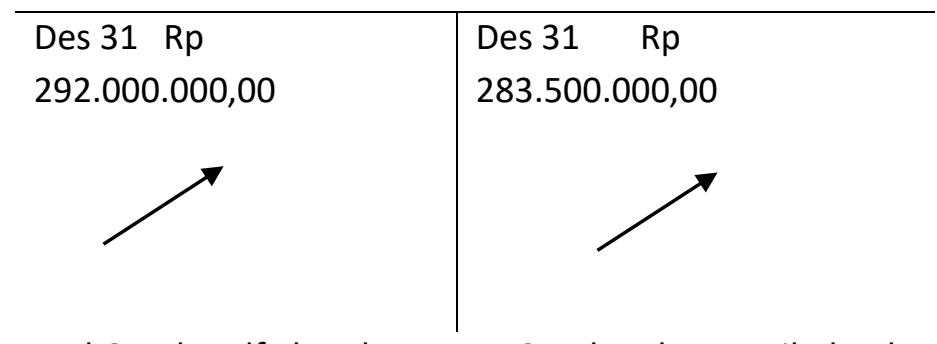

Total Overheadf aktual

Overhead yang Dibebankan

Dari akun pengendali overhead pabrik tersebut terdapat selisih sebesar Rp 8.500.000,00 dimana overhead pabrik dibebankan lebih rendah dibandingkan dengan biaya overhead pabrik aktual. Perbedaan ini akan dilakukan analisis kenapa overhead pabrik dibebankan terlalu rendah.

Dengan adanya pembebanan terlalu tinggi ataupun terlalu rendah tidak terlalu signifikan maka jumlah tersebut ditutup pada ikhtisar laba rugi atau ke Harag PokoK Penjualan sebagaio biaya periodik.Dengan jurnal sebagai berikut: 


\section{Soal Diskusi}

1. Apa sajakah yang termasuk dalam overhead pabrik?

2. Faktor-faktor apa yang sebaiknya digunakan dalam pemilihan dasar pembebanan overhead pabrik.

3. Apa perbedaan antara Kapasitas Teoritis, Kapasitas, Praktis, Kapasitas Aktual, Kapasitas Normal?

4. Apabila akun pengendali overhead pabrik memiliki saldo kredit di akhir periode, apakah pembebanan overhead pabrik terlalu rendah atau terlalu tinggi?

\section{Soal Perhitungan}

1. PT Manggala menganggarkan overhead pabrik sebesar Rp 255.000.000,00 untuk periode Juni bagi Departemen X, berdasarkan volume yang dianggarkan sebesar 50.000 jam mesin. Pada akhir periode, overhead pabrik aktual adalah sebesar Rp 281.000.000,00 dan jam mesin aktual adalah sebesar 52.500. Hitunglah jumlah overhead yang dibebankan 
apakah terlalu tinggi atau terlalu rendah untuk periode tersebut. 


\section{DAFTAR PUSTAKA}

A.Dunia, Firdaus dan Wasilah Abdullah. 2009. Akuntansi Biaya.Jakarta: Salemba Empat.

Bustami, Bastian dan Nurlela. 2009. Akuntansi Biaya. Edisi Pertama. Jakarta: Mitra Wacana Media.

Carter, Wiliam K. 2009. Akuntansi Biaya. Edisi 14. Jakarta: Salemba Empat.

Carter, William K danUsry, Milton F. 2004. Akuntansi Biaya. Diterjemahkan oleh Krista. Edisi Ketiga belas. BukuSatu. Jakarta: Salemba Empat.

Ikatan Akuntansi Indonesia.2009.Standar Akuntansi Keuangan. Jakarta: Salemba Empat

Mulyadi. 2012. Akuntansi Biaya. Edisi ke-5. Cetakan Kesebelas. Yogyakarta: STIM YKPN.

Mulyadi. 2009. Akuntansi Biaya. Edisike 5. Yogyakarta: STIE YKPN.

Mulyadi 2007. Akuntansi Biaya. Yogyakarta: UPP Akademi Manajemen Perusahaan YKKPN. 


\section{BIODATA PENULIS}

Santi Rahma Dewi, SE., M.Ak. dilahirkan di Magetan, 20 Juli 1980. Pada tahun 2004, penulis mendapatkan gelar Sarjana Ekonomi dari Universitas Pembangunan Nasional "Veteran" Jawa Timur. Penulis melanjutkan magister akuntansi konsentrasi akuntansi manajemen di Universitas Pembangunan Nasional "Veteran" Jawa Timur. Ditahun 2014 penulis secara resmi mendapatkan gelar M.Ak. Penulis mengawali karirnya sebagai Dosen di prodi Akuntansi Universitas Muhaammdiyah Sidoarjo sejak tahun 2012. Sebelum menjadi dosen penulis pernah bekerja di Bank BUMN terbesar di Indonesia. Beberapa penelitian yang pernah dilakukan oleh penulis adalah tentang sektor publik, green accounting, dan good corporate governance.

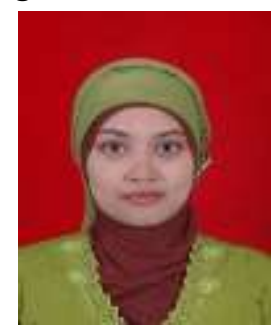

